\title{
NEVADA NATIONAL SECURITY SITE 2011 WASTE MANAGEMENT MONITORING REPORT AREA 3 AND AREA 5 RADIOACTIVE WASTE MANAGEMENT SITES
}

July 2012

Prepared for:

U.S. Department of Energy

National Nuclear Security Administration Nevada Site Office

Prepared by:

National Security Technologies, LLC Las Vegas, Nevada 


\section{DISCLAIMER}

Reference herein to any specific commercial product, process, or service by trade name, trademark, manufacturer, or otherwise does not necessarily constitute or imply its endorsement, recommendation, or favoring by the United States Government or any agency thereof.

Available for sale to the public, in paper, from:

U.S. Department of Commerce

National Technical Information Service

5301 Shawnee Road

Alexandria, VA 22312

Phone: 800.553.6847

Fax: 703.605.6900

E-mail: orders@ntis.gov

Online Ordering: http://www.ntis.gov/help/ordermethods.aspx

Available electronically at http://www.osti.gov/bridge

Available for a processing fee to the U.S. Department of Energy and its contractors, in paper, from:

U.S. Department of Energy

Office of Scientific and Technical Information

P.O. Box 62

Oak Ridge, TN 37831-0062

Phone: 865.576.8401

Fax: 865.576.5728 


\title{
NEVADA NATIONAL SECURITY SITE 2011 WASTE MANAGEMENT MONITORING REPORT AREA 3 AND AREA 5 RADIOACTIVE WASTE MANAGEMENT SITES
}

\author{
July 2012 \\ Prepared for: \\ U.S. Department of Energy \\ National Nuclear Security Administration \\ Nevada Site Office \\ Prepared by: \\ National Security Technologies, LLC \\ Las Vegas, Nevada
}


THIS PAGE INTENTIONALLY LEFT BLANK 


\section{EXECUTIVE SUMMARY}

Environmental monitoring data are collected at and around the Area 3 and Area 5 Radioactive Waste Management Sites (RWMSs) at the Nevada National Security Site (NNSS). These data are associated with radiation exposure, air, groundwater, meteorology, and vadose zone. This report summarizes the 2011 environmental data to provide an overall evaluation of RWMS performance and to support environmental compliance and performance assessment (PA) activities. Some of these data (e.g., radiation exposure, air, and groundwater) are presented in other reports (National Security Technologies, LLC, 2011; 2012a; 2012b).

Direct radiation monitoring data indicate exposure levels at the RWMSs are within the range of background levels measured at the NNSS. Slightly elevated exposure levels outside the Area 3 RWMS are attributed to nearby historical aboveground nuclear weapons tests. Air monitoring data show tritium concentrations in water vapor and americium and plutonium concentrations in air particles are only slightly above detection limits and background levels. The measured levels of radionuclides in air particulates and moisture are below derived concentration guides for these radionuclides. During the last 2 weeks of March 2011, gamma spectroscopy results for air particles showed measurable activities of iodine-131 $\left({ }^{131} \mathrm{I}\right)$, cesium-134 $\left({ }^{134} \mathrm{Cs}\right)$, and cesium-137 $\left({ }^{137} \mathrm{Cs}\right)$. These results are attributed to the release of fission products from the damaged Fukushima Daiichi power plant in Japan. The remaining gamma spectroscopy results for air particulates collected at the Area 3 and Area 5 RWMS were below minimum detectable concentrations. Groundwater monitoring data indicate the groundwater in the uppermost aquifer beneath the Area 5 RWMS is not impacted by RWMS operations. Results of groundwater analysis from wells around the Area 5 RWMS were all below established investigation levels.

The 86.3 millimeters $(\mathrm{mm})$ (3.40 inches [in.]) of precipitation at the Area 3 RWMS during 2011 is $44 \%$ below the average of $154.1 \mathrm{~mm}$ (6.07 in.), and the $64.8 \mathrm{~mm}$ (2.55 in.) of precipitation at the Area 5 RWMS during 2011 is $47 \%$ below the average of $122.4 \mathrm{~mm}$ (4.82 in.). Water balance measurements indicate that evapotranspiration from the vegetated weighing lysimeter dries the soil and prevents downward percolation of precipitation more effectively than evaporation from the bare-soil weighing lysimeter. Automated vadose zone monitoring on Area 5 RWMS operational waste covers was not done during 2011 due to construction of the final evapotranspiration cover at these monitoring locations. Moisture from precipitation did not percolate below 122 centimeters (4 feet) in the vegetated final mono-layer cover on the U-3ax/bl disposal unit at the Area 3 RWMS before being removed by evapotranspiration. During 2011, there was no drainage through 2.4 meters ( $8 \mathrm{feet}$ ) of soil from the Area 3 drainage lysimeters that received only natural precipitation. Ten percent of the applied precipitation and irrigation drained from the bare-soil drainage lysimeter that received 3 times natural precipitation.

All 2011 monitoring data indicate that the Area 3 and Area 5 RWMSs are performing within expectations of the model and parameter assumptions for the facility PAs. 
THIS PAGE INTENTIONALLY LEFT BLANK 


\section{TABLE OF CONTENTS}

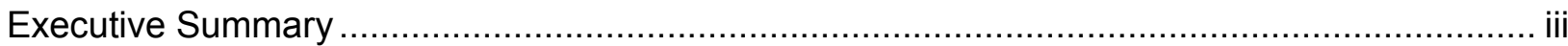

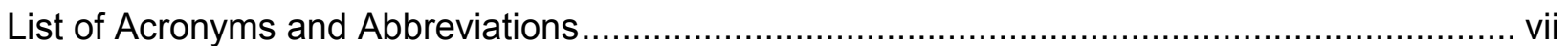

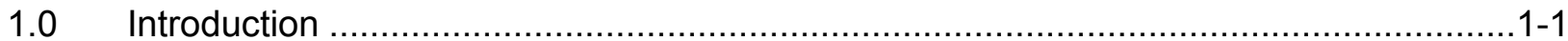

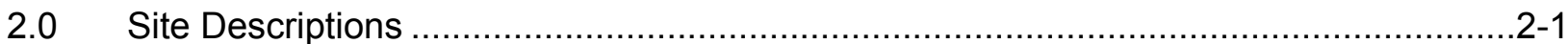

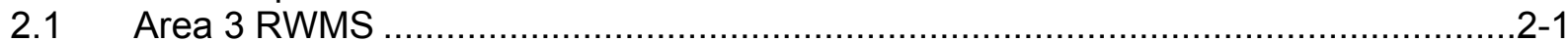

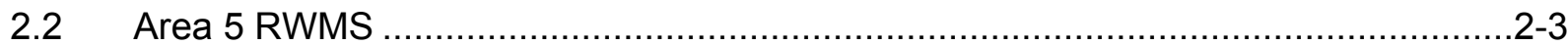

2.3 Hydrologic Conceptual Model of the Area 3 and Area 5 RWMS .............................2-3

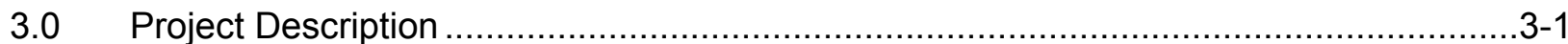

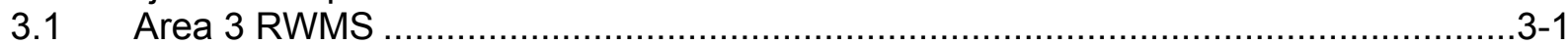

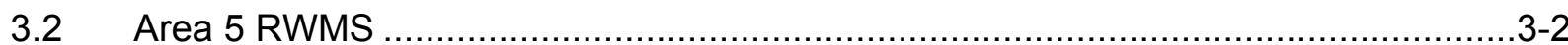

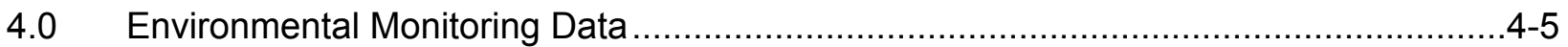

4.1 Types of Environmental Monitoring Data .................................................... $4-5$

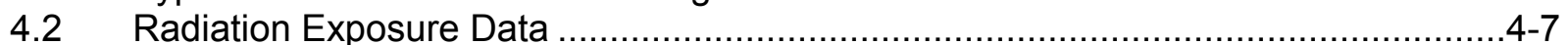

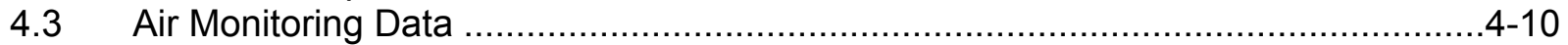

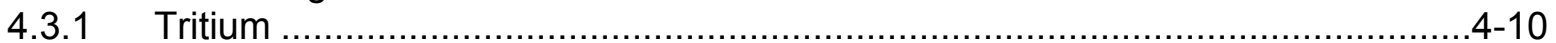

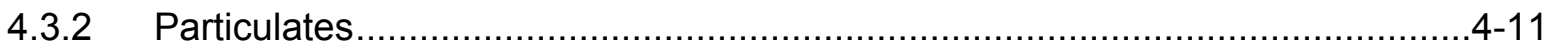

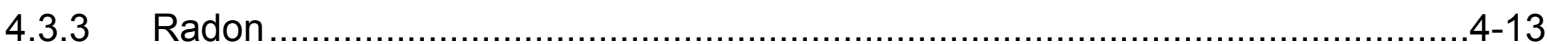

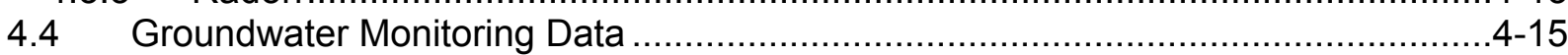

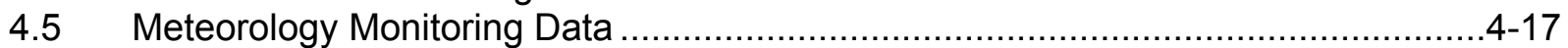

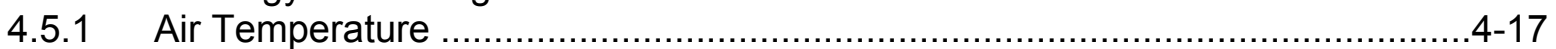

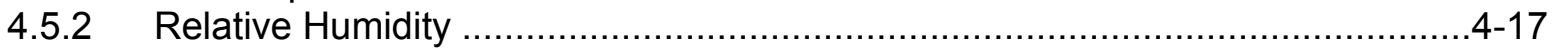

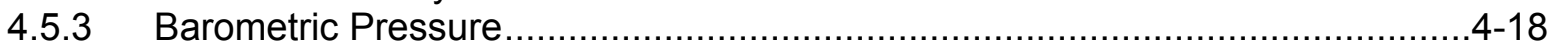

4.5.4 Wind Speed and Wind Direction .........................................................

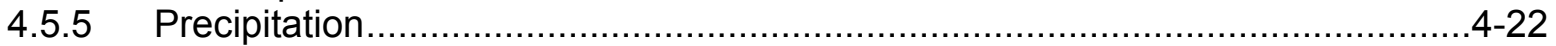

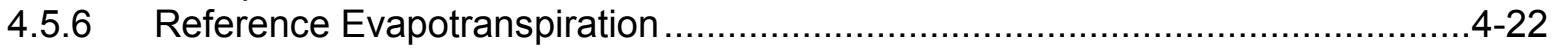

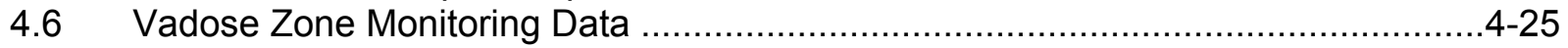

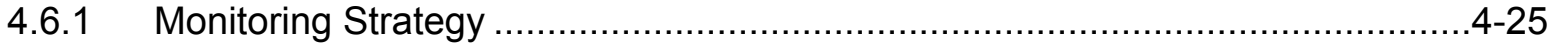

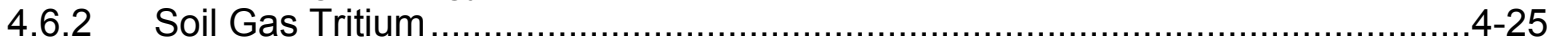

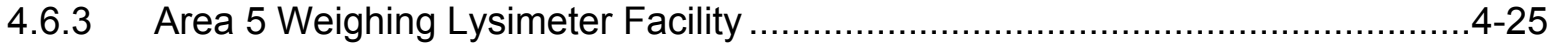

4.6.4 Automated Waste Cover Monitoring System ..............................................4-28

4.6.5 Area 3 Drainage Lysimeter Facility ............................................................

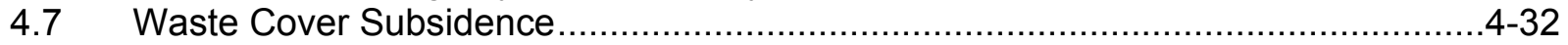

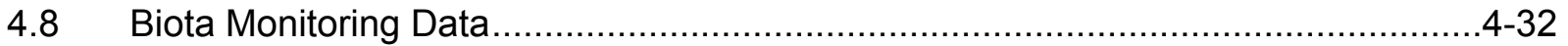

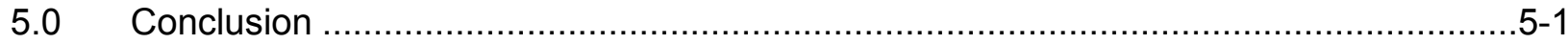

6.0 References

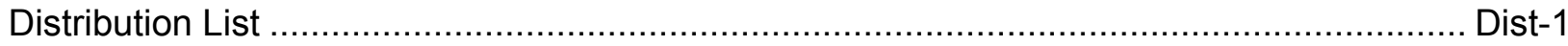




\section{LIST OF FIGURES}

Figure 2-1. Location of the Area 3 and Area 5 RWMSs..................................................2-2

Figure 2-2. Vadose Zone Conceptual Models of the Area 3 and Area 5 RWMSs ....................2-4

Figure 3-1. Monitoring Locations at the Area 3 RWMS .................................................

Figure 3-2. Monitoring Locations at the Area 5 RWMS ................................................ $3-4$

Figure 4-1. Annual Radiation Exposure Rates at the Area 3 RWMS during 2011..................4-8

Figure 4-2. Quarterly Average Daily Exposure Rates at the Area 3 RWMS and NNSS

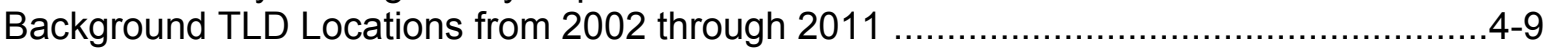

Figure 4-3. Quarterly Average Daily Exposure Rates at the Area 5 RWMS and NNSS

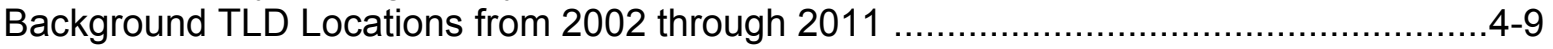

Figure 4-4. Tritium Concentration in Air at the Area 3 and Area 5 RWMSs during 2011 ........4-10

Figure 4-5. Concentration of ${ }^{241} \mathrm{Am}$ in Air at the Area 3 and Area 5 RWMSs during 2011......4-11

Figure 4-6. Concentration of ${ }^{238} \mathrm{Pu}$ in Air at the Area 5 and Area $3 \mathrm{RWMSs}$ during $2011 \ldots \ldots . .4-12$

Figure 4-7. Concentration of ${ }^{239+240} \mathrm{Pu}$ in Air at the Area 5 and Area 3 RWMSs during 2011 ..4-12

Figure 4-8. Concentration of ${ }^{137} \mathrm{Cs}$ in Air at the Area 3 and Area 5 RWMS during $2011 \ldots \ldots . . .4-13$

Figure 4-9. Radon Flux Measurement Location in Area 3 ..........................................4-14

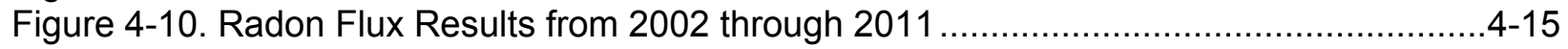

Figure 4-11. Groundwater Elevation at the Three Area 5 RWMS Pilot Wells ......................4-16

Figure 4-12. Daily Maximum and Minimum Temperature at the Area 3 and Area 5 RWMSs..4-17

Figure 4-13. Daily Average Relative Humidity at the Area 3 and Area 5 RWMSs ................4-18

Figure 4-14. Average Barometric Pressure at the Area 3 and Area 5 RWMSs ....................4-19

Figure 4-15. Daily $3 \mathrm{~m}$ Wind Speed at the Area 3 RWMS .............................................4-20

Figure 4-16. Daily $3 \mathrm{~m}$ Wind Speed at the Area 5 RWMS ............................................4-20

Figure 4-17. Wind Rose Diagram for the Area 3 RWMS ............................................... $4-21$

Figure 4-18. Wind Rose Diagram for the Area 5 RWMS ..............................................4-21

Figure 4-19 Daily Precipitation at the Area 3 RWMS ....................................................... $4-23$

Figure 4-20 Daily Precipitation at the Area 5 RWMS ...................................................4-23

Figure 4-21. Historical Precipitation Record for the Buster-Jangle $Y$ and the Area 3 RWMS..4-24

Figure 4-22. Historical Precipitation Record for Well 5B and Area 5 RWMS .......................4-24

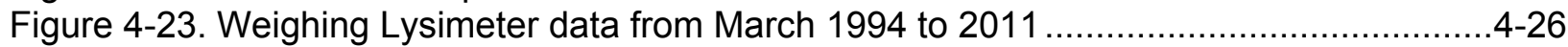

Figure 4-24. Precipitation, ET, E, and Storage for the Weighing Lysimeters during 2011 ......4-27

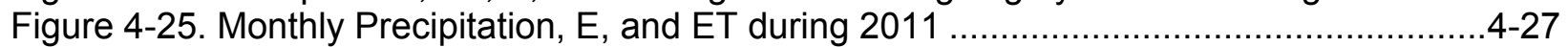

Figure 4-26. Soil Water Content in the U-3ax/bl Cover..............................................4-29

Figure 4-27. Cumulative Drainage from the Drainage Lysimeters ...................................4-31

Figure 4-28. Soil Water Storage in the Drainage Lysimeters ...........................................4-32

\section{LIST OF TABLES}

Table 4-1. Investigation Levels and Results from 2011 Groundwater Monitoring..................4-16

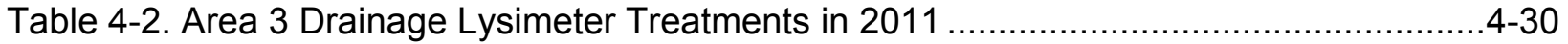

Table 4-3. Area 3 Drainage Lysimeter Percent Cover ...................................................4-31 


\section{LIST OF ACRONYMS AND ABBREVIATIONS}

AGL

above ground level

Am

americium

AMSL

above mean sea level

ARL/SORD

Air Resources Laboratory, Special Operations and Research Division

BJY

Buster-Jangle $Y$

BN

Bechtel Nevada

${ }^{\circ} \mathrm{C}$

degrees Celsius

C

carbon

CAU

CFR

$\mathrm{cm}$

Cs

Corrective Action Unit

Code of Federal Regulations

centimeter(s)

cesium

DCG derived concentration guide

DOE U.S. Department of Energy

E evaporation

EPA U.S. Environmental Protection Agency

ET evapotranspiration

$\mathrm{ET}_{\text {ref }} \quad$ reference evapotranspiration

${ }^{\circ} \mathrm{F} \quad$ degrees Fahrenheit

$\mathrm{ft} \quad$ foot; feet

$\mathrm{ft}^{3} \quad$ cubic feet

GCD greater confinement disposal

IL investigation level

in. inch(es)

km kilometer(s)

$\mathrm{kPa} \quad$ kilopascal(s)

LLW low-level waste

$\mu \mathrm{g} / \mathrm{L} \quad$ microgram(s) per liter

$\mathrm{m} \quad$ meter(s)

$\mathrm{m}^{3} \quad$ cubic meter(s)

$\mathrm{m} / \mathrm{s} \quad$ meter(s) per second

MDC minimum detectable concentration

MEDA Meteorological Data Acquisition

$\mathrm{mg} / \mathrm{L} \quad$ milligram(s) per liter

$\mathrm{mi} \quad$ mile(s)

$\mathrm{mm} \quad$ millimeter(s)

$\mathrm{mmhos} / \mathrm{cm}$ millimho(s) per centimeter

$\mathrm{mph} \quad$ mile(s) per hour 


\begin{tabular}{|c|c|}
\hline $\begin{array}{l}\mathrm{mR} \\
\mathrm{mR} / \mathrm{day} \\
\mathrm{mR} / \mathrm{yr} \\
\text { mrem } \\
\text { mrem/yr }\end{array}$ & $\begin{array}{l}\text { milliroentgen(s) } \\
\text { milliroentgen(s) per day } \\
\text { milliroentgen(s) per year } \\
\text { millirem(s) } \\
\text { millirem(s) per year }\end{array}$ \\
\hline NNSS & Nevada National Security Site \\
\hline NSTec & National Security Technologies, LLC \\
\hline $\begin{array}{l}\mathrm{PA} \\
\mathrm{pCi} / \mathrm{L} \\
\mathrm{pCi} / \mathrm{m}^{3} \\
\mathrm{pCi} / \mathrm{m}^{2} / \mathrm{s} \\
\mathrm{PSI} \\
\mathrm{PST} \\
\mathrm{Pu}\end{array}$ & $\begin{array}{l}\text { Performance Assessment } \\
\text { picocurie(s) per liter } \\
\text { picocurie(s) per cubic meter } \\
\text { picocurie(s) per square meter per second } \\
\text { pound(s) per square inch } \\
\text { pacific standard time } \\
\text { plutonium }\end{array}$ \\
\hline $\begin{array}{l}\text { RREMP } \\
\text { RWMS }\end{array}$ & $\begin{array}{l}\text { Routine Radiological Environmental Monitoring Plan } \\
\text { Radioactive Waste Management Site }\end{array}$ \\
\hline $\begin{array}{l}\mathrm{SC} \\
\mathrm{Sr}\end{array}$ & $\begin{array}{l}\text { specific conductance } \\
\text { strontium }\end{array}$ \\
\hline $\begin{array}{l}\text { TDR } \\
\text { TC } \\
\text { TLD } \\
\text { TOC } \\
\text { TOX }\end{array}$ & $\begin{array}{l}\text { time-domain reflectometry } \\
\text { technetium } \\
\text { thermoluminescent dosimeter } \\
\text { total organic carbon } \\
\text { total organic halides }\end{array}$ \\
\hline & tric water content \\
\hline
\end{tabular}




\subsection{INTRODUCTION}

This document summarizes the calendar year 2011 waste management environmental monitoring data for the Area 3 and Area 5 Radioactive Waste Management Sites (RWMSs). Characterization reports for the Area 3 RWMS (National Security Technologies, LLC [NSTec], 2007) and the Area 5 RWMS (Bechtel Nevada [BN], 2006) provide descriptions of each RWMS including location, setting, waste disposal operations, and monitoring programs. These reports also provide brief summaries of characterization and monitoring data. The Integrated Closure and Monitoring Plan for the Area 3 and Area 5 Radioactive Waste Management Sites at the Nevada Test Site (BN, 2005c) and the Closure Plan for the Area 5 Radioactive Waste Management Site at the Nevada Test Site (NSTec, 2008) identify the regulatory requirements and describe the intended approach for closing and monitoring the RWMSs after waste disposal is finished. The southern portion of the Area 5 RWMS was closed during 2011. This area is called the 92-Acre Area. Construction of the final engineered evapotranspiration (ET) cover for the 92-Acre Area began in January 2011, and final seeding of this cover with native vegetation was completed in December 2011 (NNSA/NSO, 2010; 2012).

This report summarizes environmental data, as briefly defined below:

- Direct radiation monitoring conducted to confirm that RWMS activities do not result in significant exposure above background levels

- Air monitoring conducted to confirm that RWMS activities do not result in significant radionuclide concentrations above background levels and confirm compliance with National Emission Standards for Hazardous Air Pollutants

- Groundwater monitoring conducted, as required by U.S. Environmental Protection Agency (EPA) regulations and U.S. Department of Energy (DOE) orders, to assess the water quality of the aquifer beneath the Area 5 RWMS and to confirm that Area 5 RWMS activities are not affecting the aquifer

- Vadose zone monitoring conducted to assess the water balance at the RWMSs, confirm the assumptions made in performance assessments (PAs) (including no downward pathway), and evaluate the performance of operational monolayer-evapotranspirative waste covers

- Biota monitoring for tritium and other radionuclides conducted to evaluate the upward pathway through the waste covers

Soil-gas monitoring at Greater Confinement Disposal (GCD) borehole GCD-05 was permanently discontinued after the 2010 measurements because this borehole was buried below the final 92-Acre Area ET cover. Automated vadose monitoring on the operational covers at the Area 5 RWMS was temporarily discontinued during construction of the ET cover. New vadose zone moisture sensors were installed in the final ET cover during October 2011. A total of 64 subsidence monuments were installed in the ET cover and will be monitored annually.

These data are collected by NSTec, as required by various DOE orders and requirements from the Code of Federal Regulations (CFR). For a detailed description of these regulatory drivers, refer to the Integrated Closure and Monitoring Plan (BN, 2005c) and the Area 5 RWMS Closure Plan (NSTec, 2008). These regulatory drivers exist to mitigate risk to the public and environment and include the following:

- DOE O 435.1, "Radioactive Waste Management" 
- DOE O 450.1A, "Environmental Protection Program"

- DOE O 5400.5, "Radiation Protection of the Public and the Environment"

- 40 CFR 61, "National Emission Standards for Hazardous Air Pollutants"

- 40 CFR 264, "Standards for Owners and Operators of Hazardous Waste Treatment, Storage, and Disposal Facilities"

- 40 CFR 265, "Interim Status Standards for Owners and Operators of Hazardous Waste Treatment, Storage, and Disposal Facilities"

Environmental monitoring data are collected and analyzed as described in Quality Assurance, Analysis, and Sampling Plans, which can be found in the Nevada Test Site Routine Radiological Environmental Monitoring Plan (RREMP) (BN, 2003). The RREMP was written with a Data Quality Objectives-driven process to identify what and how technically defensible environmental monitoring data are collected. 


\subsection{SITE DESCRIPTIONS}

\subsection{AREA 3 RWMS}

The Area 3 RWMS is located on Yucca Flat within the Nevada National Security Site (NNSS). Yucca Flat is an elongated, sediment-filled basin that trends roughly north-south; the long axis extends approximately 27 kilometers $(\mathrm{km})$ (17 miles [mi]), and the short axis extends approximately $16 \mathrm{~km}$ (10 mi). Yucca Flat is bound by Quartzite Ridge and Rainier Mesa on the north, the Halfpint Range on the east, the Massachusetts Mountains and CP Hills on the south, and Mine Mountain and the Eleana Range on the west (Figure 2-1). The Yucca Flat basin slopes from the north at an elevation of approximately 1,402 meters $(\mathrm{m})(4,600$ feet [ft]) above mean sea level (AMSL) to the south toward Yucca playa, with the lowest part of the basin at an elevation of approximately 1,189 $\mathrm{m}(3,900 \mathrm{ft})$ AMSL. The Area $3 \mathrm{RWMS}$ elevation is 1,223 $\mathrm{m}$ $(4,012 \mathrm{ft})$. Yucca Flat was one of several primary underground nuclear test areas, and much of the length of the valley is marked with subsidence craters (NSTec, 2007).

The unsaturated zone at the Area 3 RWMS is estimated to be approximately $488 \mathrm{~m}(1,600 \mathrm{ft})$ thick (BN, 1998), and the water table is assumed to occur in Tertiary tuff. The alluvium thickness is estimated between 370 and $460 \mathrm{~m}$ (1,200 and 1,500 ft) (BN, 2005b).

Based on a 21-year record from 1981 to 2001 at location Buster-Jangle Y (BJY) $(4.5 \mathrm{~km}$ [2.8 mi] northwest of the Area 3 RWMS), typical daily air temperatures vary from -3 degrees Celsius $\left({ }^{\circ} \mathrm{C}\right)$ (26 degrees Fahrenheit [ $\left.\left.{ }^{\circ} \mathrm{F}\right]\right)$ to $12^{\circ} \mathrm{C}\left(54^{\circ} \mathrm{F}\right)$ during the winter months of December, January, and February and from $14^{\circ} \mathrm{C}\left(57^{\circ} \mathrm{F}\right)$ to $34^{\circ} \mathrm{C}\left(94^{\circ} \mathrm{F}\right)$ during the summer months of June, July, and August. The average winter temperature is $4^{\circ} \mathrm{C}\left(40^{\circ} \mathrm{F}\right)$ and the average summer temperature is $24^{\circ} \mathrm{C}\left(75^{\circ} \mathrm{F}\right)$. During this 21 -year period, the maximum observed temperature was $43.3^{\circ} \mathrm{C}\left(110^{\circ} \mathrm{F}\right)$ and the minimum observed temperature was $-20^{\circ} \mathrm{C}\left(-4^{\circ} \mathrm{F}\right)$. Average relative humidity is $53 \%$ at $4: 00$ pacific standard time (PST), $28 \%$ at $10: 00$ PST, $26 \%$ at 16:00 PST, and $45 \%$ at 22:00 PST. January has the highest relative humidity of $67 \%$ at 4:00 PST, 42\% at 10:00 PST, 43\% at 16:00 PST, and $62 \%$ at 22:00 PST. July has the lowest relative humidity of $40 \%$ at $4: 00$ PST, $19 \%$ at $10: 00$ PST, $17 \%$ at $16: 00$ PST, and $30 \%$ at $22: 00$ PST. The maximum wind gust observed at BJY during this 21-year period was 29.3 meters per second (m/s) (65.6 miles per hour [mph]) in 1987 (Soule, 2006). The average annual precipitation at BJY during the 51-year period from 1961 through 2011 is 160.5 millimeters $(\mathrm{mm})$ (6.32 inches [in.]). Typically low intensity, longer duration storms occur during the winter, and thunderstorms occur during the late summer. February has the most precipitation, and June has the least precipitation (Air Resources Laboratory, Special Operations and Research Division [ARL/SORD], 2012). Annual reference evapotranspiration ( $\left.E T_{\text {ref }}\right)$ at the Area 3 RWMS, calculated using local meteorology data, is approximately 10 times the annual average precipitation (Desotell et al., 2007). 


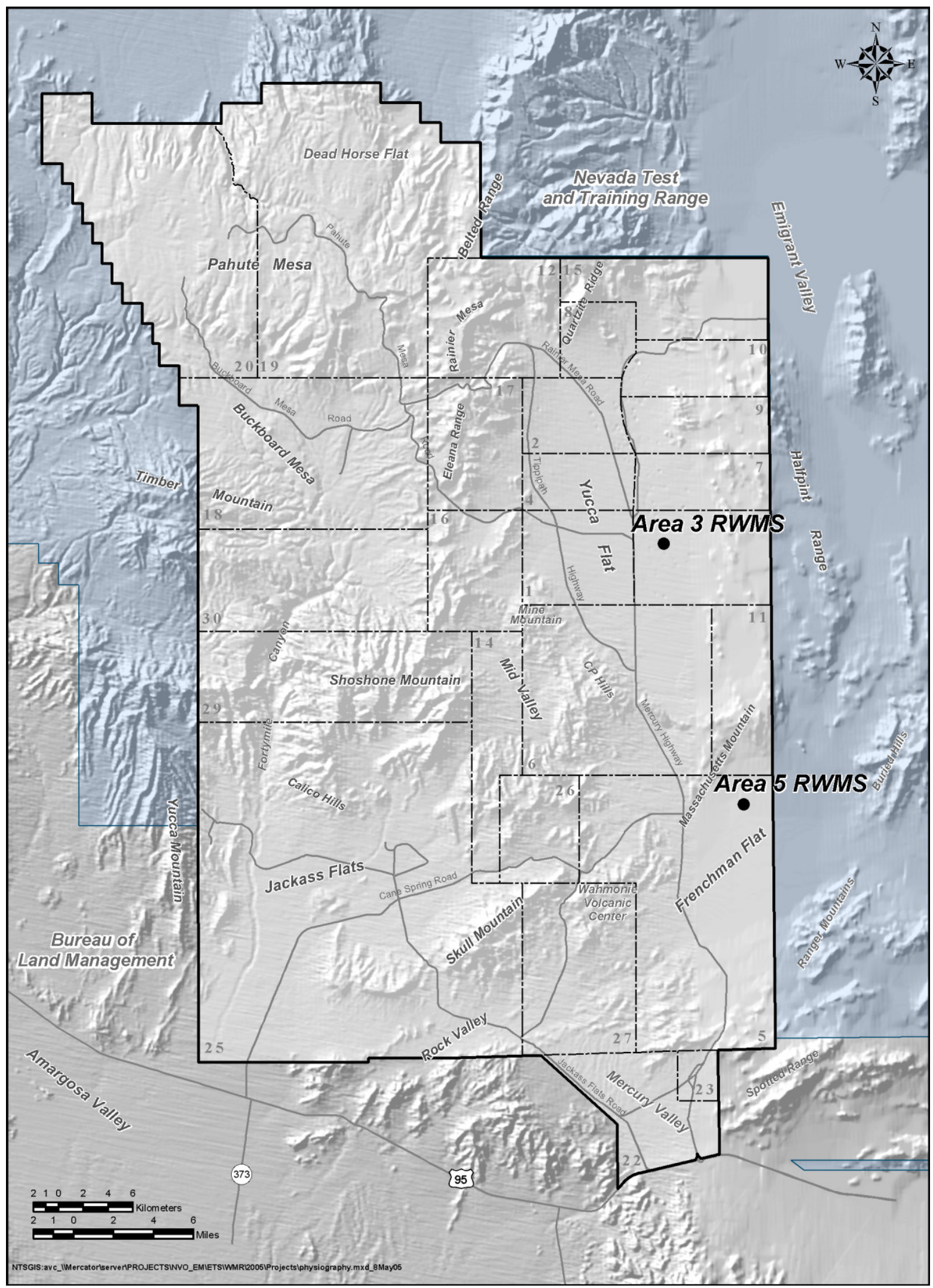

Figure 2-1. Location of the Area 3 and Area 5 RWMSs 


\subsection{AREA 5 RWMS}

The Area 5 RWMS is located on northern Frenchman Flat at the juncture of three coalescing alluvial fan piedmonts (Snyder et al., 1995). Frenchman Flat is a closed intermontane basin located in the southeastern portion of the NNSS. Frenchman Flat is bound by the Massachusetts Mountains and the Halfpint Range on the north, the Buried Hills on the east, the Spotted Range on the south, and the Wahmonie Volcanic Center on the west (Figure 2-1). The valley floor slopes gently toward a central playa (BN, 2006). Ground surface elevations range

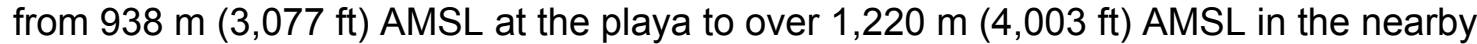
surrounding mountains. The Area 5 RWMS elevation is $962 \mathrm{~m}(3,156 \mathrm{ft})$.

The thickness of the unsaturated zone at the Area 5 RWMS is $235.9 \mathrm{~m}(773.8 \mathrm{ft})$ at the southeast corner of the RWMS (Well UE5PW-1), $256.5 \mathrm{~m}(841.5 \mathrm{ft}$ ) at the northeast corner (Well UE5PW-2), and $271.6 \mathrm{~m}$ (890.9 ft) to the northwest of the RWMS (Well UE5PW-3). Wells UE5PW-1 and UE5PW-2 penetrate only alluvium, while Well UE5PW-3 encounters

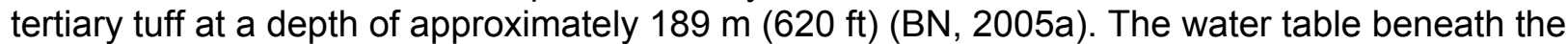
Area 5 RWMS is extremely flat with flow velocities of less than $0.1 \mathrm{~m} /$ year $(0.33 \mathrm{ft} / \mathrm{year})$. The

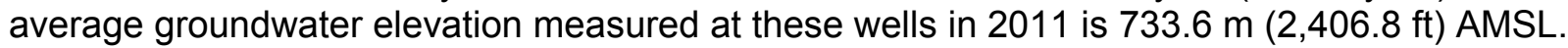

Based on a 21-year record from 1981 to 2001 at location Well $5 \mathrm{~B}(6.4 \mathrm{~km}$ [4 mi] south of the Area $5 \mathrm{RWMS})$, typical daily air temperatures vary from $-4^{\circ} \mathrm{C}\left(25^{\circ} \mathrm{F}\right)$ to $14^{\circ} \mathrm{C}\left(57^{\circ} \mathrm{F}\right)$ during the winter months of December, January, and February and from $15^{\circ} \mathrm{C}\left(59^{\circ} \mathrm{F}\right)$ to $37^{\circ} \mathrm{C}\left(99^{\circ} \mathrm{F}\right)$ during the summer months of June, July, and August. The average winter temperature is $5^{\circ} \mathrm{C}\left(41^{\circ} \mathrm{F}\right)$ and the average summer temperature is $26^{\circ} \mathrm{C}\left(79^{\circ} \mathrm{F}\right)$. During this 21 -year period, the maximum observed temperature was $46^{\circ} \mathrm{C}\left(115^{\circ} \mathrm{F}\right)$ and the minimum observed temperature was $-21^{\circ} \mathrm{C}$ $\left(-6^{\circ} \mathrm{F}\right)$. Average relative humidity is $46 \%$ at $4: 00 \mathrm{PST}, 25 \%$ at $10: 00 \mathrm{PST}, 20 \%$ at $16: 00 \mathrm{PST}$, and $37 \%$ at $22: 00$ PST. January has the highest relative humidity of $65 \%$ at $4: 00$ PST, $46 \%$ at 10:00 PST, $34 \%$ at 16:00 PST, and $58 \%$ at 22:00 PST. June has the lowest relative humidity of $32 \%$ at $4: 00$ PST, $14 \%$ at $10: 00$ PST, $12 \%$ at $16: 00$ PST, and $21 \%$ at $22: 00$ PST. The maximum wind gust observed at Well 5B during this 21-year period was $29.8 \mathrm{~m} / \mathrm{s}(66.7 \mathrm{mph})$ in 1988 (Soule, 2006). The average annual precipitation at Well 5B during the 49-year period from 1963 through 2011 is $122.4 \mathrm{~mm}$ (4.82 in.). Typically low intensity, longer duration storms occur during the winter, and thunderstorms occur during the late summer. February has the most precipitation, and June has the least precipitation (ARL/SORD, 2011). Annual ET ref at the Area 5 RWMS, calculated using local meteorology data, is approximately 13 times the annual average precipitation (Desotell et al., 2006).

Areas 3 and 5 are similar, except for slight differences in air temperature, precipitation, and soil texture. Area 3 receives approximately 30\% more rainfall than Area 5, and the annual average temperature at Area 3 is about $2^{\circ} \mathrm{C}\left(4^{\circ} \mathrm{F}\right)$ cooler than at Area 5 .

\subsection{HYDROLOGIC CONCEPTUAL MODEL OF THE AREA 3 AND AREA 5 RWMS}

Climate and vegetation strongly control the water movement in the upper few meters of alluvium at both RWMSs. The magnitude and direction of both liquid and vapor fluxes vary seasonally and often daily. Except for periods following precipitation events, water content values in the near-surface are quite low. Below the dynamic near-surface is a region where relatively steady upward water movement is occurring. In this region of slow upward flow, stable isotope compositions of soil water confirm that evaporation $(E)$ is the dominant process (Tyler et al., 1996). The upward flow region extends to depths from approximately 3 to $49 \mathrm{~m} \mathrm{(10} \mathrm{to} 160 \mathrm{ft}$ ) in Area 3, and from approximately 3 to $40 \mathrm{~m} \mathrm{(10} \mathrm{to} 131 \mathrm{ft}$ ) in Area 5. Below the upward flow region, 
water potential measurements indicate the existence of a static region. The hydraulic gradient in the static region is zero. The static region is between approximately 49 and $119 \mathrm{~m}$ (160 to $390 \mathrm{ft}$ ) deep in Area 3, and between approximately 40 and $90 \mathrm{~m}$ (131 to $295 \mathrm{ft}$ ) deep in Area 5 (Shott et al., 1997; 1998). In the static region, essentially no vertical liquid flow is currently occurring. Below the static region, flow is steady and downward due to gravity (Figure 2-2). Stable isotope compositions of soil water from these depths indicate that infiltration into this zone occurred under cooler past climatic conditions (Tyler et al., 1996). If water were to migrate below the current static zones, movement to the groundwater would be extremely slow due to the low water content of the alluvium. Estimates of travel time to the groundwater (assuming zero upward flux), based on hydraulic characteristics of the alluvium, and assuming that current conditions would still apply, are in excess of 500,000 years in Area 3 (Levitt and Yucel, 2002) and 50,000 years in Area 5 (Shott et al., 1998).

Based on the results of extensive research, field studies, modeling efforts, and monitoring data, which are summarized in the Area 3 and Area 5 PAs (Shott et al., 1997; 1998; Levitt et al., 1999; Levitt and Yucel, 2002; Desotell et al., 2006), groundwater recharge is not occurring under current climatic conditions at the RWMSs. Studies indicate that under bare-soil conditions, such as those found at the operational waste cell covers, some drainage may eventually occur through the waste covers into the waste zone. This drainage is estimated to be about $8 \%$ of the annual rainfall at Area 5 , based on one-dimensional modeling results (Desotell et al., 2006).

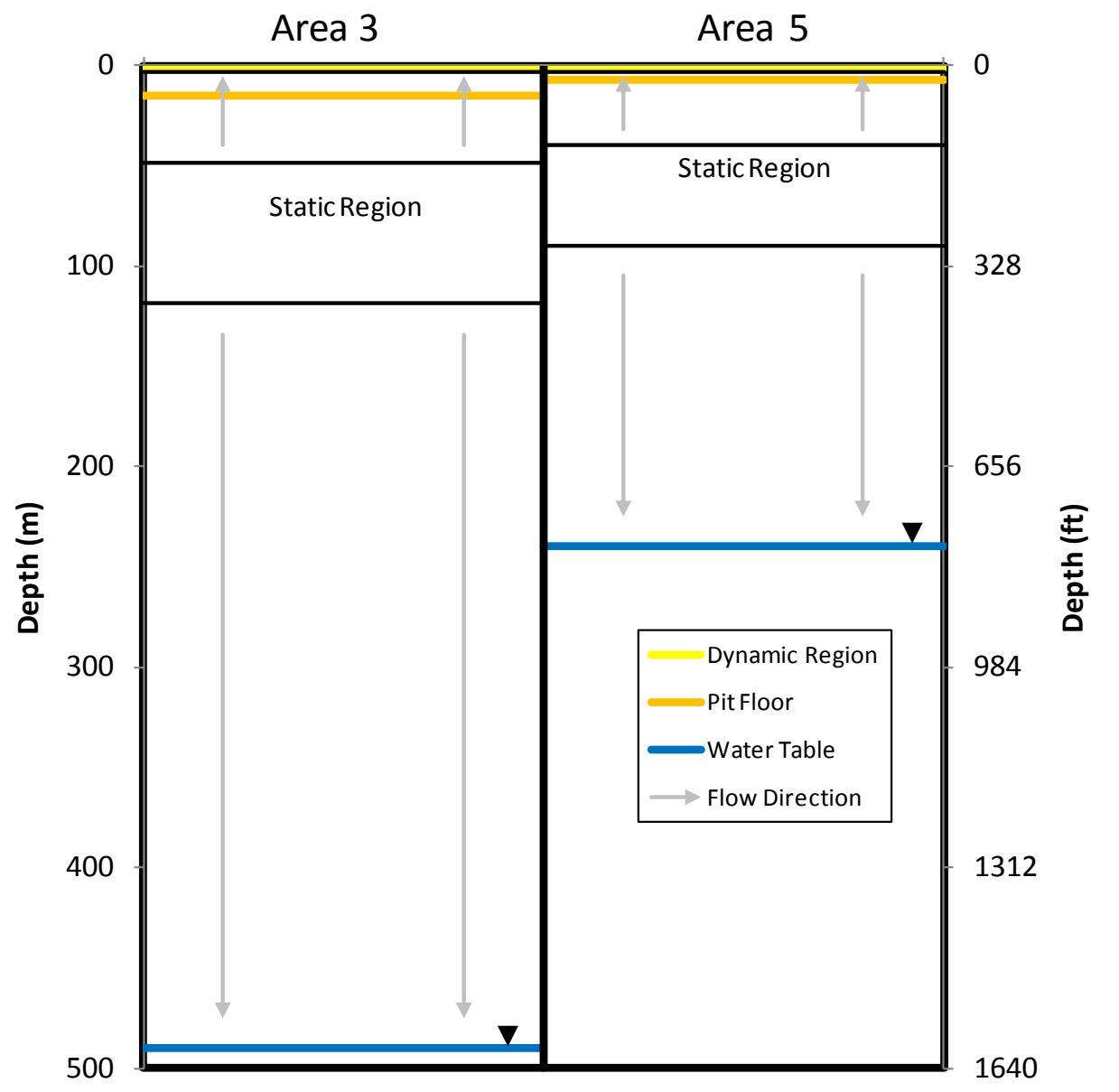

Figure 2-2. Vadose Zone Conceptual Models of the Area 3 and Area 5 RWMSs 


\subsection{PROJECT DESCRIPTION}

The Area 3 and Area 5 RWMSs are designed and operated for the disposal of radioactive low-level waste (LLW) and mixed waste that is generated at the NNSS, from DOE offsite locations, and from other approved offsite generators.

\subsection{AREA 3 RWMS}

Waste disposal cells within the Area 3 RWMS are subsidence craters resulting from underground nuclear testing. At the time of formation, the seven craters within the Area 3 RWMS ranged from 122 to $177 \mathrm{~m}$ (400 to $580 \mathrm{ft}$ ) in diameter and from 14 to $32 \mathrm{~m}$ (46 to $105 \mathrm{ft}$ ) in depth (Plannerer, 1996). Five of these craters have been used for waste disposal. Disposal in the U-3ax crater began in the late 1960s, and disposal in U-3bl began in 1984. Waste forms consisted primarily of contaminated soil and scrap metal, with some construction debris, equipment, and containerized waste. Craters $U-3 a x$ and $U-3 b l$ were combined to form the U-3ax/bl disposal unit (Corrective Action Unit [CAU] 110), which is now covered with a

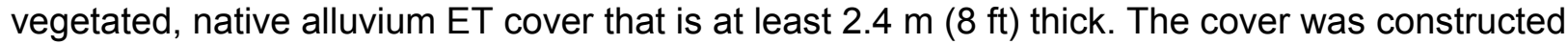
in 2000. For details of the final closure plan of CAU 110, refer to BN (2001). Disposal in the combined unit U-3ah/at began in 1988. Disposal cell U-3ah/at has been used for disposal of bulk LLW from the NNSS and approved offsite generators. Crater U-3bh was originally used for disposal of contaminated soils from the Tonopah Test Range in 1997 and has been used since for waste disposal from other approved generators. The remaining two craters are not in use (Figure 3-1). For a detailed description of the facilities at the Area 3 RWMS, refer to Shott et al. (1997) and NSTec (2007). No waste has been disposed at the Area 3 RWMS since 2006. 


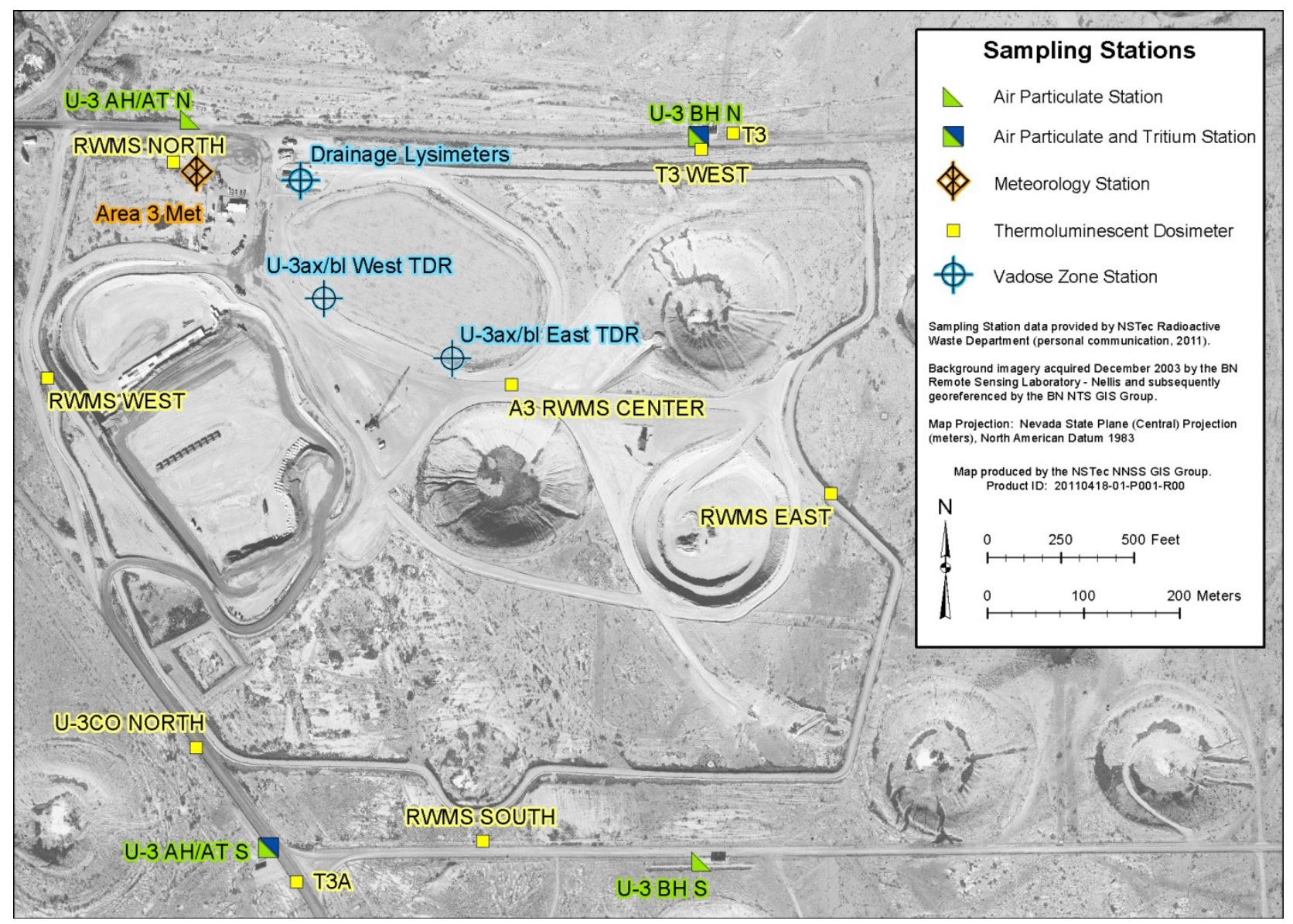

Figure 3-1. Monitoring Locations at the Area 3 RWMS

\subsection{AREA 5 RWMS}

Waste disposal has occurred at the Area 5 RWMS since the early 1960s. The Area 5 RWMS consists of 38 landfill cells (pits and trenches) and 13 GCD boreholes (Figure 3-2). Some previous documents list fewer landfill cells, but new cells continue to be constructed, and Trench 4 was separated into T04A and T04A1 (BN, 2005c). Pits and trenches range in depth from 4.6 to $15 \mathrm{~m}$ (15 to $48 \mathrm{ft}$ ). The unlined disposal units receive sealed waste containers. Containers are stacked to approximately $1.2 \mathrm{~m}(4 \mathrm{ft})$ below original grade, and soil backfill is pushed over the

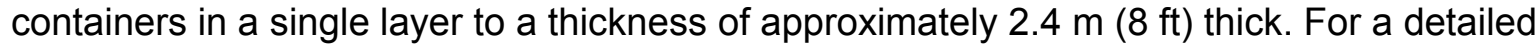
description of the facilities at the Area 5 RWMS, refer to Shott et al. (1998). For further descriptions of pits, trenches, and GCD boreholes, refer to BN (2005c; 2006) and Cochran et al. (2001).

Waste was disposed in nine pits and one trench at the Area 5 RWMS during 2011. The cells that received waste are P06, P10, P12, P13, P16, P17, P18, P19, P20, and T13. P18 began receiving mixed waste during 2011, and $\mathrm{P} 18$, $\mathrm{P} 19$, and $\mathrm{P} 20$ began receiving LLW. All active pits contain LLW, and P18 contains mixed LLW. P06 received its last waste in 2011.

Preliminary closure work for the approximately 92-Acre Area in the southern portion of the Area 5 RWMS began in 2010 and was completed in January 2012 (see Figure 3-2). During 2010, fencing, signs, monuments, and utilities were removed; casing was removed from 
approximately 50 shallow boreholes, and these boreholes were filled with cement; GCD-06, GCD-07, GCD-08, GCD-09, GCD-11, and GCD-12 were backfilled to the surface with native soil, and the sampling apparatus for GCD-05 was removed; and preliminary grading for final closure started. An engineered ET cover with a minimum $2.5 \mathrm{~m}(8.2 \mathrm{ft})$ thickness over waste was constructed from January to May 2011. The engineered ET cover within the 92-Acre Area is approximately 18.2 hectares ( 45 acres). The cover is designed with drainage features and slopes to minimize erosion. The soil bulk density of the final ET cover is between 1.39 and 1.57 grams per cubic centimeter ( 86.8 to 99.3 pounds per cubic foot). This bulk density is between $75 \%$ and $85 \%$ of the maximum dry bulk density from modified Proctor tests and provides an adequate seedbed for vegetation. After grading and soil preparation were complete, a soil stabilizer was applied to the surface for temporary erosion and sediment control until seeding could be done in the fall. The ET cover was vegetated from October to December 2011. The surface was disked and seeded with a mixture of native plant species. After seeding, straw mulch was spread and crimped into the surface. A solid-set irrigation system was installed for irrigation during seed germination in the following spring. ET cover construction was completed by installing 52 subsidence survey monuments and use restriction signs during January 2012 (Goodrich, 2010; NNSA/NSO 2010; 2012; Delphi and Cesare, 2012).

The 92-Acre Area ET cover closed 9 pits (P01, P02, P03, P04, P05, P06, P07, P09, and P11), 16 trenches (T01B, T02B, T03B, T04B, T06B, T07B, T01A, T02A, T03A, T04A, T04A-1, T05, T06A, T07A, T08, and T09), 13 GCD boreholes (GCD-DT, GCD-01, GCD-02, GCD-03, CGD-04, GCD-05, GCD-06, GCD-07, GCD-08, GCD-09, GCD-10, GCD-11, and GCD-12), and the CWI Trenches. P26 was also closed by the ET cover, but it is completely within P03. P08 and $\mathrm{P} 15$ are operationally closed. 


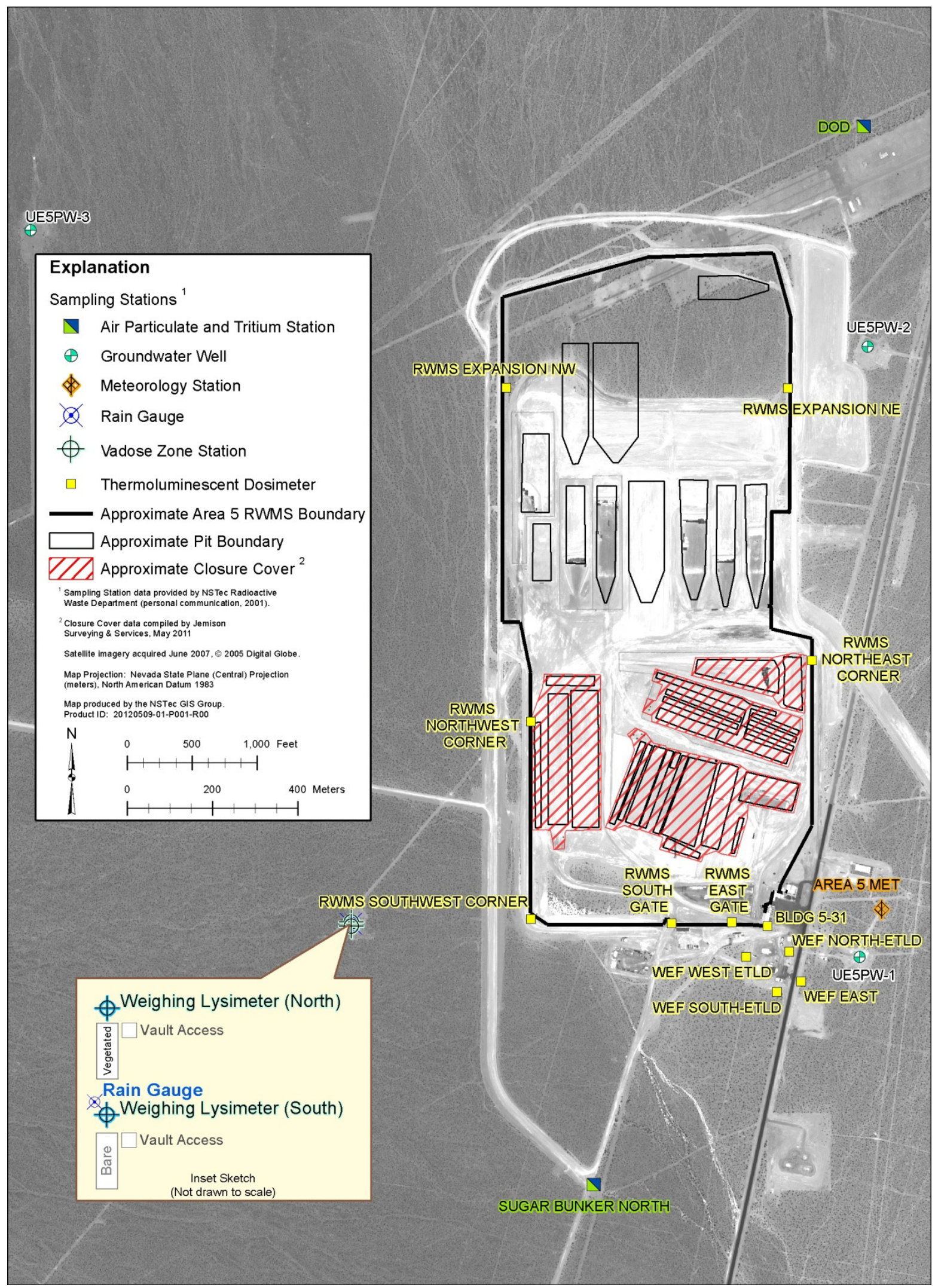

Figure 3-2. Monitoring Locations at the Area 5 RWMS 


\subsection{ENVIRONMENTAL MONITORING DATA}

\subsection{TYPES OF ENVIRONMENTAL MONITORING DATA}

Area 3 RWMS monitoring locations are shown in Figure 3-1, and Area 5 RWMS monitoring locations are shown in Figure 3-2. This report provides a general description and graphical representations of some of these data. Monitoring data being collected include:

- Radiation Exposure Data

- Quarterly thermoluminescent dosimeter (TLD) measurements

- Air Monitoring Data

- Weekly Data

- Alpha concentrations

- Beta concentrations

- Biweekly Data

- Tritium concentrations

- Monthly Data

- Gamma concentrations

- Americium (Am) concentrations

- Plutonium (Pu) concentrations

- Periodic radon flux measurements from waste covers

- Groundwater Monitoring Data

- Quarterly Water-Level Measurements

- Semiannual Indicators of Contamination

- $\mathrm{pH}$ (field measurement)

- Specific conductance (SC) (field measurement)

- Total organic carbon (TOC)

- Total organic halides (TOX)

- Tritium

- Semiannual General Water Chemistry Parameters

- Total calcium, iron, magnesium, manganese, potassium, sodium, silicon

- Total sulfate, chloride, fluoride

- Alkalinity

- Biennial RREMP Analyses

- Gross alpha

- Gross beta

- Gamma spectroscopy

- Plutonium $\left({ }^{238} \mathrm{Pu}\right.$ and $\left.{ }^{239+240} \mathrm{Pu}\right)$

- Triennial RREMP Analyses for Specific Radionuclides

- Strontium-90 $\left({ }^{90} \mathrm{Sr}\right)$

- Technetium-99 $\left({ }^{99} \mathrm{Tc}\right)$

- Carbon-14 $\left({ }^{14} \mathrm{C}\right)$ 
- Meteorology Monitoring Data

- Daily Meteorology Data

- Average air temperature at $3.0 \mathrm{~m}(9.8 \mathrm{ft})$ and $9.5 \mathrm{~m}(31.1 \mathrm{ft})$ above ground level (AGL)

- Maximum air temperature at $3.0 \mathrm{~m}(9.8 \mathrm{ft})$ and $9.5 \mathrm{~m}(31.1 \mathrm{ft}) \mathrm{AGL}$

- Minimum air temperature at $3.0 \mathrm{~m}(9.8 \mathrm{ft})$ and $9.5 \mathrm{~m}(31.1 \mathrm{ft}) \mathrm{AGL}$

- Average relative humidity at $3.0 \mathrm{~m}(9.8 \mathrm{ft})$ and $9.5 \mathrm{~m}(31.1 \mathrm{ft}) \mathrm{AGL}$

- Maximum relative humidity at $3.0 \mathrm{~m}(9.8 \mathrm{ft})$ and $9.5 \mathrm{~m}(31.1 \mathrm{ft}) \mathrm{AGL}$

- Minimum relative humidity at $3.0 \mathrm{~m}(9.8 \mathrm{ft})$ and $9.5 \mathrm{~m}(31.1 \mathrm{ft}) \mathrm{AGL}$

- Average wind speed at $3.0 \mathrm{~m}(9.8 \mathrm{ft})$ and $9.5 \mathrm{~m}(31.1 \mathrm{ft}) \mathrm{AGL}$

- Maximum wind speed at $3.0 \mathrm{~m}(9.8 \mathrm{ft})$ and $9.5 \mathrm{~m}(31.1 \mathrm{ft}) \mathrm{AGL}$

- Average barometric pressure

- Maximum barometric pressure

- Minimum barometric pressure

- Total precipitation

- Hourly Meteorology Data

- Average air temperature at $3.0 \mathrm{~m}(9.8 \mathrm{ft})$ and $9.5 \mathrm{~m}(31.1 \mathrm{ft}) \mathrm{AGL}$

- Average relative humidity at $3.0 \mathrm{~m}(9.8 \mathrm{ft})$ and $9.5 \mathrm{~m}(31.1 \mathrm{ft}) \mathrm{AGL}$

- Average wind speed at $3.0 \mathrm{~m}(9.8 \mathrm{ft})$ and $9.5 \mathrm{~m}(31.1 \mathrm{ft}) \mathrm{AGL}$

- Average wind direction $3.0 \mathrm{~m}(9.8 \mathrm{ft})$ and $9.5 \mathrm{~m}(31.1 \mathrm{ft}) \mathrm{AGL}$

- Average barometric pressure

- Average solar radiation

- Total precipitation

- Vadose Zone Monitoring Data

- Annual Soil Gas Monitoring Data (soil gas tritium concentrations measured at GCD-05 gas sampling ports [nine depths])

- Weighing Lysimeter Data (Area 5)

- Daily and hourly $E$ from the bare-soil weighing lysimeter

- Daily and hourly ET from the vegetated weighing lysimeter

- Daily and hourly precipitation and 5-minute precipitation rates

- Daily soil volumetric water content (VWC) and soil water potential

- Hourly soil temperature with depth

- Drainage Lysimeter Data (Area 3)

- Daily Soil VWC, soil water potential, and water storage with depth

- Hourly temperature with depth

- Daily and hourly drainage from each lysimeter

- Daily Automated Vadose Zone Monitoring System Data

- Soil VWC with depth in waste covers

- Soil VWC beneath waste cells

- Soil water potential with depth in waste covers

- Soil temperature with depth in waste covers 
- Periodic Subsidence Monitoring Data: Locations and descriptions of subsidence features on waste covers

- Biota Monitoring Data: Periodic analysis of plant and animal samples for tritium and other radionuclide concentrations

\subsection{RADIATION EXPOSURE DATA}

Direct radiation monitoring assesses and detects changes in the external radiation environment and measures gamma radiation levels near potential exposure sites. Performance objectives in DOE O 435.1 require that LLW disposal facilities be sited, designed, operated, maintained, and closed, so it is reasonable to expect less than 25 millirem per year (mrem/yr) total effective dose equivalent to representative members of the public from the facility. The effective dose equivalent is from all exposure pathways associated with the facility, but does not include the dose from radon or background. The RWMSs are located well within the NNSS boundaries, so the public does not have access to these areas for significant periods of time. However, exposure rates measured by TLDs located at the RWMSs show the potential dose to a hypothetical person residing continuously at the RWMS.

TLDs (Panasonic UD 814AS) are used to measure ionizing radiation exposure from all sources, including natural and man-made radioactivity. These TLDs have three calcium sulfate elements housed in an air-tight, water-tight, ultraviolet-light-protected case. The elements measure the total exposure rate from penetrating gamma radiation including background. The penetrating gamma radiation makes up the deep dose, which is compared to the $25 \mathrm{mrem} / \mathrm{yr}$ limit when background exposure is subtracted.

Figure 3-1 and Figure 3-2 show TLD monitoring locations near the Area 3 and Area 5 RWMSs. A pair of TLDs is placed $1 \pm 0.3 \mathrm{~m}$ (28 to $51 \mathrm{in}$.) AGL at each location and are exchanged for analysis on a quarterly basis. TLDs are analyzed using automated TLD readers that are calibrated and maintained by the NSTec Radiological Control Department. Reference TLDs exposed to 100 milliroentgen $(\mathrm{mR})$ from a cesium-137 $\left({ }^{137} \mathrm{Cs}\right)$ radiation source under controlled conditions are used to scale the response of the measurement TLDs. Direct radiation exposure is usually reported in the unit $\mathrm{mR}$, which is a measure of exposure in terms of numbers of ionizations in air. Generally, the dose in human tissue resulting from an exposure from the most common external radionuclides can be approximated by equating a $1 \mathrm{mR}$ exposure with a 1 millirem (mrem) dose.

Between 1952 and 1972, 60 nuclear weapons tests were conducted within $400 \mathrm{~m}(1,312 \mathrm{ft})$ of the Area 3 RWMS boundary. Fourteen of these tests were atmospheric tests, which left radionuclide-contaminated surface soil with elevated radiation exposures across the area. Waste pits in the Area 3 RWMS are subsidence craters from seven subsurface tests that are being filled with LLW. During disposal operations, the waste is covered with clean soil, resulting in lower exposures inside the Area 3 RWMS when compared with the average exposures at the Area 3 RWMS fence line or in Area 3 outside the fence line.

Annual radiation exposures in milliroentgen per year (mR/yr) during 2011 at locations inside and near the Area 3 RWMS range from 130 to $360 \mathrm{mR} / \mathrm{yr}$ (Figure 4-1). The Area 3 monitoring locations are (1) inside the Area 3 RWMS (RWMS Center), (2) on the RWMS boundary (RWMS North, RWMS East, RWMS South, RWMS West), and (3) outside the RWMS boundary (T3, T3 West, T3A, and U3CO North) (Figure 3-1). The exposures measured inside the Area 3 RWMS and three of four measurements at the boundary are within the range of background exposures. 
The four TLD locations outside the Area 3 RWMS boundary and RWMS South (boundary location) have higher exposures due to nearby historical aboveground nuclear weapons tests. This distribution of exposures indicates radionuclides in the Area 3 RWMS would contribute negligible external exposure to a hypothetical person residing at the Area 3 RWMS when compared to the exposures from historical aboveground nuclear weapons tests. Estimated daily exposure rates in milliroentgen per day ( $\mathrm{mR} /$ day) from the quarterly exposure rate data at the Area 3 RWMS are within the range of exposure rates at NNSS background locations (Figure 4-2).

Between 1951 and 1971, 25 nuclear weapons tests were conducted within $6.3 \mathrm{~km}$ (3.9 mi) of the Area 5 RWMS. Fifteen of these were atmospheric tests, and nine of the remaining ten tests released radioactivity to the surface. There were no nuclear weapons tests within the boundaries of the Area 5 RWMS. There were 12 TLD monitoring locations in and around the Area 5 RWMS; however, during construction of the 92-Acre Area ET cover, the data from the Area 5 RWMS NW Corner was compromised and discarded. Estimated daily exposure rates from the quarterly exposure data at the Area 5 RWMS are within the range of exposures measured at NNSS background locations (Figure 4-3).

Comparisons of 2002 to 2011 direct radiation exposure data using TLDs from the two RWMSs with direct radiation data from NNSS background locations indicate that direct radiation exposure at the Area 3 and Area 5 RWMSs is generally low or declining (Figure 4-2 and Figure 4-3).

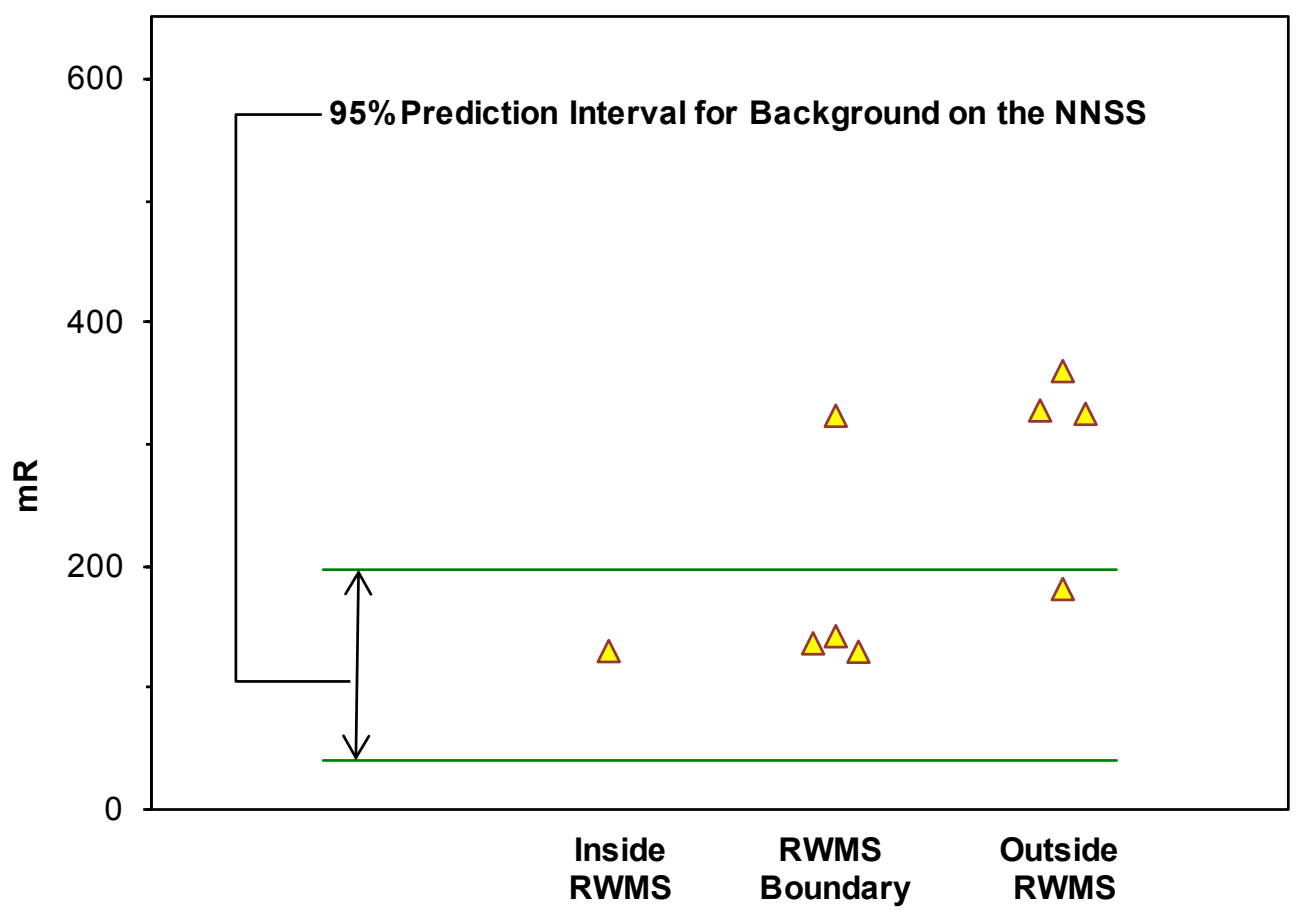

Figure 4-1. Annual Radiation Exposure Rates at the Area 3 RWMS during 2011 


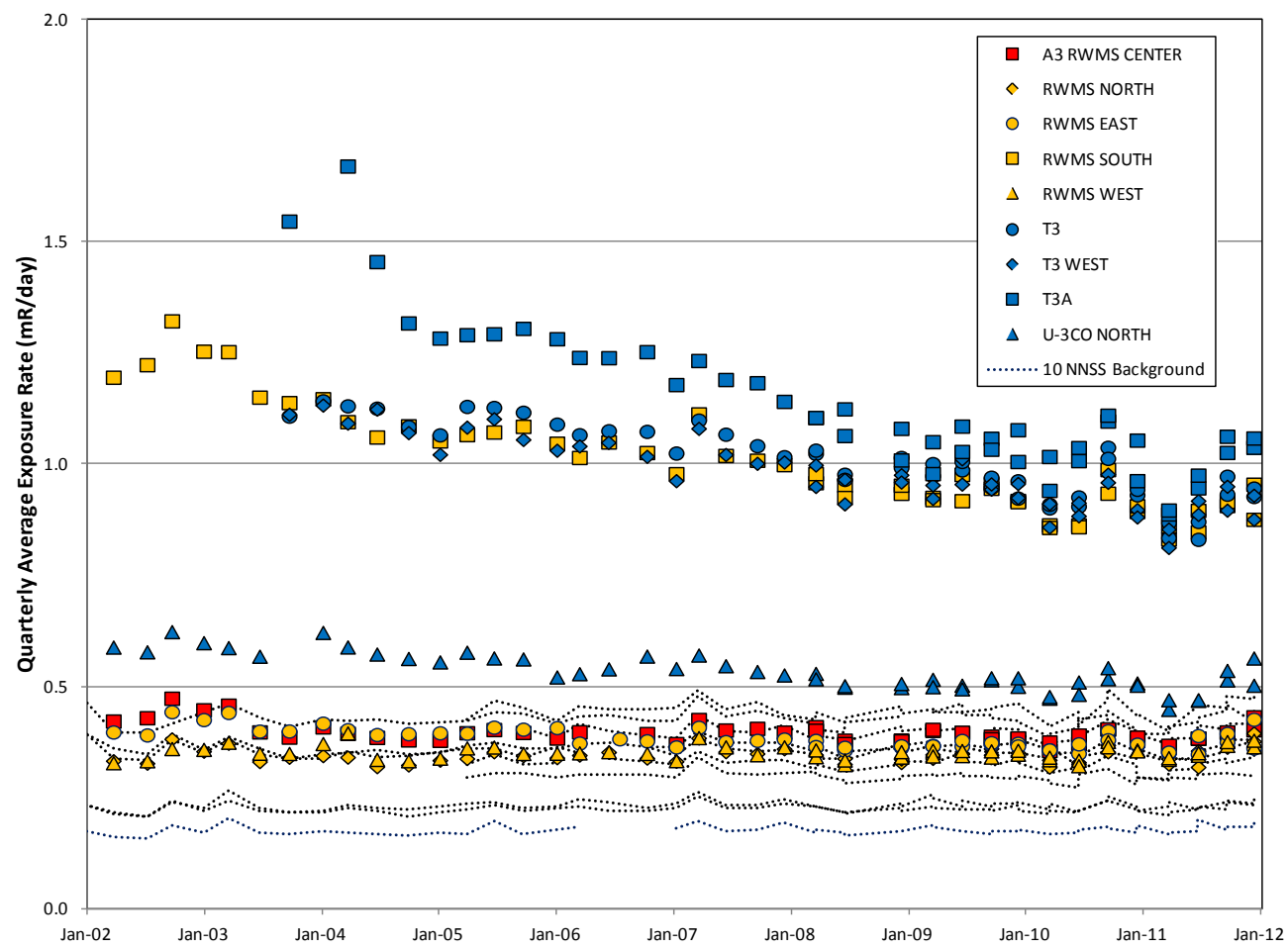

Figure 4-2. Quarterly Average Daily Exposure Rates at the Area 3 RWMS and NNSS Background TLD Locations from 2002 through 2011

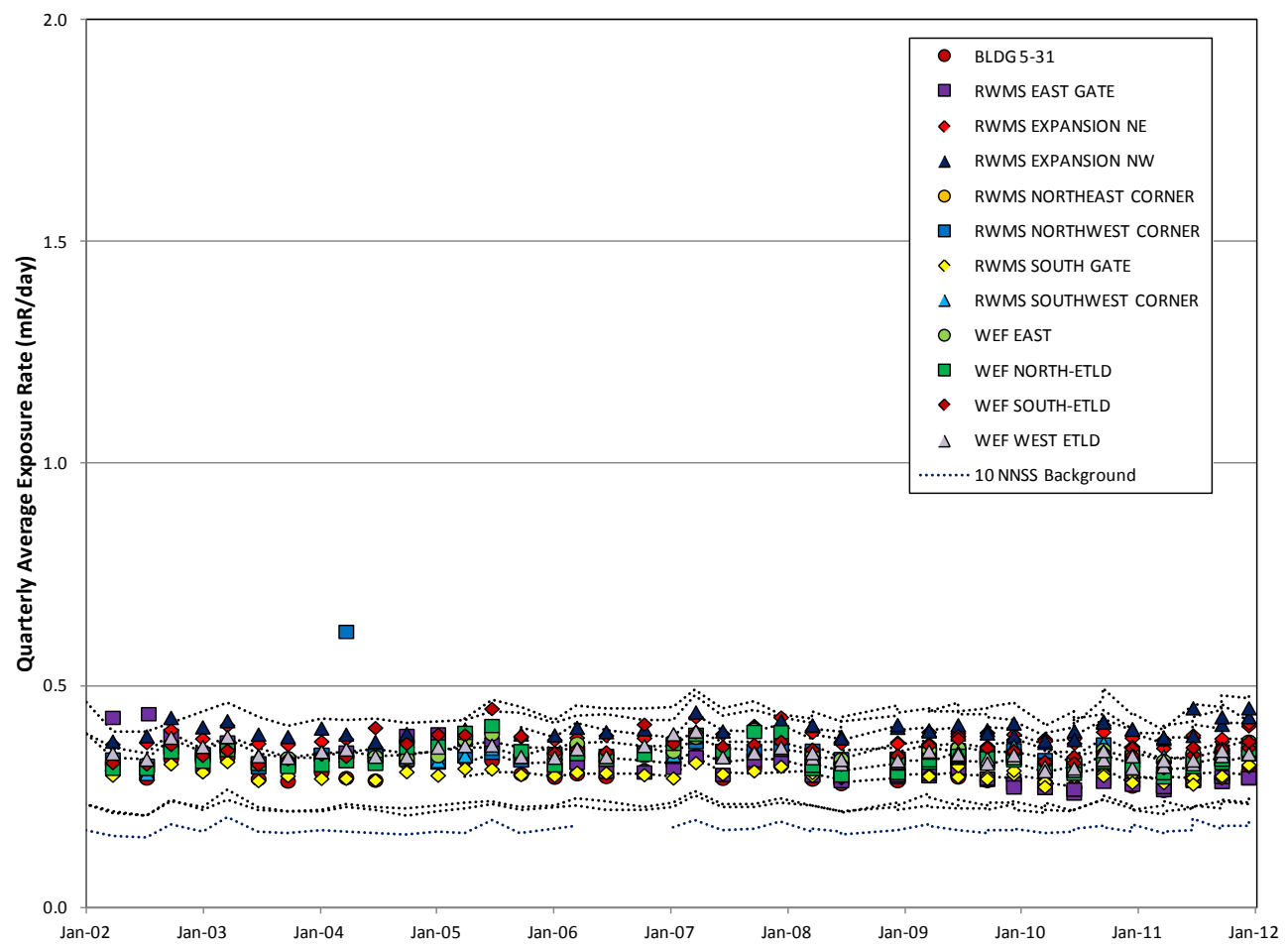

Figure 4-3. Quarterly Average Daily Exposure Rates at the Area 5 RWMS and NNSS Background TLD Locations from 2002 through 2011 


\subsection{AIR MONITORING DATA}

\subsubsection{Tritium}

Tritium is a highly mobile isotope of hydrogen that acts as a conservative tracer. It is an excellent performance indicator of volatile radionuclide migration from waste cells. Atmospheric moisture is continuously collected at the Area 3 and Area 5 RWMSs and analyzed for tritium. Approximately 11 cubic meters $\left(\mathrm{m}^{3}\right)$ (388 cubic feet $\left[\mathrm{ft}^{3}\right]$ ) of air are drawn across a desiccant during each 2-week sample period to collect atmospheric moisture. Moisture is distilled from the desiccant, and tritium activity is measured by liquid scintillation.

The two tritium monitoring locations at the Area 3 RWMS are U-3bh N and U-3ah/at $S$ (Figure 3-1). The two Area 5 RWMS monitoring locations are DoD and Sugar Bunker. DoD is approximately $1.0 \mathrm{~km}(0.6 \mathrm{mi})$ north of the Area $5 \mathrm{RWMS}$, and Sugar Bunker is approximately $1.5 \mathrm{~km}(0.9 \mathrm{mi})$ south of the Area 5 RWMS (Figure 3-1 and Figure 3-2). These monitoring locations are in the prevailing downwind directions to provide adequate environmental monitoring for each RWMS.

During 2011, tritium concentrations at the Area 3 and Area 5 RWMSs ranged from -0.84 to 2.48 picocuries per cubic meter $\left(\mathrm{pCi} / \mathrm{m}^{3}\right)$. All results are well below the $\mathrm{DOE}$ derived concentration guide (DCG) (DOE O 5400.5) for tritium adjusted to the $25 \mathrm{mrem} / \mathrm{yr}$ exposure specified in DOE O 435.1. In general, higher tritium concentrations occur in September through October (Figure 4-4).

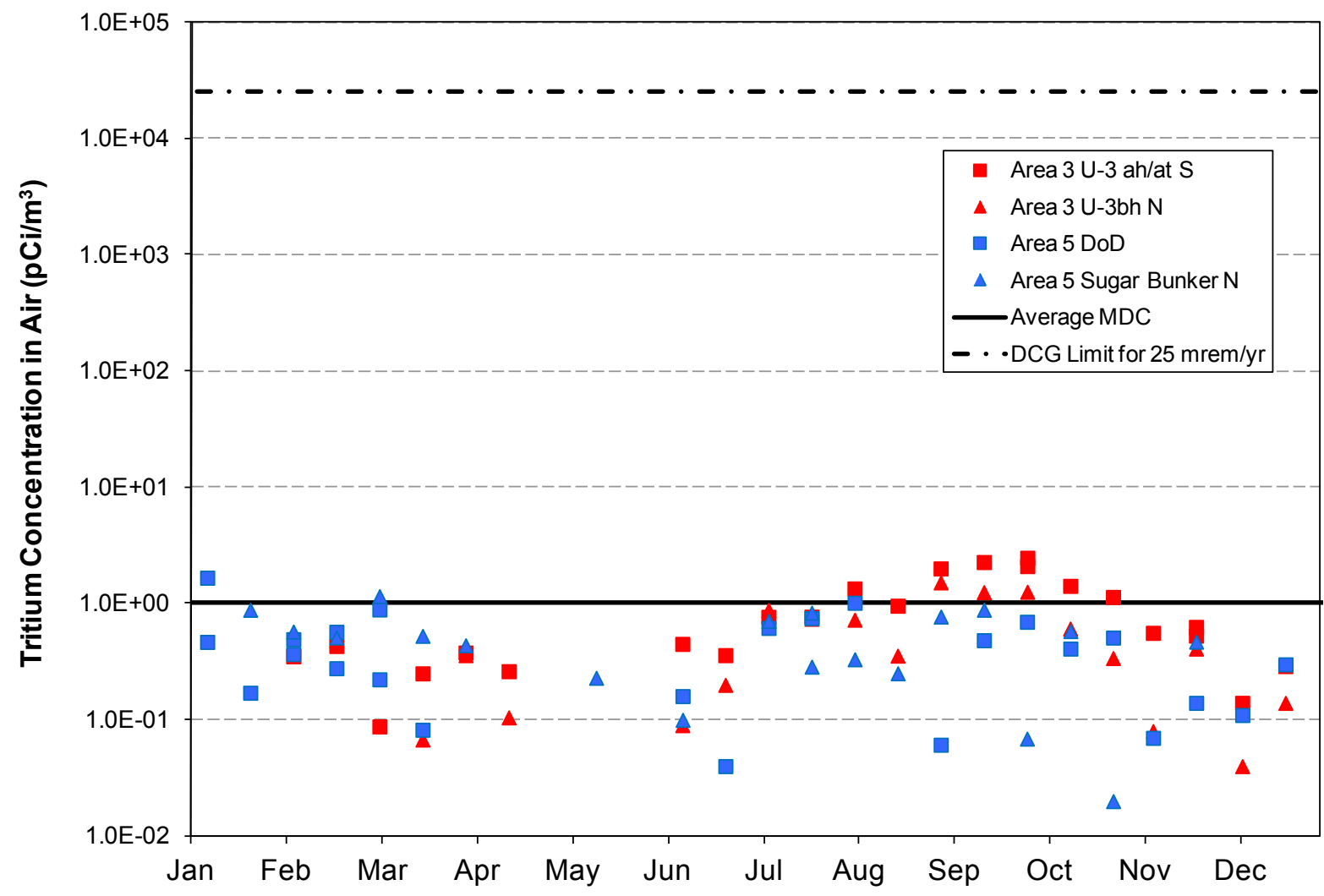

Figure 4-4. Tritium Concentration in Air at the Area 3 and Area 5 RWMSs during 2011 


\subsubsection{Particulates}

Air particulate samples are collected weekly on glass-fiber filters near each RWMS and are screened for gross alpha and gross beta radioactivity. This provides early detection of any change in environmental concentrations of airborne radioactivity. Monthly composites of the filters from each sampling location are analyzed by gamma spectroscopy for gamma-emitting radioactivity and by radiochemical analyses for americium and plutonium.

The four air particulate monitoring locations at the Area 3 RWMS are U-3bh N, U-3bh S, U-3ah/at N, and U-3ah/at S (Figure 3-1). The two air particulate monitoring locations at the Area 5 RWMS are DoD and Sugar Bunker (Figure 3-2).

The alpha spectroscopy results for ${ }^{241} \mathrm{Am},{ }^{238} \mathrm{Pu}$, and ${ }^{239+240} \mathrm{Pu}$ from 2011 for each location are above the minimum detectable concentrations (MDCs) in $33 \%$ to $83 \%$ of the samples for ${ }^{241} \mathrm{Am}$ (Figure 4-5), above the MDCs in $8 \%$ to $50 \%$ of samples for ${ }^{238} \mathrm{Pu}$ (Figure 4-6), and above the MDCs in $25 \%$ to $92 \%$ of samples for ${ }^{239+240} \mathrm{Pu}$ (Figure $4-7$ ). The americium and plutonium concentrations at the Area 3 RWMS are slightly higher than the concentrations at the Area 5 RWMS. There is no indication that RWMS operations contributed americium or plutonium activity above normal variability observed at all locations. All measured concentrations of americium and plutonium were below the DCG, adjusted to $25 \mathrm{mrem} / \mathrm{yr}$ for each radionuclide.

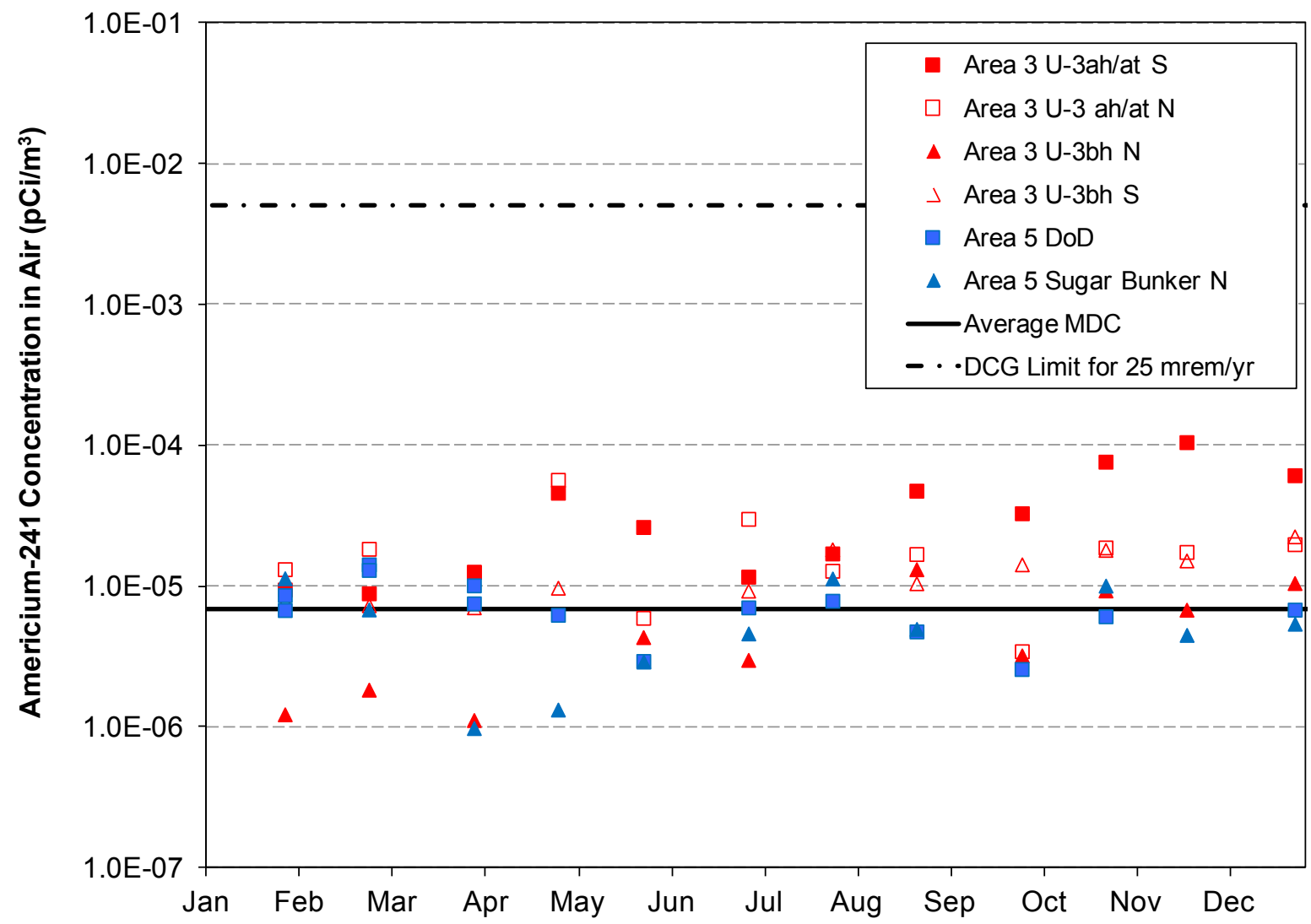

Figure 4-5. Concentration of ${ }^{241} \mathrm{Am}$ in Air at the Area 3 and Area 5 RWMSs during 2011 


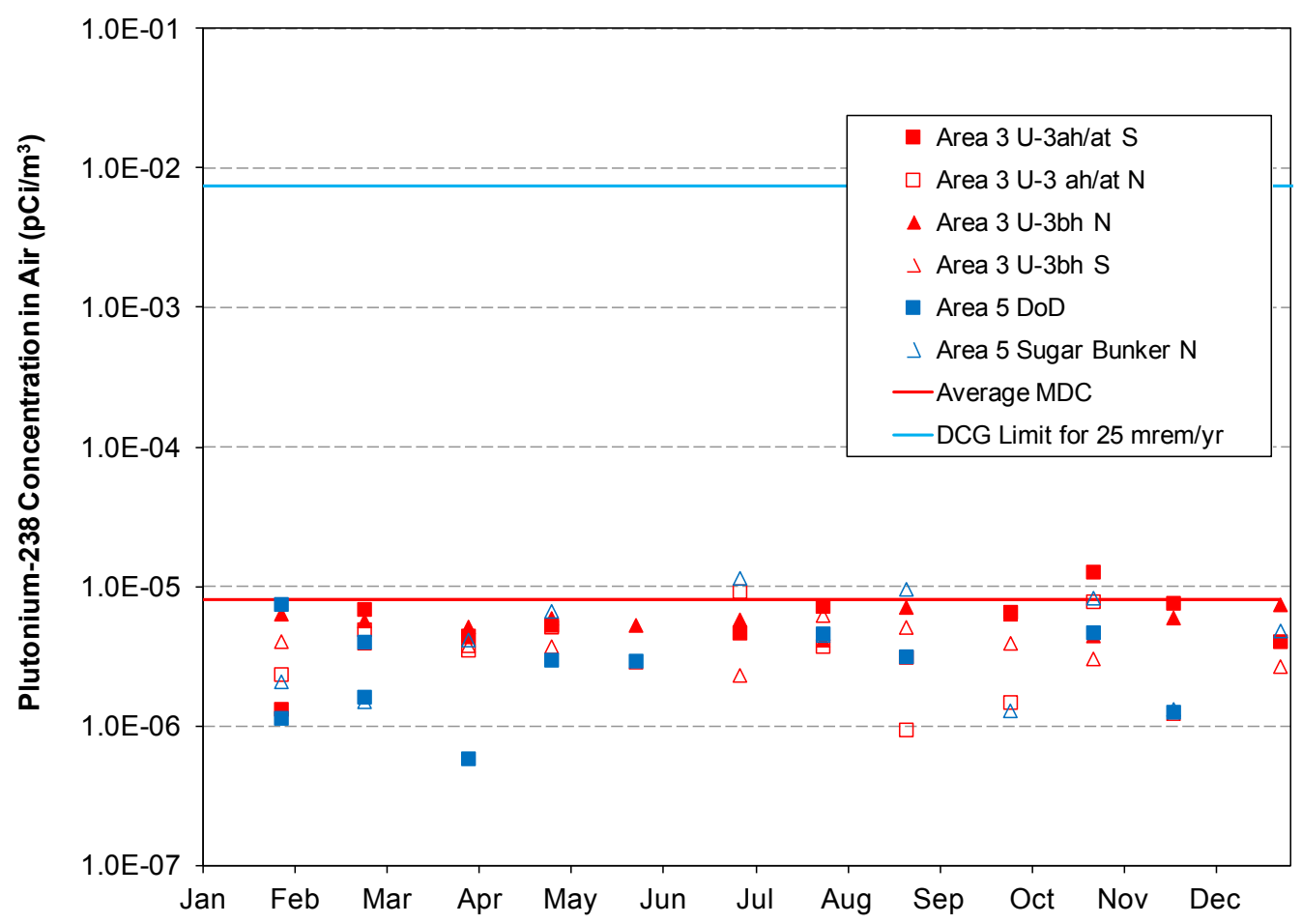

Figure 4-6. Concentration of ${ }^{238} \mathrm{Pu}$ in Air at the Area 5 and Area 3 RWMSs during 2011

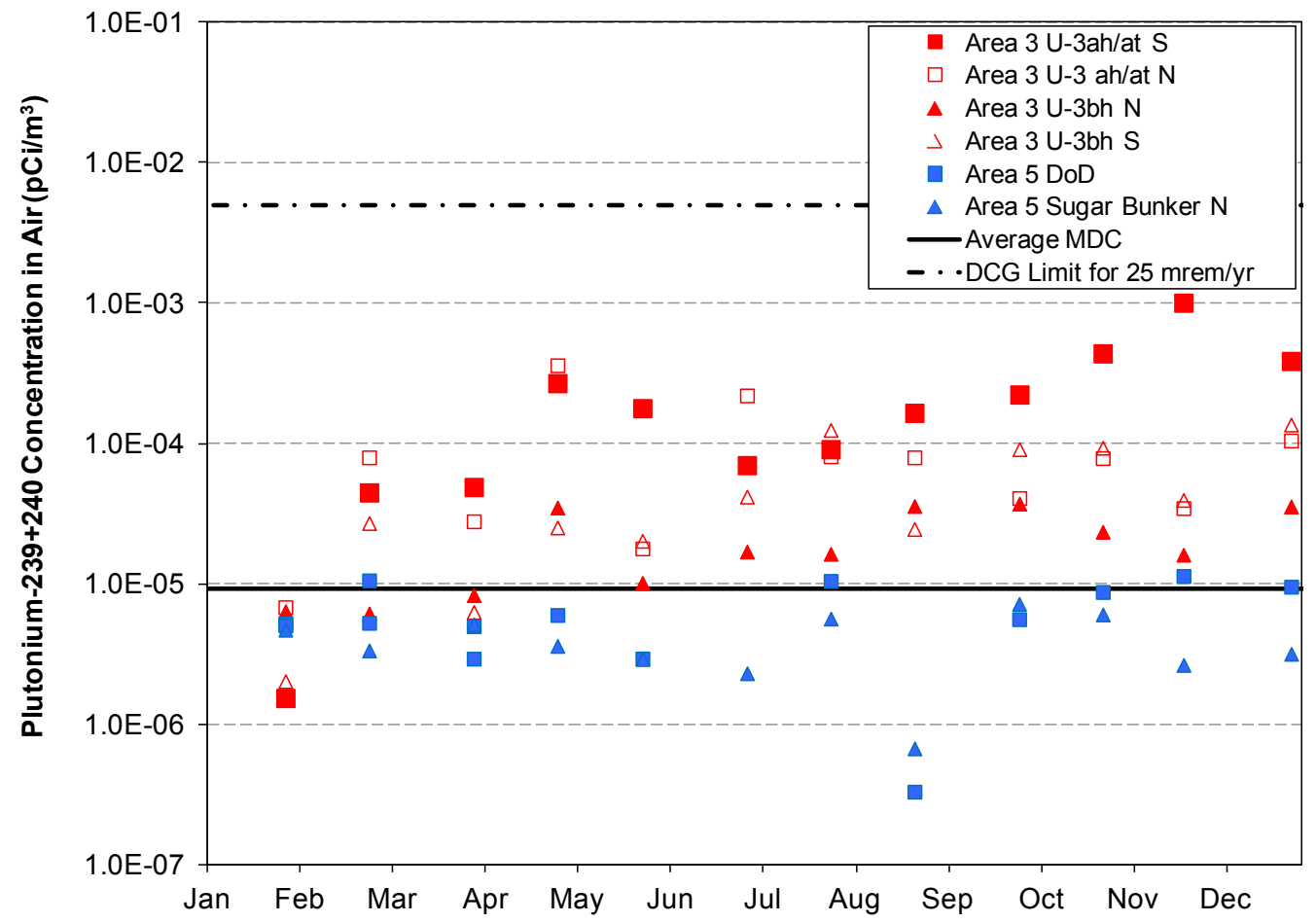

Figure 4-7. Concentration of ${ }^{239+240} \mathrm{Pu}$ in Air at the Area 5 and Area 3 RWMSs during 2011 
During the last 2 weeks of March 2011, gamma spectroscopy results showed measurable activities of the man-made radionuclides iodine-131 $\left({ }^{131} \mathrm{I}\right)$, cesium-134 $\left({ }^{134} \mathrm{Cs}\right)$, and cesium-137 $\left({ }^{137} \mathrm{Cs}\right)$. These results are attributed to the large release of fission products from the Fukushima Daiichi nuclear power plant in Japan that was damaged by a March 11, 2011, earthquake and resulting tsunami (Institute of Nuclear Power Operations, 2011) and are not related to operations at the NNSS. Radionuclides from this release were detected in air samples throughout the northern hemisphere (Bolsunovsky and Dementyev, 2011; Carvalho et al., in press; Thakur et al., 2012), including southern Nevada. These Japan-based radionuclides $\left({ }^{131}\right.$ I, ${ }^{134} \mathrm{Cs}$, and ${ }^{137} \mathrm{Cs}$ ) were observed consistently throughout the western United States during the last 2 weeks of March (Leon et al., 2011; EPA, 2011; Community Environmental Monitoring Program, 2011). Figure 4-8 provides the ${ }^{137} \mathrm{Cs}$ activity for the monitoring locations at the Area 3 and Area 5 RWMSs.

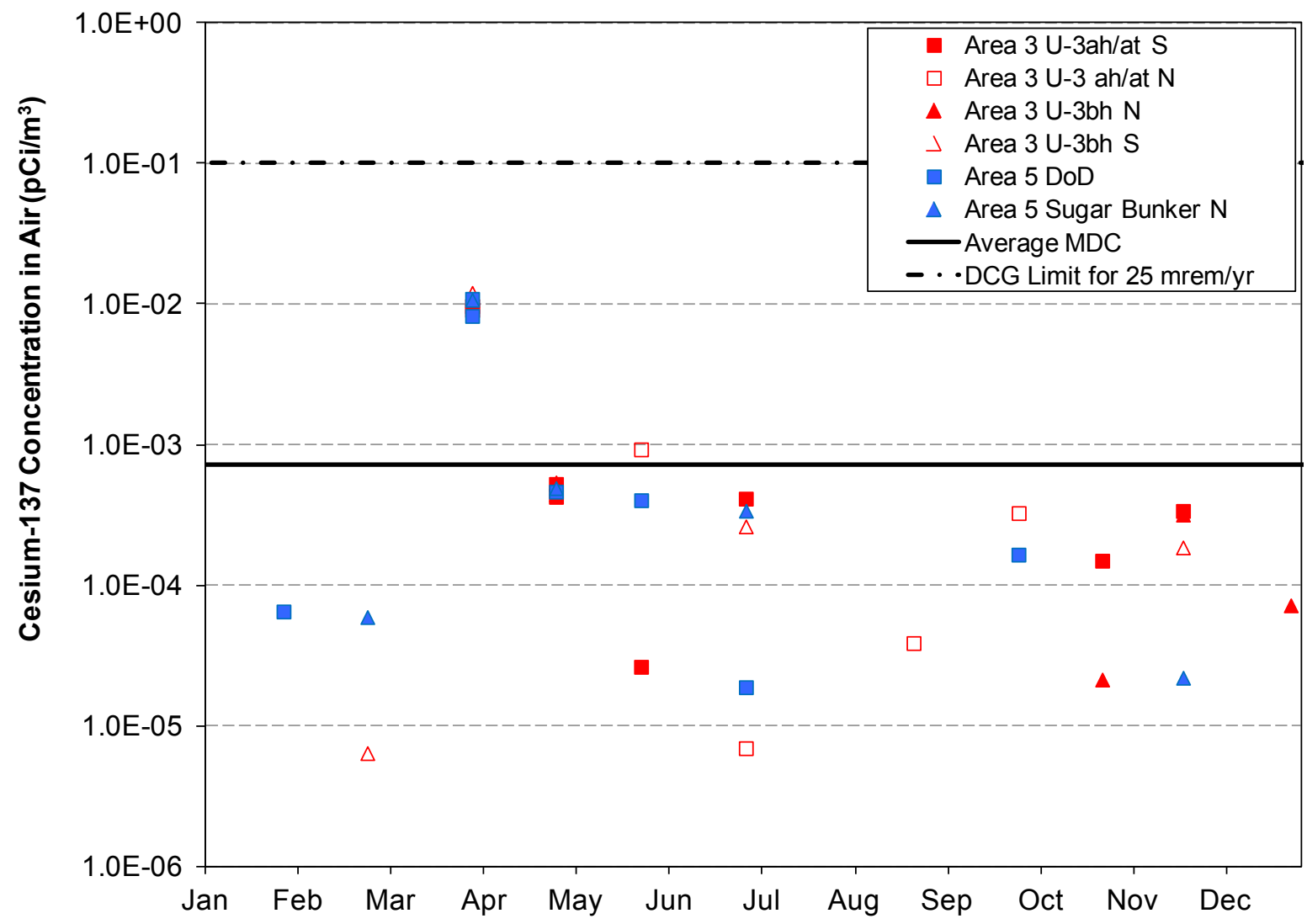

Figure 4-8. Concentration of ${ }^{137} \mathrm{Cs}$ in Air at the Area 3 and Area 5 RWMS during 2011

\subsubsection{Radon}

The performance objective from DOE Manual DOE M 435.1-1, "Radioactive Waste Management Manual," for radon emissions from DOE radioactive waste facilities is 20 picocuries per square meter per second ( $\left.\mathrm{pCi} / \mathrm{m}^{2} / \mathrm{s}\right)$. Radon fluxes were measured at the Area $3 \mathrm{RWMS} \mathrm{U-3ax/bl} \mathrm{cover}$ and at an undisturbed site outside the Area 3 RWMS for a control during 2011(Figure 4-9). Measurements were collected February 3-10, 2011, using radon flux domes (Rad Elec, Inc.) placed on the ground surface. Electrets inserted in the domes are electrically discharged by 
ionization of air from radon. The amount of discharge is correlated with radon flux from the ground.

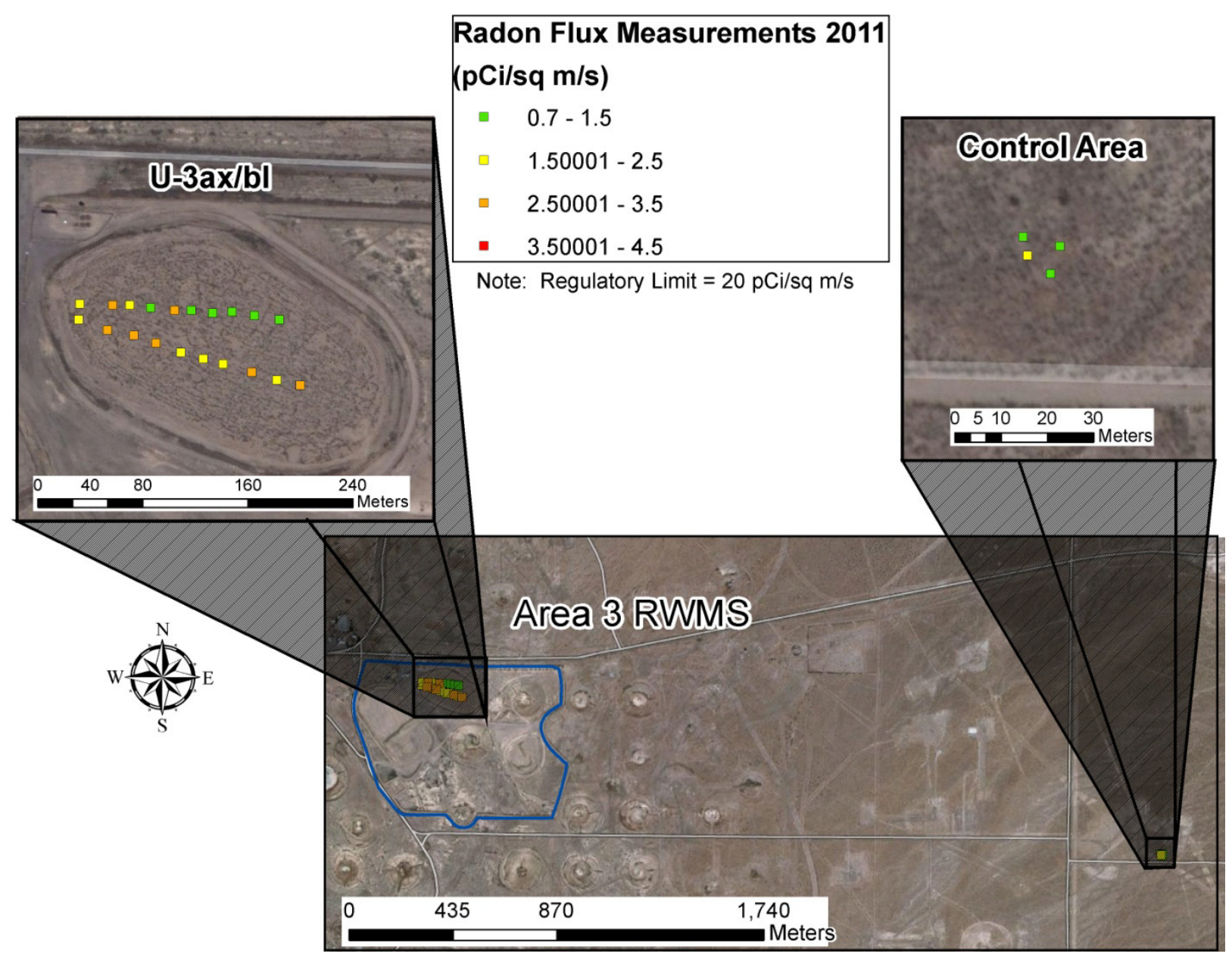

Figure 4-9. Radon Flux Measurement Location in Area 3

Radon flux results taken on both the Area 3 and Area 5 RWMSs over the past 10 years are summarized in Figure 4-10. Radon fluxes through the soil surface remained relatively low. All radon flux results were at least 5 times lower than the regulatory limit, and there are no apparent trends. 


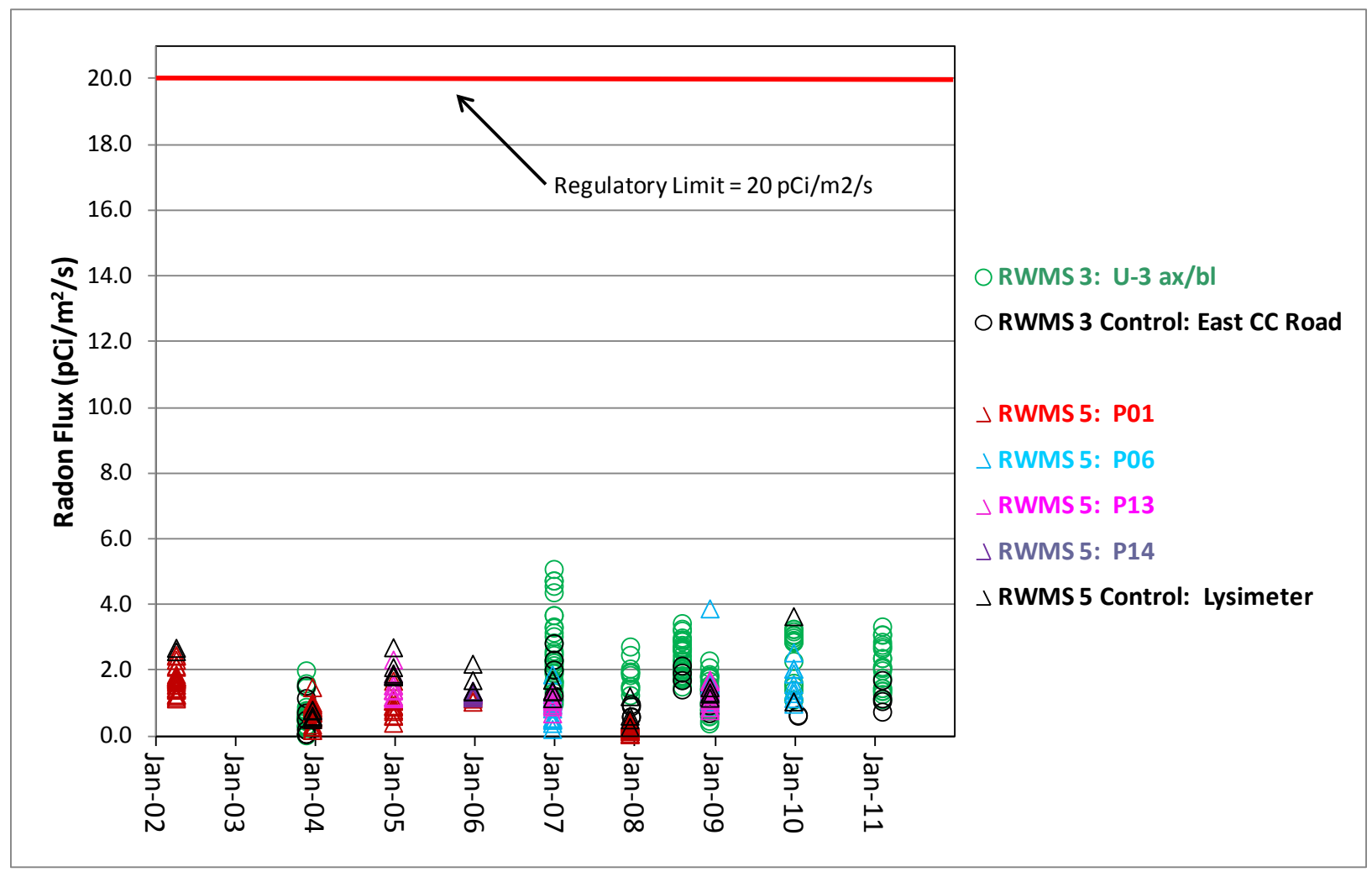

Figure 4-10. Radon Flux Results from 2002 through 2011

\subsection{GROUNDWATER MONITORING DATA}

Three wells (UE5PW-1, UE5PW-2, and UE5PW-3) were drilled around the perimeter of the Area 5 RWMS in 1993 (see Figure 3-2Figure 3-1). These wells are sampled twice a year to monitor the groundwater below the Area 5 RWMS. Initially groundwater samples were collected in March and August 2011, and resampling for TOC analysis was done in October 2011.

Investigation levels (ILs) have been established for five indicators of contamination migration. The measured indicators are SC, pH, TOC, TOX, and tritium. Further groundwater analyses are required if any analyte exceeds its IL. Initial TOC results from August 2011 were above previous results and highly variable among replicate samples. After disinfecting the pumps and sample tubing with a Clorox solution, the wells were resampled for TOC in October 2011. Results from 2011 are summarized in Table 4-1. General water chemistry parameters are also measured.

To date, all analytical data from groundwater sampling events from the wells indicate that the groundwater in the uppermost aquifer is unaffected by activities at the Area 5 RWMS. Detailed information and data on the groundwater monitoring program at the Area 5 RWMS are presented in the Nevada National Security Site 2011 Data Report: Groundwater Monitoring Program, Area 5 Radioactive Waste Management Site (NSTec, 2012b). 
Table 4-1. Investigation Levels and Results from 2011 Groundwater Monitoring

\begin{tabular}{||ccc||}
\hline $\begin{array}{c}\text { Indicator } \\
\text { Parameter }\end{array}$ & $\begin{array}{c}\text { Investigation } \\
\text { Level }\end{array}$ & Results \\
\hline $\mathrm{pH}$ & $<7.6$ or $>9.2$ & 8.22 to 8.39 \\
$\mathrm{SC}$ & $0.440 \mathrm{mmhos} / \mathrm{cm}$ & 0.358 to $0.381 \mathrm{mmhos} / \mathrm{cm}$ \\
TOC & $1 \mathrm{mg} / \mathrm{L}$ & $<0.5$ to $0.59 \mathrm{mg} / \mathrm{L}$ \\
TOX & $50 \mu \mathrm{g} / \mathrm{L}$ & $<5$ to $<13.3 \mu \mathrm{g} / \mathrm{L}$ \\
Tritium & $2,000 \mathrm{pCi} / \mathrm{L}$ & -3.17 to $2.97 \mathrm{pCi} / \mathrm{L}$ \\
\hline
\end{tabular}

Units are millimhos per centimeter (mmhos/cm), milligrams per liter $(\mathrm{mg} / \mathrm{L})$, micrograms per liter $(\mu \mathrm{g} / \mathrm{L})$, and picocuries per liter $(\mathrm{pCi} / \mathrm{L})$.

Groundwater elevation is measured quarterly using an electronic tape. All groundwater elevation data since the wells were drilled in 1993 are shown in Figure 4-11. The 2011 average depths to groundwater from the top of casing are $235.85 \mathrm{~m}(773.78 \mathrm{ft})$ at UE5PW-1, $256.48 \mathrm{~m}$ $(841.47 \mathrm{ft})$ at UE5PW-2, and $271.56 \mathrm{~m}(890.94 \mathrm{ft})$ at UE5PW-3. The average groundwater elevations are $733.52 \mathrm{~m}(2406.55 \mathrm{ft}) \mathrm{AMSL}$ at UE5PW-1, $733.64 \mathrm{~m}(2406.94 \mathrm{ft}) \mathrm{AMSL}$ at UE5PW-2, and $733.66(2407.01 \mathrm{ft})$ AMSL at UE5PW-3. These data indicate that the water table beneath the Area 5 RWMS is flat, with little or no groundwater flow. Estimated groundwater flow velocity is less than $0.08 \mathrm{~m} /$ year $(0.26 \mathrm{ft} / \mathrm{year})$ to the south.

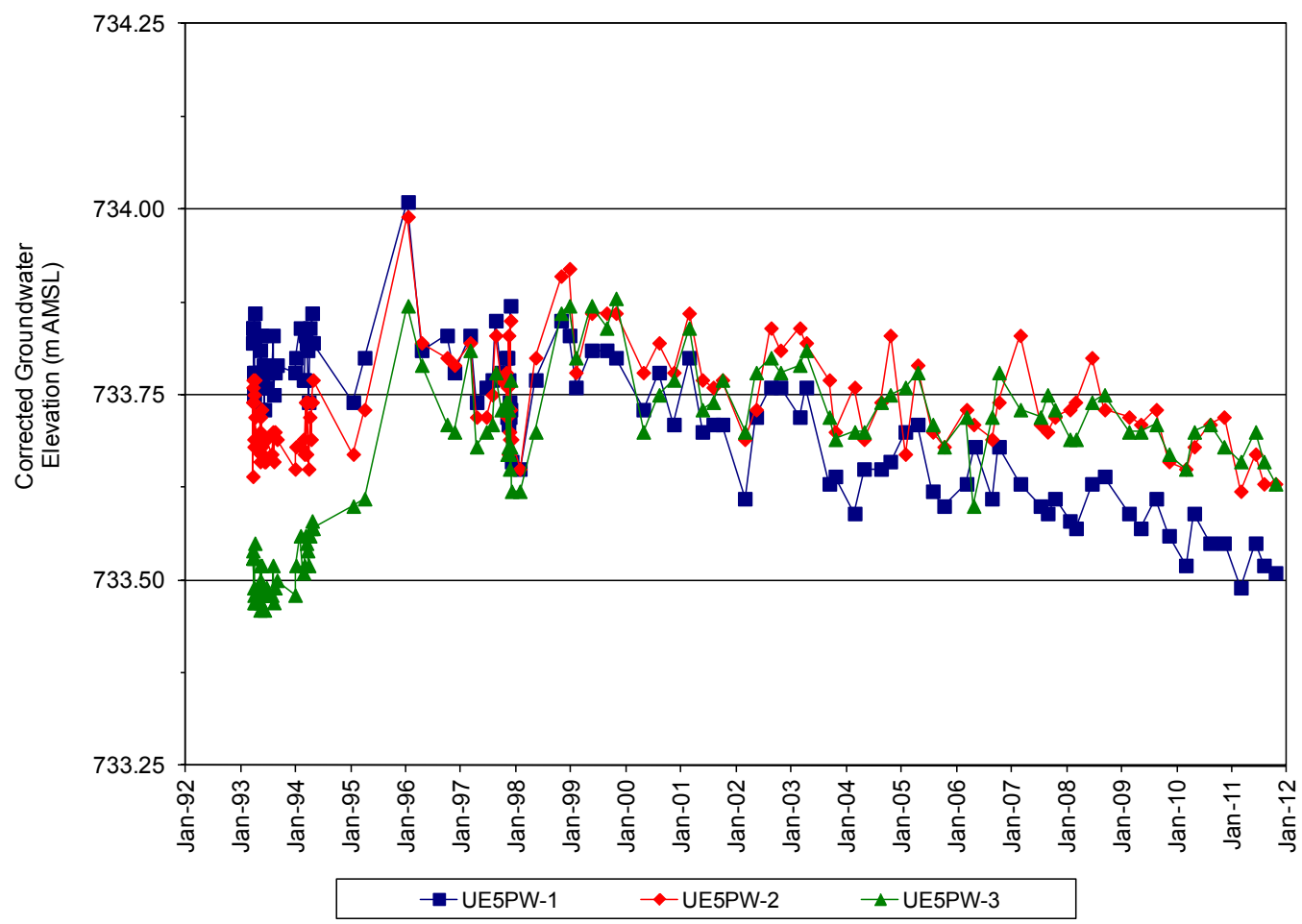

Figure 4-11. Groundwater Elevation at the Three Area 5 RWMS Pilot Wells 


\subsection{METEOROLOGY MONITORING DATA}

Meteorology monitoring data collected in 2011 include precipitation, air temperature, humidity, wind speed and direction, barometric pressure, and incoming solar radiation. These are basic meteorological parameters required to quantify the exchange of water and heat between the soil and the atmosphere. These data were collected from two meteorology stations, one located approximately $30 \mathrm{~m} \mathrm{(100} \mathrm{ft)} \mathrm{northwest} \mathrm{of} \mathrm{the} \mathrm{Area} 3 \mathrm{RWMS}$, and one near the Area $5 \mathrm{RWMS}$ about $100 \mathrm{~m}$ (328 ft) north from Well UE5PW-1 (see Figure 3-1 and Figure 3-2).

\subsubsection{Air Temperature}

Air temperatures at the Area 3 RWMS are slightly cooler than air temperatures at the Area 5 RWMS. The 2011 average recorded temperatures at $3 \mathrm{~m}(10 \mathrm{ft})$ are $12.9^{\circ} \mathrm{C}\left(55.2^{\circ} \mathrm{F}\right)$ at the Area 3 RWMS and $15.1^{\circ} \mathrm{C}\left(59.2^{\circ} \mathrm{F}\right)$ at the Area 5 RWMS. The 2011 maximum and minimum temperatures at $3 \mathrm{~m}(10 \mathrm{ft})$ are $38.3^{\circ} \mathrm{C}\left(100.9^{\circ} \mathrm{F}\right)$ on July 2,2011 , and $-13.1^{\circ} \mathrm{C}\left(8.4^{\circ} \mathrm{F}\right)$ on January 1,2011 , at the Area $3 \mathrm{RWMS}$ and $41.2^{\circ} \mathrm{C}\left(106.2^{\circ} \mathrm{F}\right)$ on July 2,2011 , and $-12.1^{\circ} \mathrm{C}$ $\left(10.2^{\circ} \mathrm{F}\right)$ on December 6, 2011, at the Area 5 RWMS (Figure 4-12).

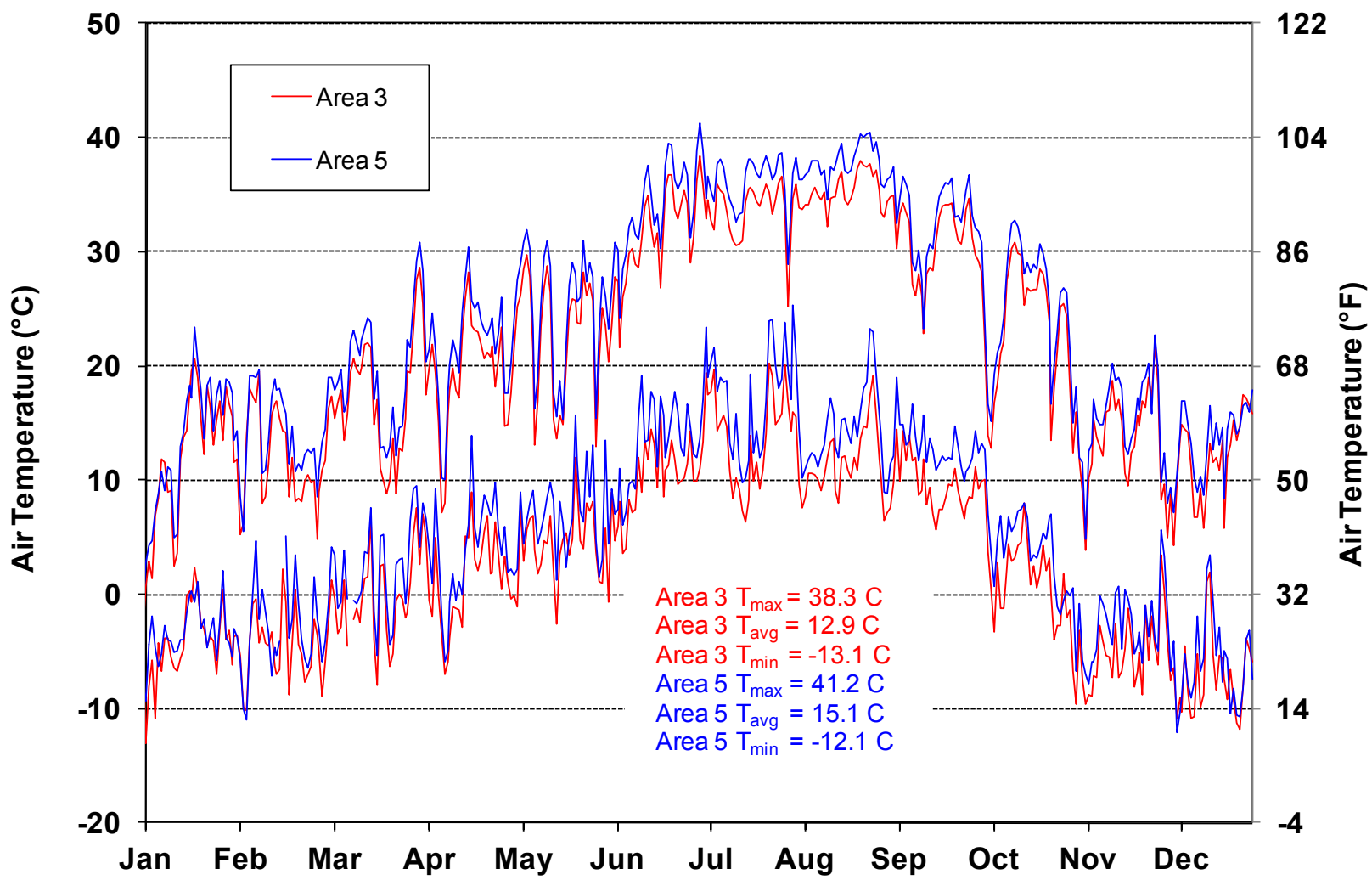

Figure 4-12. Daily Maximum and Minimum Temperature at the Area 3 and Area 5 RWMSs

\subsubsection{Relative Humidity}

Measured relative humidity at the Area 3 RWMS and the Area 5 RWMS is similar. The daily average relative humidity during 2011 at these two sites is $35.5 \%$ for Area 3 and $34.6 \%$ for Area 5 (Figure 4-13). Measured daily average relative humidity ranged from $8.8 \%$ to $96.8 \%$. 


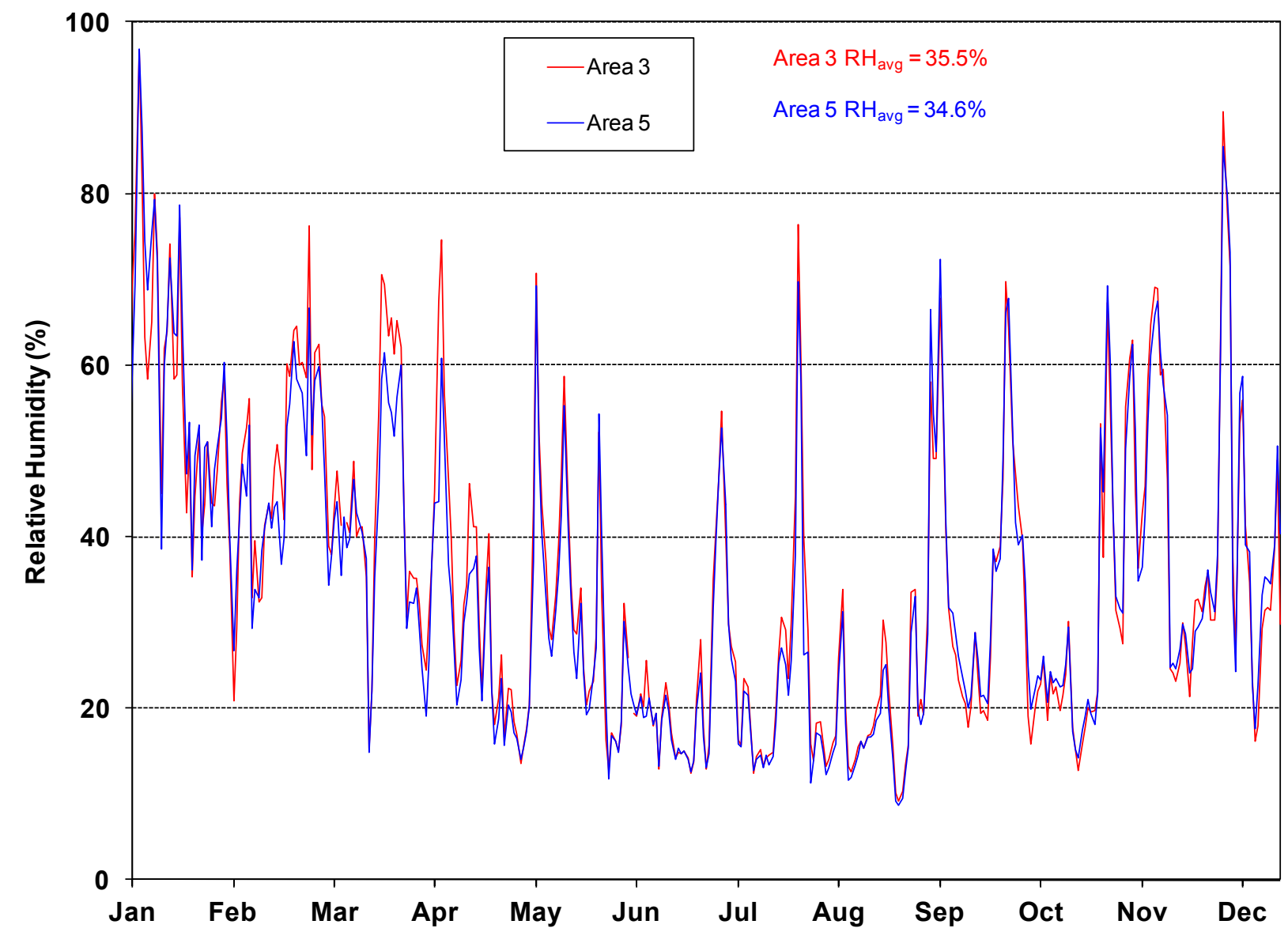

Figure 4-13. Daily Average Relative Humidity at the Area 3 and Area 5 RWMSs

\subsubsection{Barometric Pressure}

Average daily barometric pressure measured at the Area 3 RWMS and the Area 5 RWMS show very similar patterns (Figure 4-14). The average barometric pressure at the Area 3 RWMS is 87.8 kilopascals $(\mathrm{kPa})$ (12.73 pounds per square inch [PSI]), and the average barometric pressure at the Area 5 RWMS is $90.4 \mathrm{kPa}(13.11 \mathrm{PSI})$. The difference in barometric pressure

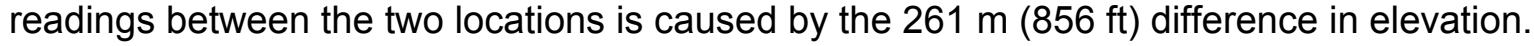




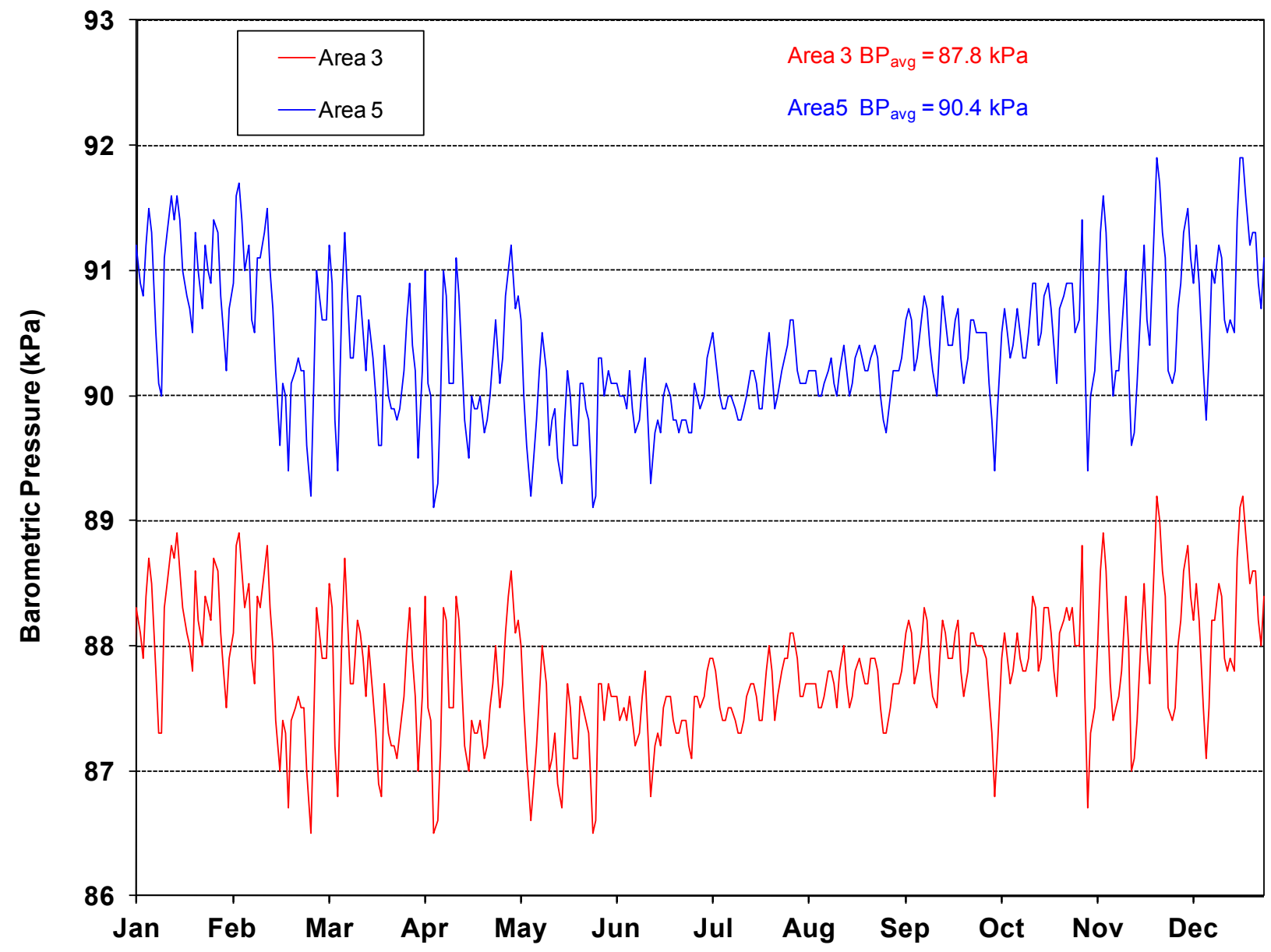

Figure 4-14. Average Barometric Pressure at the Area 3 and Area 5 RWMSs

\subsubsection{Wind Speed and Wind Direction}

The average wind speed is slightly higher at the Area 3 RWMS than at the Area 5 RWMS. During 2011, the average daily wind speed at the Area 3 RWMS was $3.1 \mathrm{~m} / \mathrm{s}(6.9 \mathrm{mph})$, and the maximum gust was $20.9 \mathrm{~m} / \mathrm{s}$ (46.8 mph) on March 7. During 2011, the average daily wind speed at the Area 5 RWMS was $3.2 \mathrm{~m} / \mathrm{s}(7.2 \mathrm{mph})$, and the maximum gust was $23.3 \mathrm{~m} / \mathrm{s}$ (52.1 mph) on November 30. Daily maximum and average wind speeds are in Figure 4-15 and Figure 4-16.

Wind rose diagrams illustrate wind direction and wind speed distribution in each direction using hourly wind data measured at a height of $3 \mathrm{~m} \mathrm{AGL}$. Generally, more wind comes from the north and higher wind speeds come from the south. Wind roses from the Area 3 and Area 5 RWMSs are presented in Figure 4-17 and Figure 4-18, respectively. The 1-year wind roses presented here are very similar to the multiple-year wind roses. 


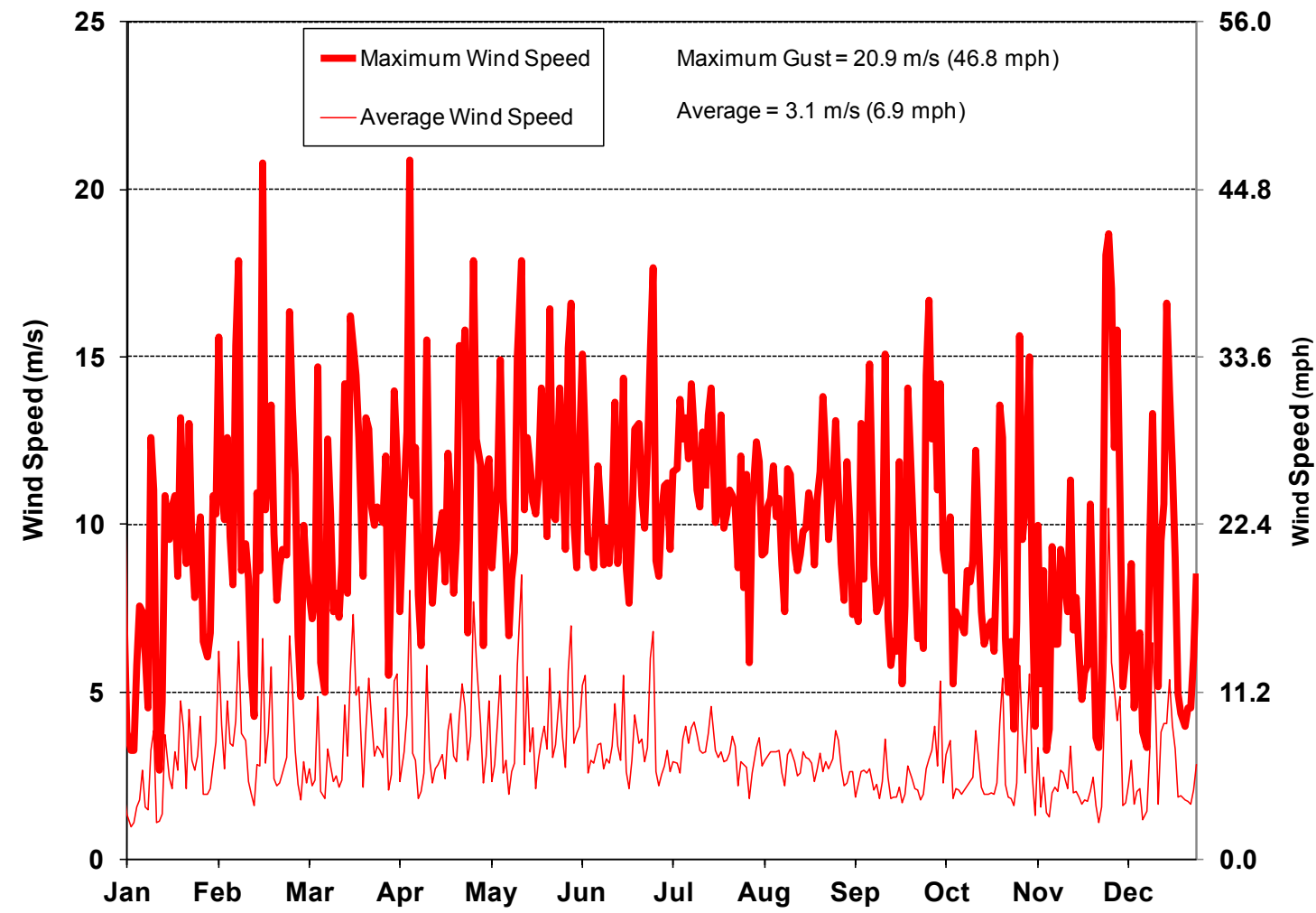

Figure 4-15. Daily $3 \mathrm{~m}$ Wind Speed at the Area 3 RWMS

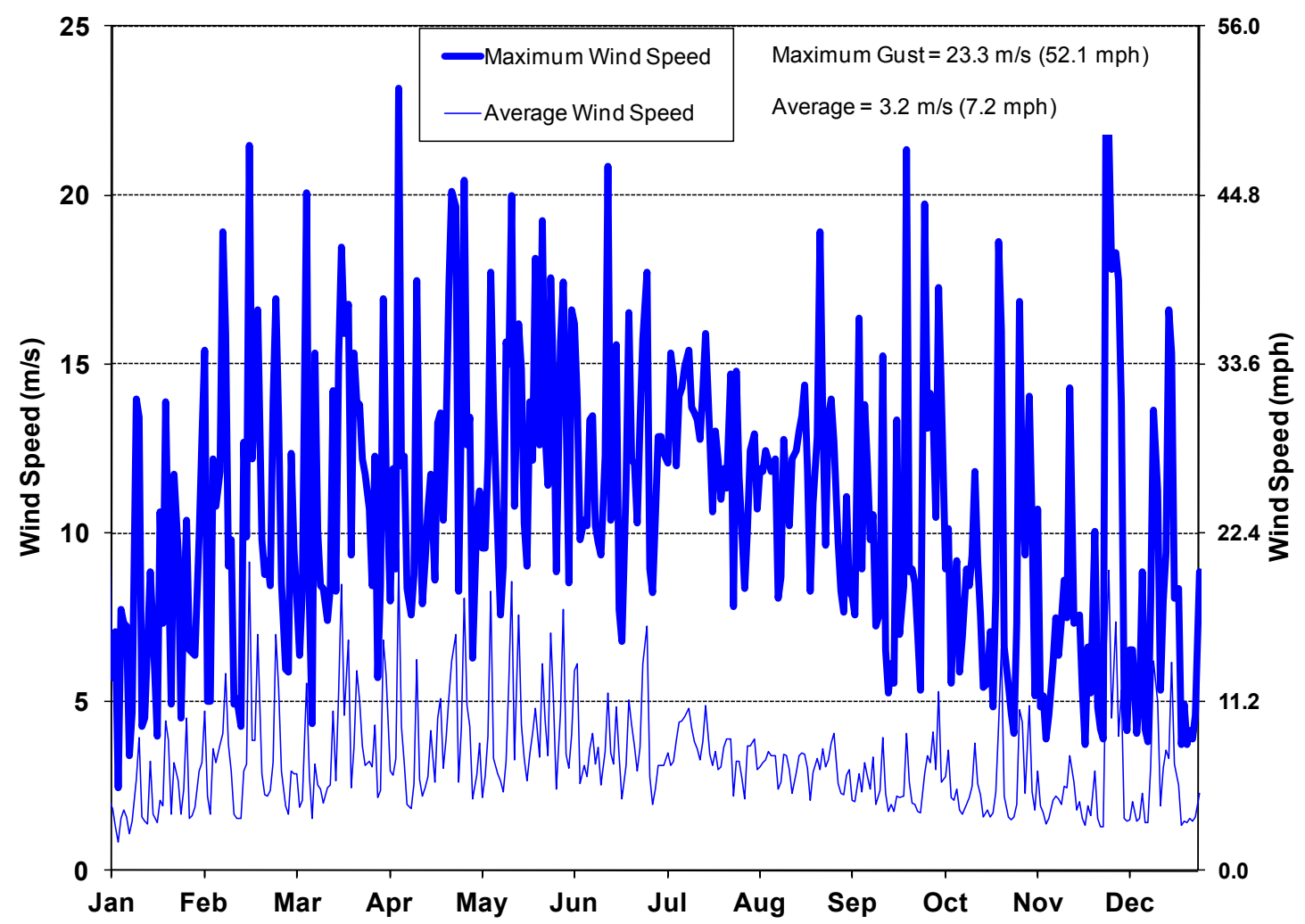

Figure 4-16. Daily $3 \mathrm{~m}$ Wind Speed at the Area 5 RWMS 


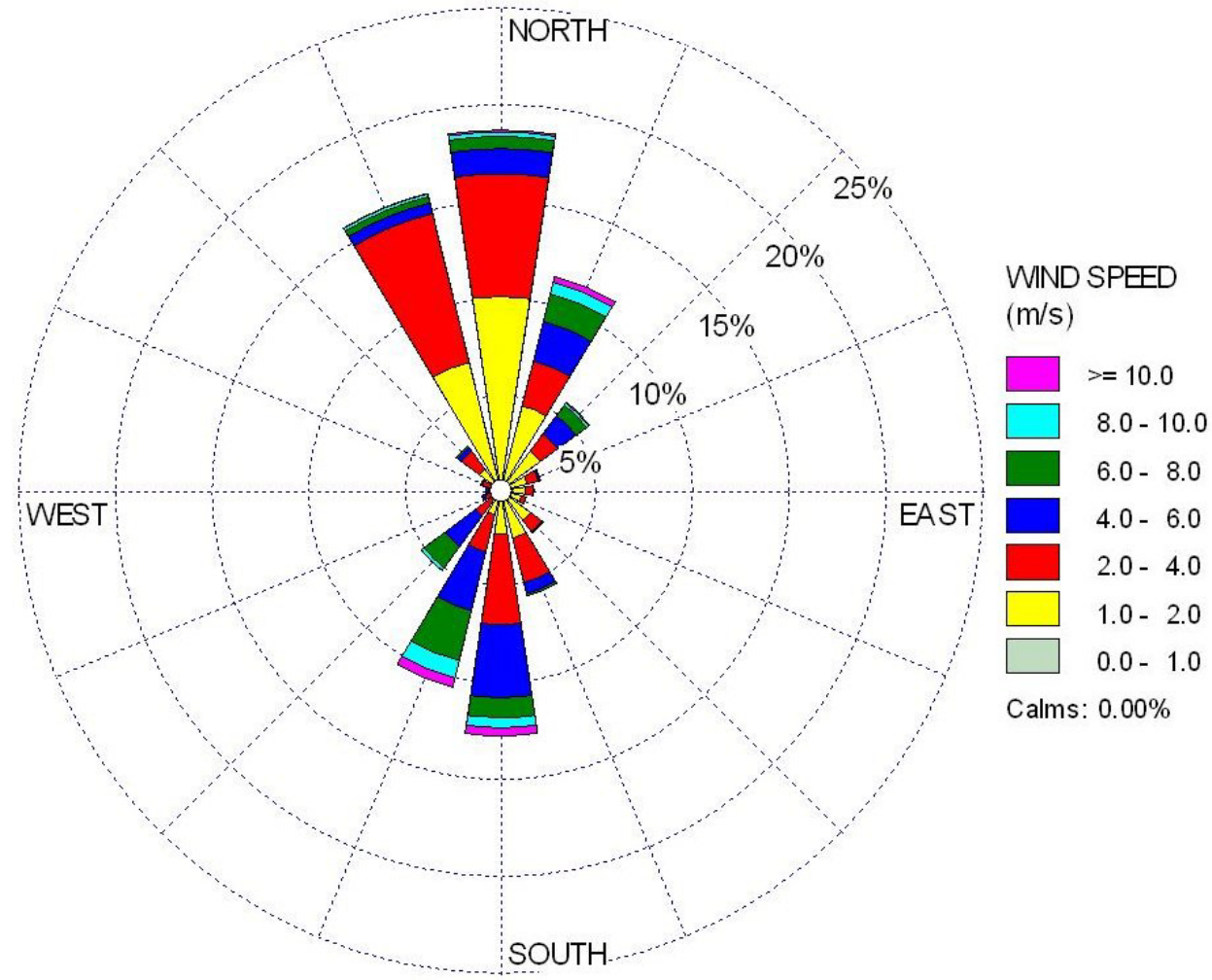

Figure 4-17. Wind Rose Diagram for the Area 3 RWMS

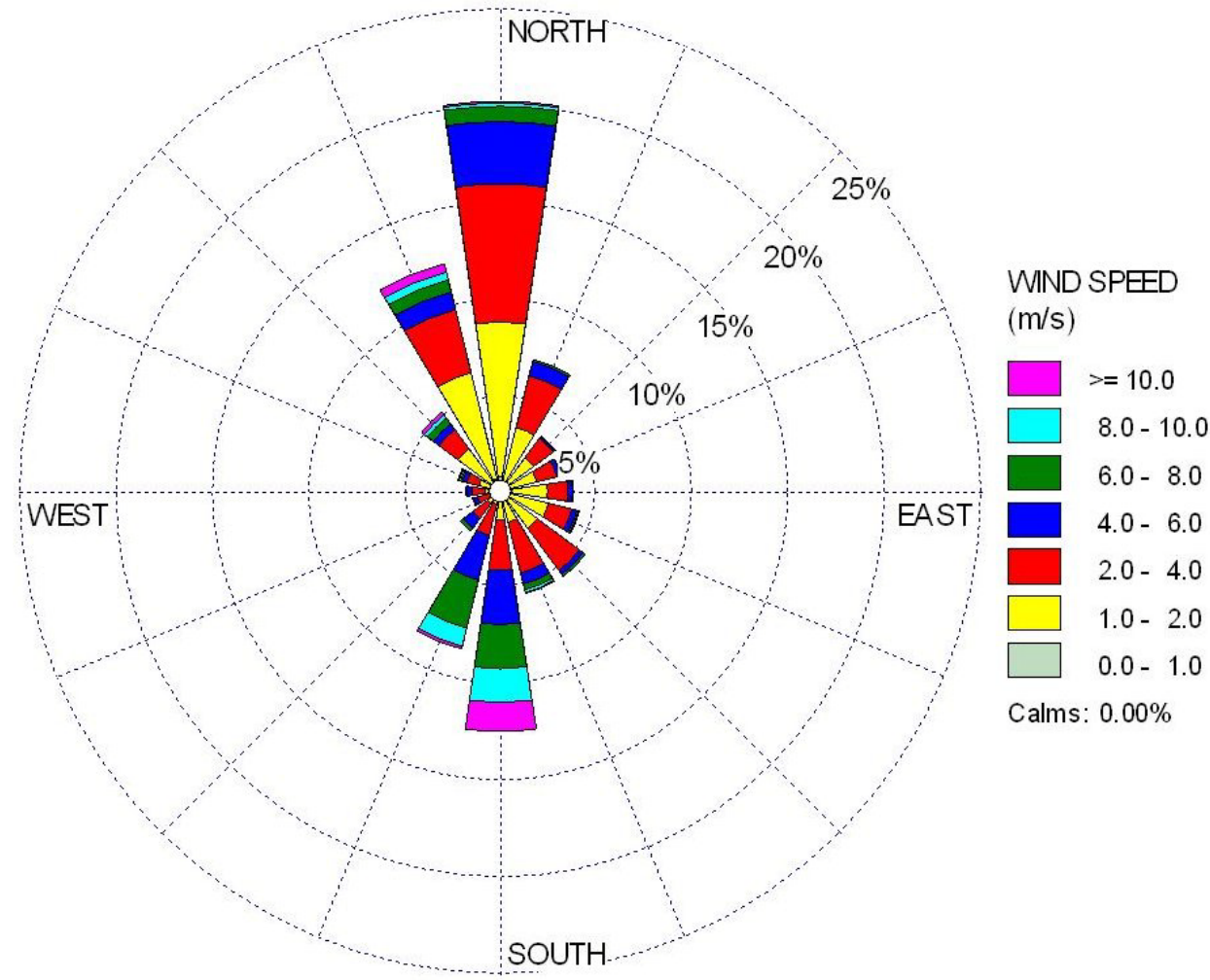

Figure 4-18. Wind Rose Diagram for the Area 5 RWMS 


\subsubsection{Precipitation}

Rainfall at the Area 3 RWMS in 2011 was $44 \%$ below average, totaling $86.3 \mathrm{~mm}$ (3.40 in.). This is the second driest year since measurements began at the Area 3 RWMS in 1996. Only 2002 had less precipitation. The average annual precipitation measured at the Area 3 RWMS from 1996 to 2011 is $154.1 \mathrm{~mm}$ (6.07 in.). The maximum daily rainfall at the Area 3 RWMS during 2011 was $9.4 \mathrm{~mm}$ (0.37 in.) on May 9. Precipitation was measured on 37 days during 2011 at the Area 3 RWMS (Figure 4-19).

Rainfall at the Area 5 RWMS in 2011 was $47 \%$ below average, totaling $64.8 \mathrm{~mm}$ (2.55 in.). This is the third driest year since measurements began at the Area 5 RWMS in 1995. The average annual precipitation measured at the Area 5 RWMS from 1995 to 2011 is $122.4 \mathrm{~mm}$ (4.82 in.). The maximum daily rainfall at the Area 5 RWMS during 2011 was $17.9 \mathrm{~mm}$ (0.70 in.) on September 11. Precipitation was measured on 31 days during 2011 at the Area 5 RWMS (Figure 4-20).

Historical precipitation data recorded at BJY (located about $3 \mathrm{~km}$ [2 mi] northwest of the Area 3 RWMS) and at the Area 3 RWMS are in Figure 4-21. The BJY station is a Meteorological Data Acquisition (MEDA) station operated by ARL/SORD. The 51-year average annual precipitation at BJY from 1961 to 2011 is $160.5 \mathrm{~mm}$ (6.32 in.). Historical precipitation data recorded at the Well 5B station (located about $5.5 \mathrm{~km}$ [3.4 mi] south of the Area 5 RWMS) and at the Area 5 RWMS are provided in Figure 4-22. The Well 5B station is also an ARL/SORD MEDA station. The 49-year average annual precipitation at Well 5B from 1963 to 2011 is $122.4 \mathrm{~mm}$ (4.82 in.).

\subsubsection{Reference Evapotranspiration}

The calculated $2011 \mathrm{ET}_{\text {ref }}$ at the Area 3 RWMS is $1,581 \mathrm{~mm}$ (62.2 in.) and at the Area 5 RWMS is $1,566 \mathrm{~mm}$ (61.6in.). $\mathrm{ET}_{\text {ref }}$ is the rate that readily available soil water is vaporized from a uniform surface of dense, actively growing vegetation. Crop coefficients are used to convert $E T_{\text {ref }}$ to potential evapotranspiration rates (Allen et al., 2005). $E T_{\text {ref }}$ is calculated using a modified version of the radiation-based equation of Doorenbos and Pruitt (1977). The equation calculates $\mathrm{ET}_{\text {ref }}$ from hourly measurements of solar radiation, air temperature, relative humidity, wind speed, and barometric pressure. This method provides results similar to the Penman Equation that was previously used for the data reports through 2001 (Campbell, 1977). The Doorenbos and Pruitt equation reduces data input requirements because no net radiation data are used. The ratio of $\mathrm{ET}_{\text {ref }}$ to precipitation in 2011 at the Area $3 \mathrm{RWMS}$ is 18.3 , and the ratio $\mathrm{ET}_{\text {ref }}$ to precipitation in 2011 at the Area 5 RWMS is 24.2. The high ratio of $E_{\text {ref }}$ to precipitation during 2011 is caused by the very low precipitation. 


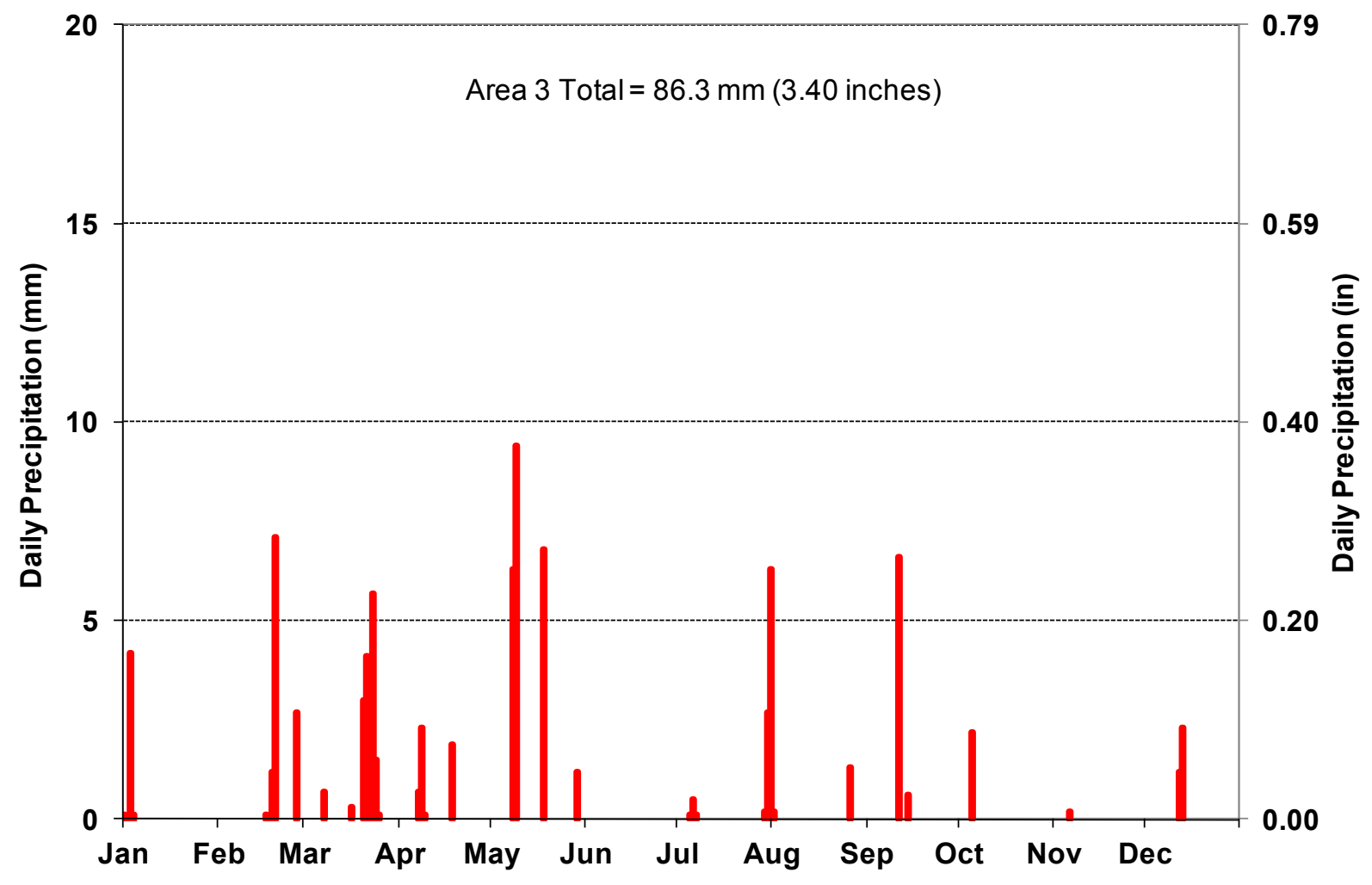

Figure 4-19 Daily Precipitation at the Area 3 RWMS

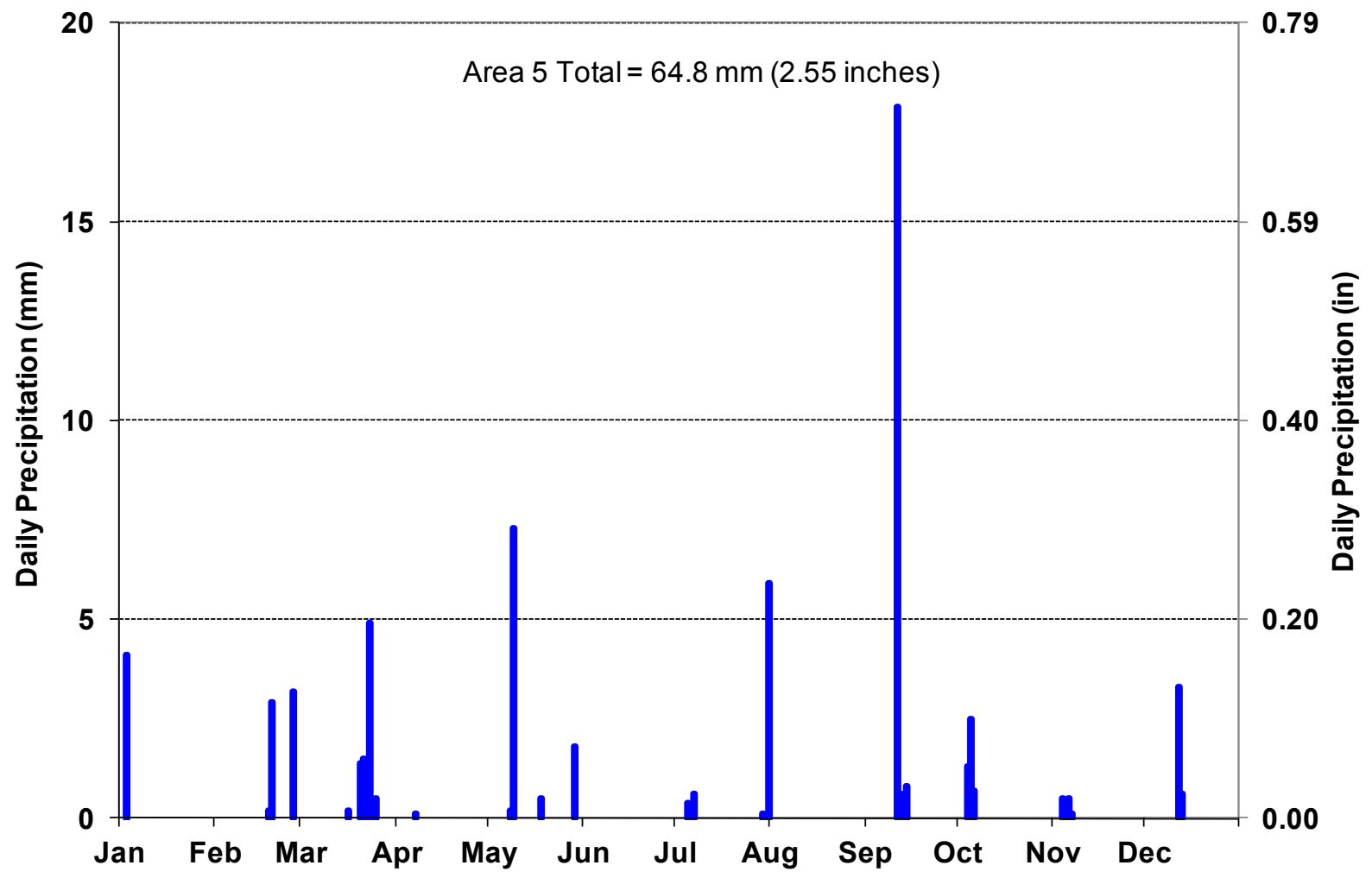

Figure 4-20 Daily Precipitation at the Area 5 RWMS 


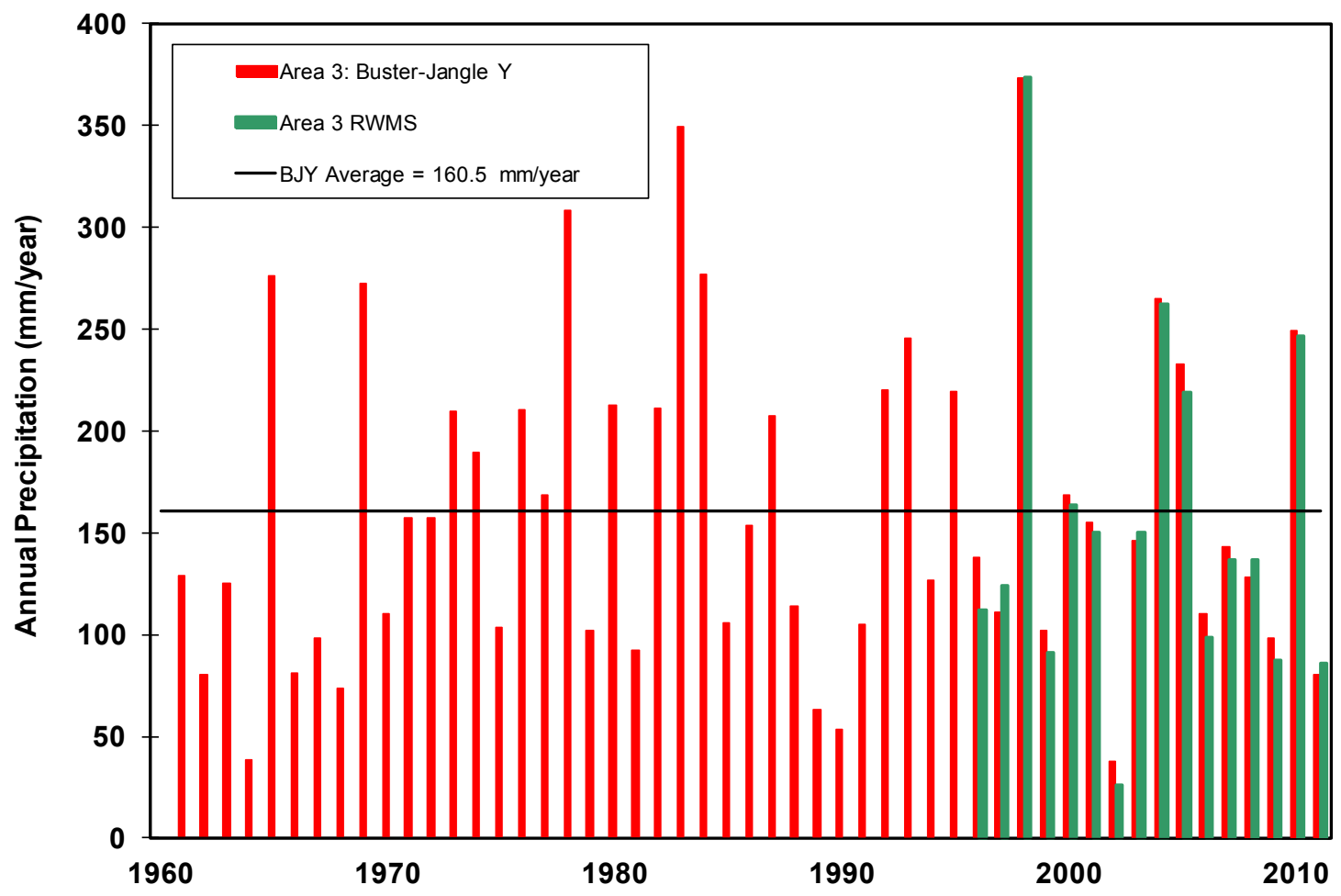

Figure 4-21. Historical Precipitation Record for the Buster-Jangle $Y$ and the Area 3 RWMS

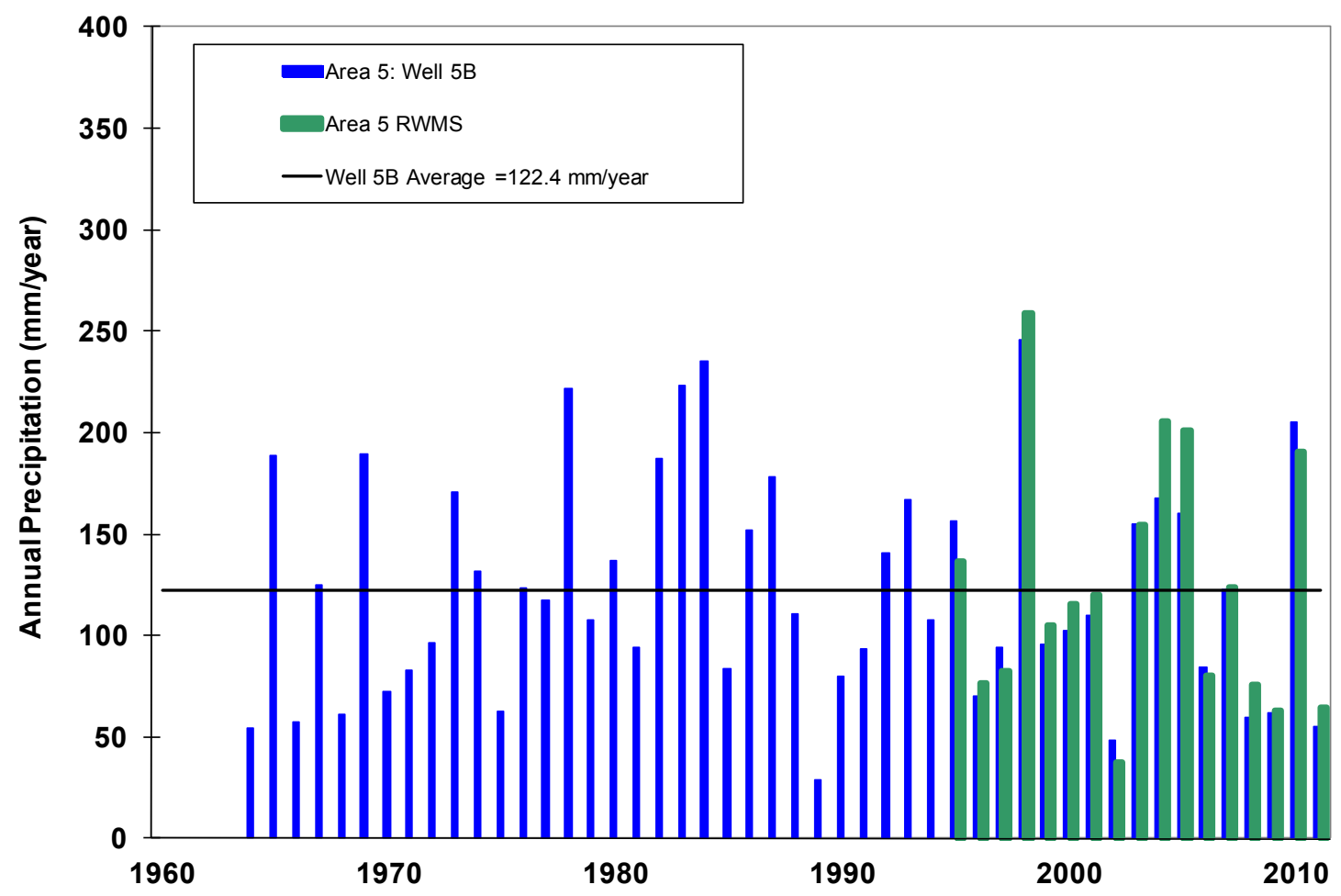

Figure 4-22. Historical Precipitation Record for Well 5B and Area 5 RWMS 


\subsection{VADOSE ZONE MONITORING DATA}

\subsubsection{Monitoring Strategy}

Vadose zone monitoring is conducted at the Area 3 and Area 5 RWMSs to demonstrate compliance with DOE O 435.1 and confirm the assumptions in the PA for each RWMS (e.g., hydrologic conceptual models, including soil water contents, flux rates and directions, and volatile radionuclide releases). The vadose zone monitoring is also performed to detect changing trends in performance, provide added assurance to PA conclusions regarding facility performance, evaluate the performance of the operational monolayer waste covers, and confirm the PA performance objective of protecting groundwater resources.

The design of the current vadose zone monitoring program at the RWMSs is based on an understanding of the vadose zone system acquired through extensive characterization studies (BN, 1998; 2005a; 2005b; Blout et al., 1995; Reynolds Electrical \& Engineering Co., Inc., 1993a; 1993b; Shott et al., 1997; 1998; Tyler et al., 1996) and modeling studies (Levitt et al., 1999; Desotell et al., 2006; 2007). The objectives of the vadose zone monitoring program are accomplished, in part, by measuring water balances at each RWMS. Water balance studies involve using meteorology data to calculate $\mathrm{ET}_{\text {ref }}$ values (the driving force of upward flow), directly measuring ET and bare-soil E at the RWMS lysimeter facilities, and measuring soil water content and soil water potential in waste cell covers and floors using automated waste cover monitoring systems.

\subsubsection{Soil Gas Tritium}

Soil gas tritium monitoring was discontinued. The last samples were collected in June 2010, and the GCD boreholes were backfilled during construction of the ET cover on the 92-Acre Area.

\subsubsection{Area 5 Weighing Lysimeter Facility}

The Area 5 Weighing Lysimeter Facility consists of two precision weighing lysimeters located about $400 \mathrm{~m}(1,312 \mathrm{ft})$ southwest of the Area 5 RWMS (see Figure 3-2). Each lysimeter is an open-top steel box, measuring $2 \mathrm{~m}$ wide by $4 \mathrm{~m}$ long by $2 \mathrm{~m}$ deep $(6.6 \mathrm{ft}$ wide by $13 \mathrm{ft}$ long by $6.6 \mathrm{ft}$ deep), filled with soil and mounted on a sensitive scale. Weight changes of each lysimeter are continuously monitored using an electronic load cell. Each load cell can measure approximately $0.1 \mathrm{~mm}$ (0.004 in.) of precipitation or ET. One lysimeter is vegetated with the native plant species Larrea tridentata (creosote bush), Lycium andersonii (Anderson's wolfberry), and Schismus arabicus (Arabian schismus) at the approximate density of the surrounding desert. The other lysimeter is kept bare to simulate the bare operational waste covers at the Area 5 RWMS. The lysimeters have provided surface water balance data at the Area 5 RWMS since March 1994.

The weighing lysimeter data represent a simplified water balance: the change in soil water storage is equal to precipitation minus $\mathrm{E}$ (on bare lysimeters) or ET (on vegetated lysimeters). The water balance is simplified because no drainage can occur through the solid bottoms of the lysimeters and because a 2.5 centimeter $(\mathrm{cm})(1 \mathrm{in}$.) lip around the edge of the lysimeters prevents run-on and runoff. Total soil water storage for the period of March 30, 1994, through December 31, 2011, is provided in Figure 4-23.

The vegetated lysimeter is considerably drier than the bare-soil lysimeter despite the small number of plants on the vegetated lysimeter (about $27 \%$ plant cover). The average soil water 
storage depth in the vegetated lysimeter from January 1, 1996, to December 31, 2011, is $117 \mathrm{~mm}$ (4.6 in.). This is equivalent to an average VWC of 5.8\%. For the same period, the average soil water storage depth in the bare lysimeter is $209 \mathrm{~mm}$ (8.2 in.), which is equivalent to an average VWC of $10.4 \%$. During 2011 , the average soil water storage depth in the vegetated lysimeter was $144 \mathrm{~mm}$ (5.7 in.), and the average water storage depth in the bare lysimeter was $245 \mathrm{~mm}$ (9.6 in.).

Following high rainfall periods in the winter, soil water storage decreases in the vegetated lysimeter due to ET from rapid plant growth in the spring. As the vegetated lysimeter dries out, plant growth and ET slow. Eventually E from the bare lysimeter exceeds ET from the vegetated lysimeter in the summer due to the higher water content in the bare lysimeter.

No water has ever accumulated at the bottom of the vegetated lysimeter. Heavy precipitation during the late fall and winter combined with low $E$ rates and higher initial water contents may result in water accumulation at the bottom of the bare lysimeter. A suction of $-8.0 \mathrm{kPa}(-1.2 \mathrm{PSI})$ was applied to the porous suction candles on the bottom of the bare lysimeter from May 5, 2008, to June 19, 2008; from March 2, 2009, to May 12, 2009; and from February 3, 2010, to April 27, 2010. No water effluent was collected from the suction candles during these periods. Long-term numerical simulations (30 years) using a unit gradient bottom boundary estimate the amount of drainage that would have occurred if water could drain from the lysimeters. These simulations indicate an average of $1.0 \mathrm{~cm}$ per year of water reaches the bottom of the bare lysimeter, and essentially no water reaches the bottom of the vegetated lysimeter (Desotell et al., 2006).

During 2011, E from the bare lysimeter was $113.0 \mathrm{~mm}$ (4.4 in.) and ET from the vegetated lysimeter was $145.5 \mathrm{~mm}$ (5.7 in.). Water contents in both lysimeters decreased in 2011 because both $\mathrm{E}$ and $\mathrm{ET}$ were greater than the $64.8 \mathrm{~mm}$ of precipitation. Monthly precipitation was less than ET except in September and December 2011, and monthly precipitation was less than E in every month except September 2011. ET was greater than E in January through July, and E was greater than ET in August through December (Figure 4-24 and Figure 4-25).

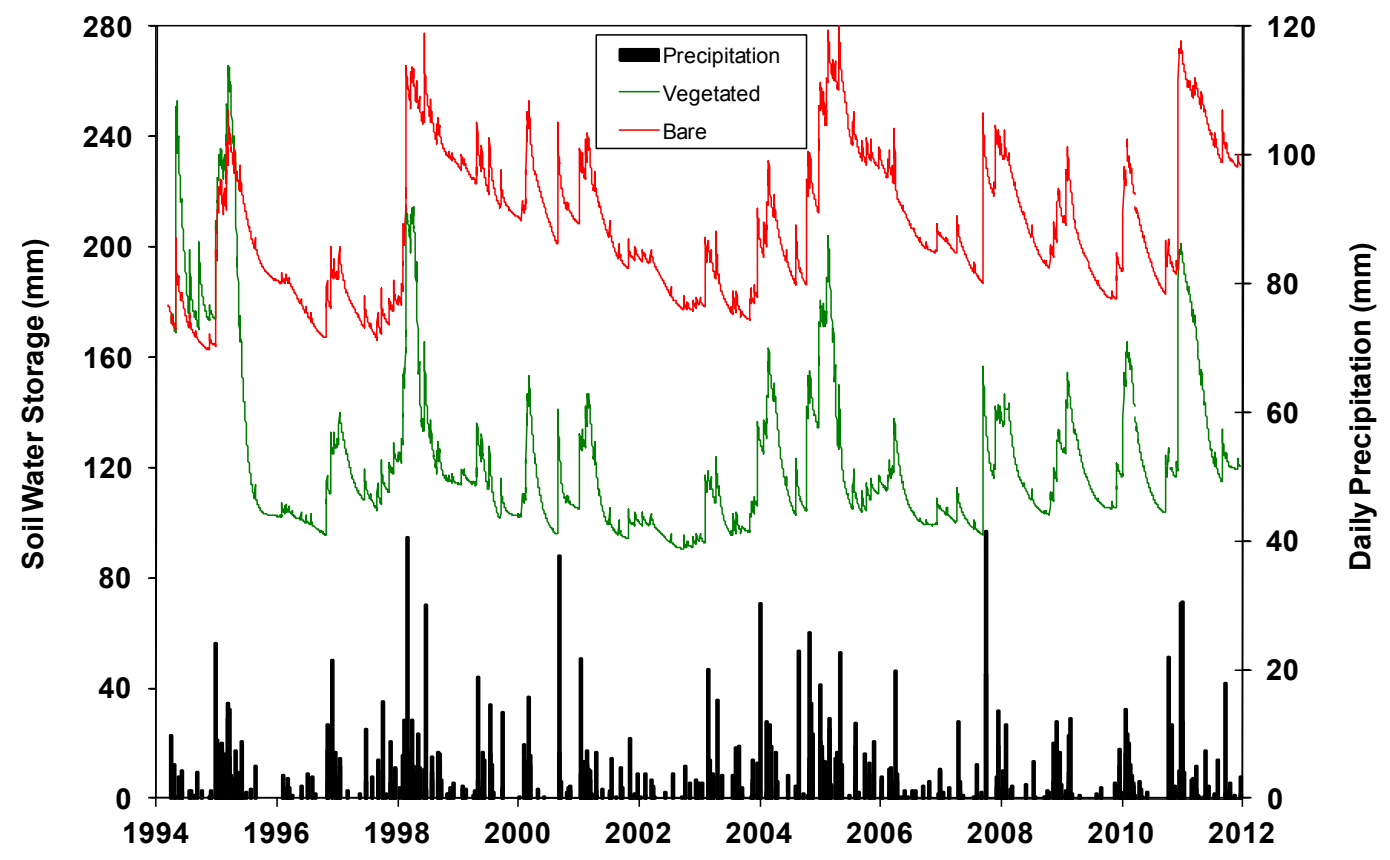

Figure 4-23. Weighing Lysimeter data from March 1994 to 2011 


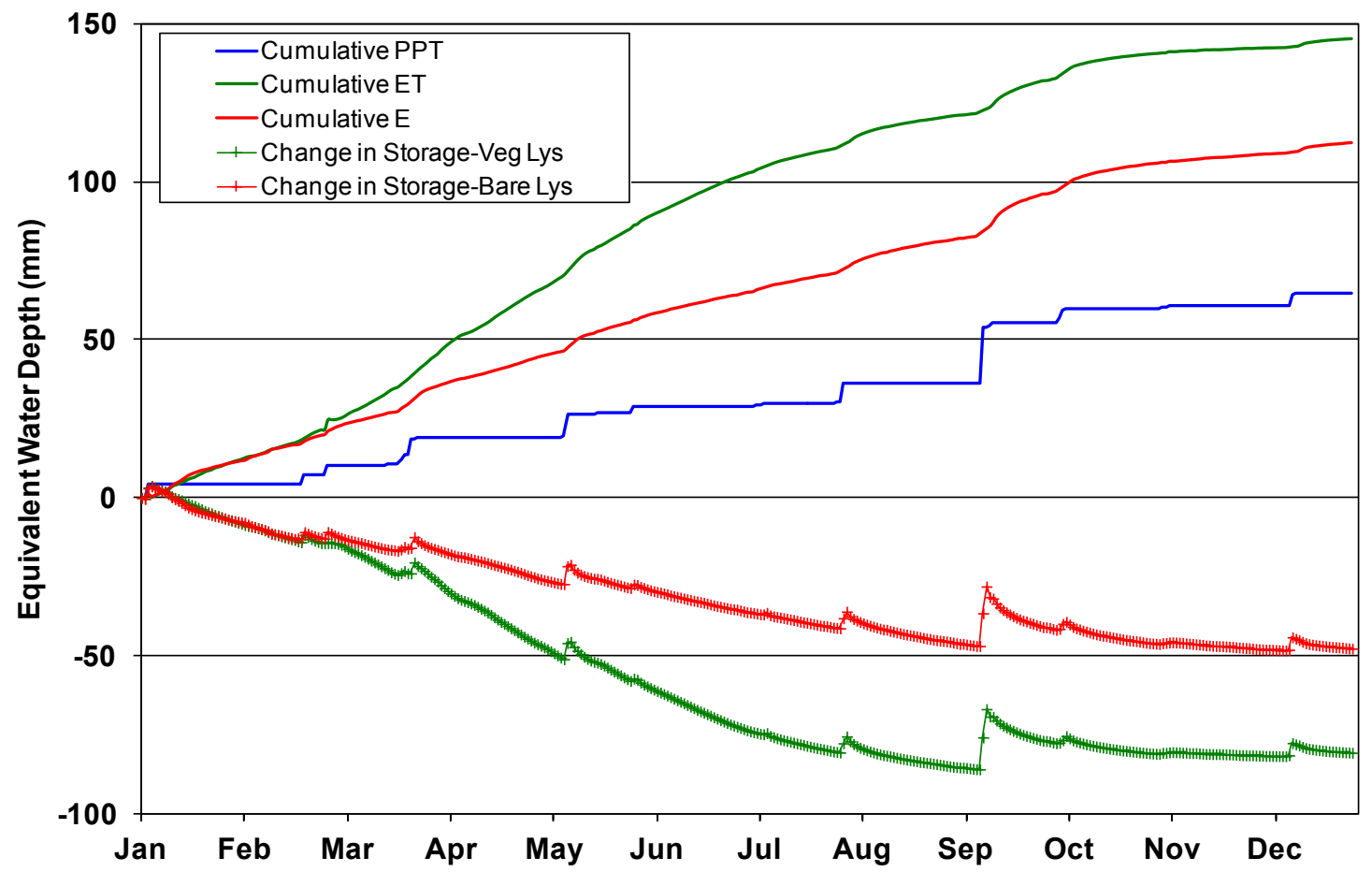

Figure 4-24. Precipitation, ET, E, and Storage for the Weighing Lysimeters during 2011

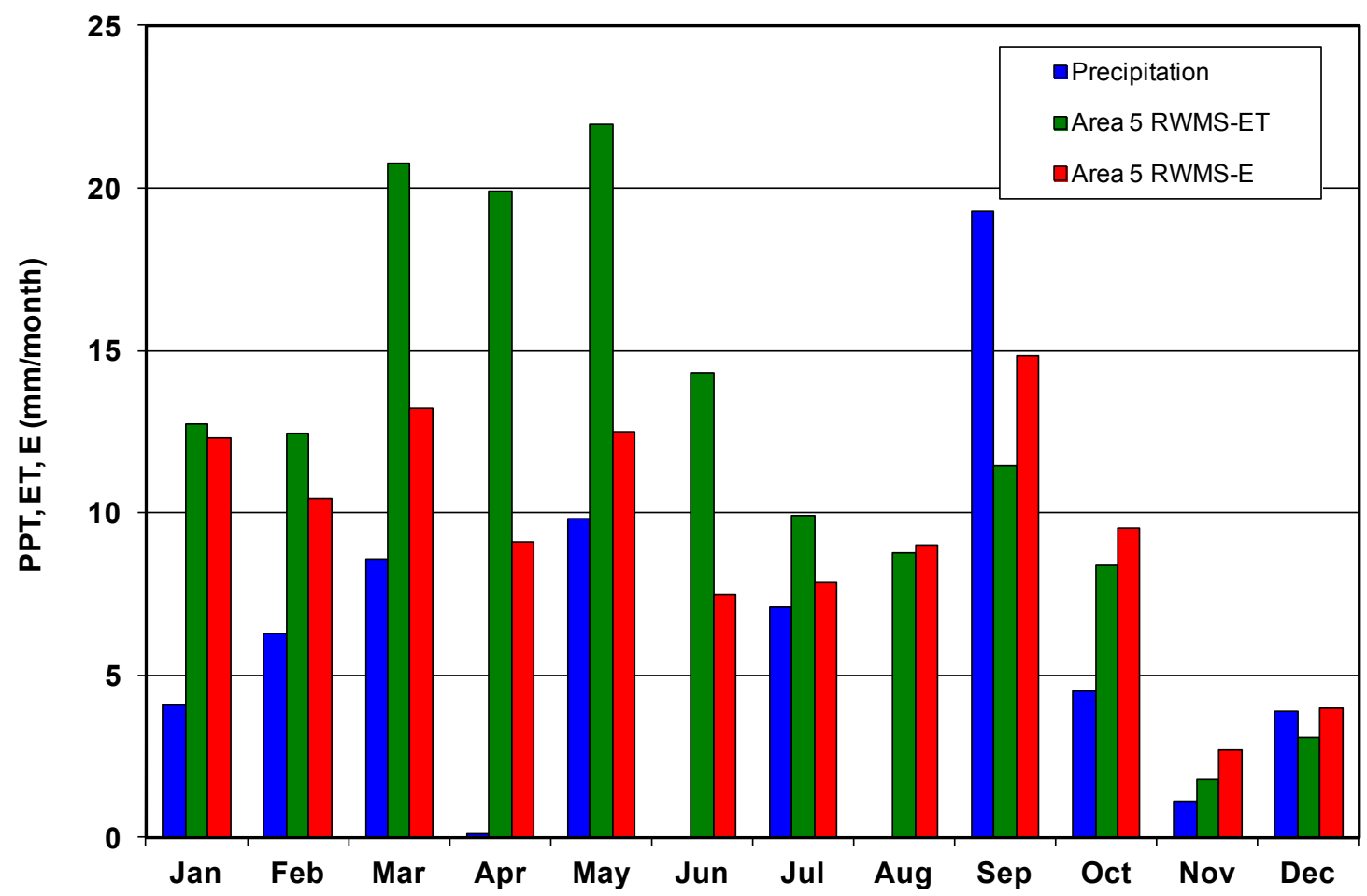

Figure 4-25. Monthly Precipitation, E, and ET during 2011 


\subsubsection{Automated Waste Cover Monitoring System}

Automated vadose monitoring on the operational covers at the Area 5 RWMS was temporarily discontinued during construction of the 92-Acre Area ET cover. New vadose zone moisture sensors were installed in the final ET cover during October 2011 and monitoring was continued.

In December 2000, time-domain reflectometry (TDR) probes were installed in the final vegetated cover of the U-3ax/bl waste disposal unit at the Area 3 RWMS (Figure 3-1). Eight vertically arranged TDR probes were installed at four locations at depths ranging from 30 to $244 \mathrm{~cm}$ ( 1 to $8 \mathrm{ft}$ ). Measured soil water content values for one location (East Nest A) in the U-3ax/bl waste cover are shown in Figure 4-26. From 2001 to 2005, the TDR data indicate that the soil water content in the cover generally decreased over time as the vegetation on the cover grew. The precipitation events beginning in October 2004 infiltrated into the final cover of $\mathrm{U}-3 \mathrm{ax} / \mathrm{bl}$, but the moisture has been removed without percolating below the $244 \mathrm{~cm}$ (8 $\mathrm{ft}$ ) deep sensor. Unlike the bare-soil operational covers on P03, P04, and P05, the moisture at U-3ax/bl was removed by ET before reaching $244 \mathrm{~cm}(8 \mathrm{ft})$. The wetting front from the $6.6 \mathrm{~cm}(2.6 \mathrm{in}$.) precipitation event on September 21 and September 22, 2007, only reached $30 \mathrm{~cm}$ (1 ft) deep as compared to 90 to $120 \mathrm{~cm}$ (3 to $4 \mathrm{ft}$ ) deep in the bare operational covers. Precipitation during January and February 2009 increased water contents to a depth of $30 \mathrm{~cm}$. Precipitation during January and February 2010 increased water contents to a depth of $61 \mathrm{~cm}$. The $8.6 \mathrm{~cm}$ of precipitation from December 18 to 23, 2010, increased water contents in the cover to a depth of $122 \mathrm{~cm}$ by May 2011. This moisture did not percolate to $152 \mathrm{~cm}$ deep. ET removed this moisture from the cover by October 2011.

Initial water contents are lower in the vegetated U-3ax/bl cover, so more moisture is stored per unit depth as the wetting front moves down. Vegetation is critical to the effectiveness of the $\mathrm{U}-3 \mathrm{ax} / \mathrm{bl}$ cover. In the native environment, about $12 \%$ of the surface area is covered by plant material. Obtaining $12 \%$ vegetative cover on the soil caps is dependent upon the seed germination success and seedling survival of native plants seeded or transplanted onto the cover. A quantitative analysis of the vegetative cover on the U-3ax/bl cover is conducted annually in the spring. The percent cover for the established U-3ax/bl cover has ranged from $20.2 \%$ in 2005 , to $19.6 \%$ in 2006 , to $10.6 \%$ in 2007 , to $26.8 \%$ in 2008 , to $12.2 \%$ in 2009 , to $19.8 \%$ in 2010 , to $21.2 \%$ in 2011 . The dominant perennial plant on the U-3ax/bl cover is Atriplex confertifolia (shadscale saltbush), which accounted for $9.0 \%$ cover. 


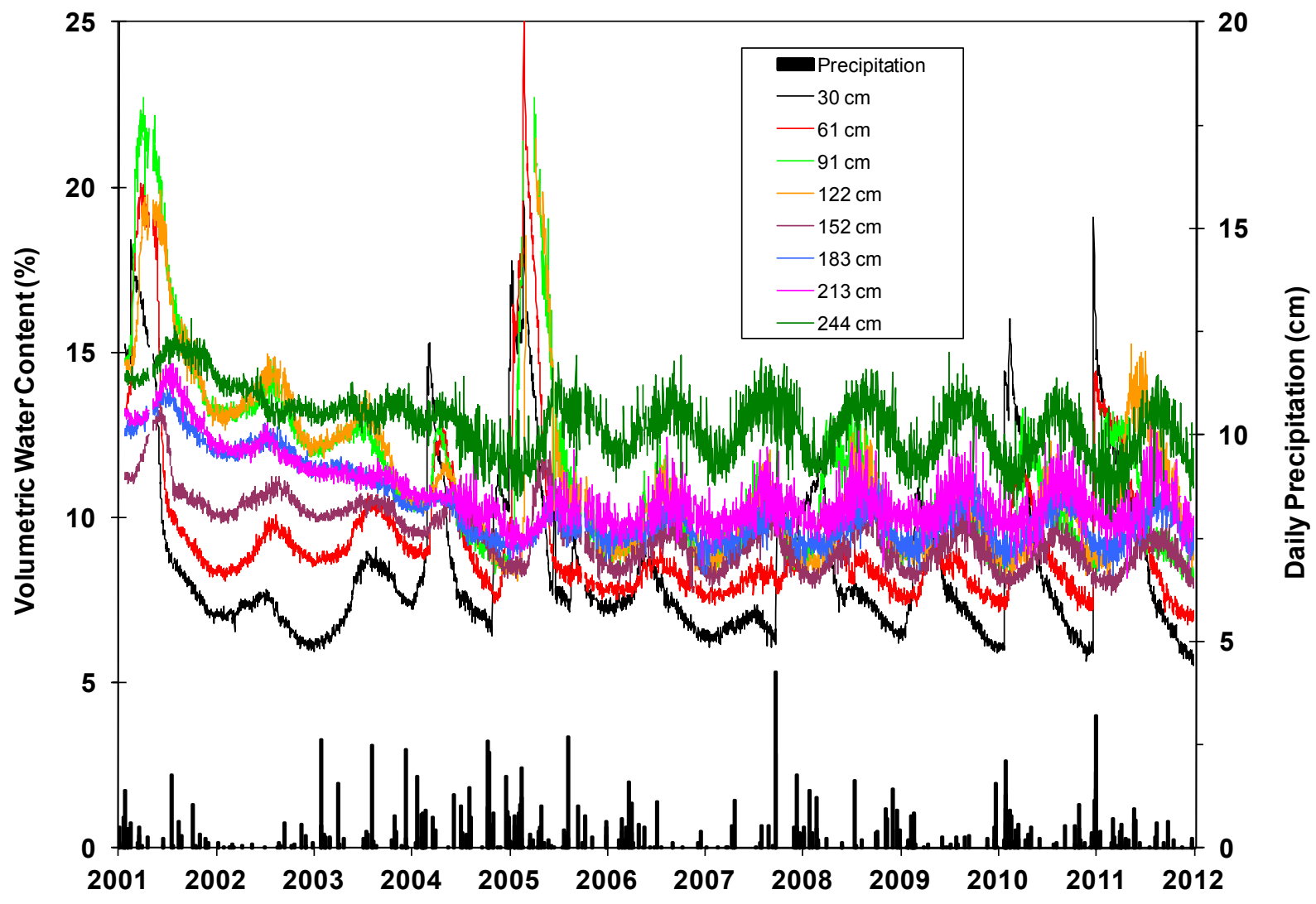

Figure 4-26. Soil Water Content in the U-3ax/bl Cover

\subsubsection{Area 3 Drainage Lysimeter Facility}

The Area 3 Drainage Lysimeter Facility is immediately northwest of the U-3ax/bl waste disposal unit at the Area 3 RWMS (Figure 3-1). This facility is designed to collect saturated gravity

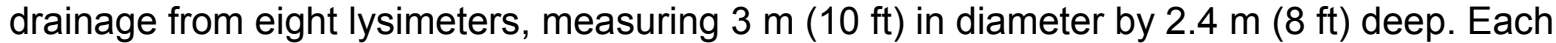
lysimeter is filled with native soil and packed to mimic the U-3ax/bl soil cover. Each lysimeter has eight TDR probes to measure moisture content depth profiles, paired with eight heat dissipation probes to measure soil water potential depth profiles. The probes are installed at $7.6 \mathrm{~cm}(0.25 \mathrm{ft}), 15 \mathrm{~cm}(0.5 \mathrm{ft}), 30 \mathrm{~cm}(1 \mathrm{ft}), 61 \mathrm{~cm}(2 \mathrm{ft}), 91 \mathrm{~cm}(3 \mathrm{ft}), 122 \mathrm{~cm}(4 \mathrm{ft}), 183 \mathrm{~cm}$ $(6 \mathrm{ft})$, and $244 \mathrm{~cm}(8 \mathrm{ft})$ deep. Measured water content values at the bottom of the lysimeters and drainage from the lysimeters provide an indirect measure of potential drainage from the U-3ax/bl soil cover. The lysimeter facility was constructed to fulfill data needs, including reducing uncertainty in the expected performance of monolayer-ET closure covers under various surface vegetation treatments and climatic change scenarios such as increased rainfall.

There are three surface vegetation treatments subject to two climate treatments on the lysimeters. The three surface vegetation treatments are bare-soil, invader species (primarily Bromus tectorum [cheatgrass] and Halogeton glomeratus [halogeton]), and native species (primarily Atriplex confertifolia [shadscale saltbush], Krascheninnikovia lanata [winterfat], Ephedra nevadensis [Nevada jointfir], Achnatherum hymenoides [Indian ricegrass], and Elymus elymoides [squirreltail grass]). The climate treatments are natural precipitation and 3-times natural precipitation. The 3-times natural precipitation lysimeters receive natural precipitation and are irrigated with an amount equal to 2-times natural precipitation. 
The eight lysimeters are identified as Lysimeter A through Lysimeter $\mathrm{H}$. Lysimeter $\mathrm{A}$ is bare soil with natural precipitation, Lysimeter B is bare soil with 3-times natural precipitation, Lysimeter C is invader species with natural precipitation, Lysimeter $D$ is invader species with 3-times natural precipitation, Lysimeters $E$ and $G$ are native species with natural precipitation, and Lysimeters $F$ and $\mathrm{H}$ are native species with 3-times natural precipitation. The 2011 precipitation at the drainage lysimeters is $86 \mathrm{~mm}$ (3.4 in.). The 2011 irrigation applied to Lysimeters $B, D, F$, and $H$ is $171 \mathrm{~mm}$ (6.7 in.). The 2011 lysimeter treatments are summarized in Table 4-2.

There were 1,861 liters (492 gallons) of drainage from Lysimeter B. The equivalent depth of this drainage is $25.5 \mathrm{~cm}$ (10.0 in.) (Table 4-2). Drainage from Lysimeter B occurred from January 1, 2011 , to October 5, 2011. The Lysimeter B drainage is $10 \%$ of total precipitation and applied irrigation. There was no drainage from any other lysimeter during 2011. Drainage has only occurred from the irrigated lysimeters. Total cumulative drainage from each irrigated lysimeter is $141.6 \mathrm{~cm}$ (55.7 in.) from Lysimeter B, $6.5 \mathrm{~cm}$ (2.6 in.) from Lysimeter D, $29.3 \mathrm{~cm}$ (11.5 in.) from Lysimeter $F$, and $12.3 \mathrm{~cm}$ (4.8 in.) from Lysimeter $\mathrm{H}$ (Figure 4-27).

Table 4-2. Area 3 Drainage Lysimeter Treatments in 2011

\begin{tabular}{||clcccl||}
\hline \hline Lysimeter & \multicolumn{1}{c}{ Climate } & $\begin{array}{c}\text { Precipitation } \\
(\mathrm{mm})\end{array}$ & $\begin{array}{c}\text { Irrigation } \\
(\mathrm{mm})\end{array}$ & $\begin{array}{c}\text { Drainage } \\
(\mathrm{mm})\end{array}$ & Surface Vegetation \\
\hline A & Natural precipitation & 86 & 0 & 0 & Bare-soil \\
B & 3-times natural precipitation & 86 & 171 & 26 & Bare-soil \\
C & Natural precipitation & 86 & 0 & 0 & Invader species \\
D & 3-times natural precipitation & 86 & 171 & 0 & Invader species \\
E & Natural precipitation & 86 & 0 & 0 & Native species \\
F & 3-times natural precipitation & 86 & 171 & 0 & Native species \\
G & Natural precipitation & 86 & 0 & 0 & Native species \\
H & 3-times natural precipitation & 86 & 171 & 0 & Native species \\
\hline \hline
\end{tabular}




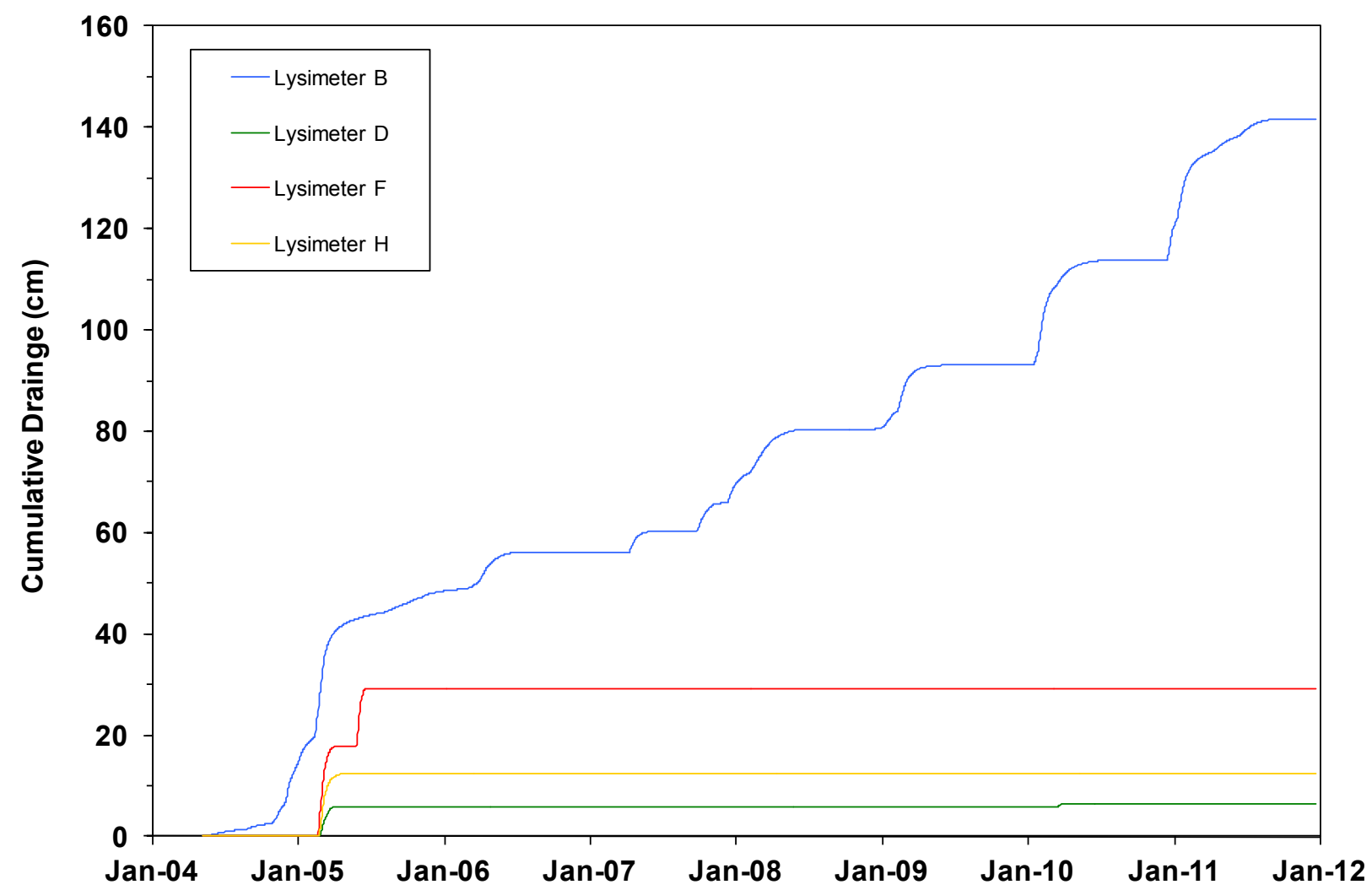

Figure 4-27. Cumulative Drainage from the Drainage Lysimeters

Cover was measured for each of the eight drainage lysimeters on May 5, 2011. The results are summarized in Table 4-3. B. tectorum accounts for $80.0 \%$ cover on Lysimeter D. Dead $B$. tectorum accounts for much of the litter percent cover.

Table 4-3. Area 3 Drainage Lysimeter Percent Cover

\begin{tabular}{||ccccc||}
\hline Lysimeter & $\begin{array}{c}\text { Plant Cover } \\
\text { (percent) }\end{array}$ & $\begin{array}{c}\text { Bare } \\
\text { (percent) }\end{array}$ & $\begin{array}{c}\text { Gravel } \\
\text { (percent) }\end{array}$ & $\begin{array}{c}\text { Litter } \\
\text { (percent) }\end{array}$ \\
\hline A & 0.0 & 20.0 & 80.0 & 0.0 \\
B & 0.0 & 20.0 & 65.0 & 15.0 \\
C & 55.0 & 22.5 & 5.0 & 17.5 \\
D & 80.0 & 0.0 & 0.0 & 20.0 \\
E & 90.0 & 0.0 & 0.0 & 10.0 \\
F & 55.0 & 0.0 & 0.0 & 45.0 \\
G & 97.5 & 0.0 & 2.5 & 0.0 \\
H & 75.0 & 0.0 & 15.0 & 10.0 \\
\hline \hline
\end{tabular}


Figure 4-28 shows the total water storage for all eight lysimeters from 2004 through 2011. Water storage is calculated using TDR data. The two bare-soil lysimeters (Lysimeters A and B) have the highest water storage. Evaporation and drainage are the only processes that remove water from these two lysimeters. Water storage in the other irrigated lysimeters (Lysimeters D, F, and $\mathrm{H}$ ) was elevated at the beginning of 2011. ET removed most of this water in the spring and summer.

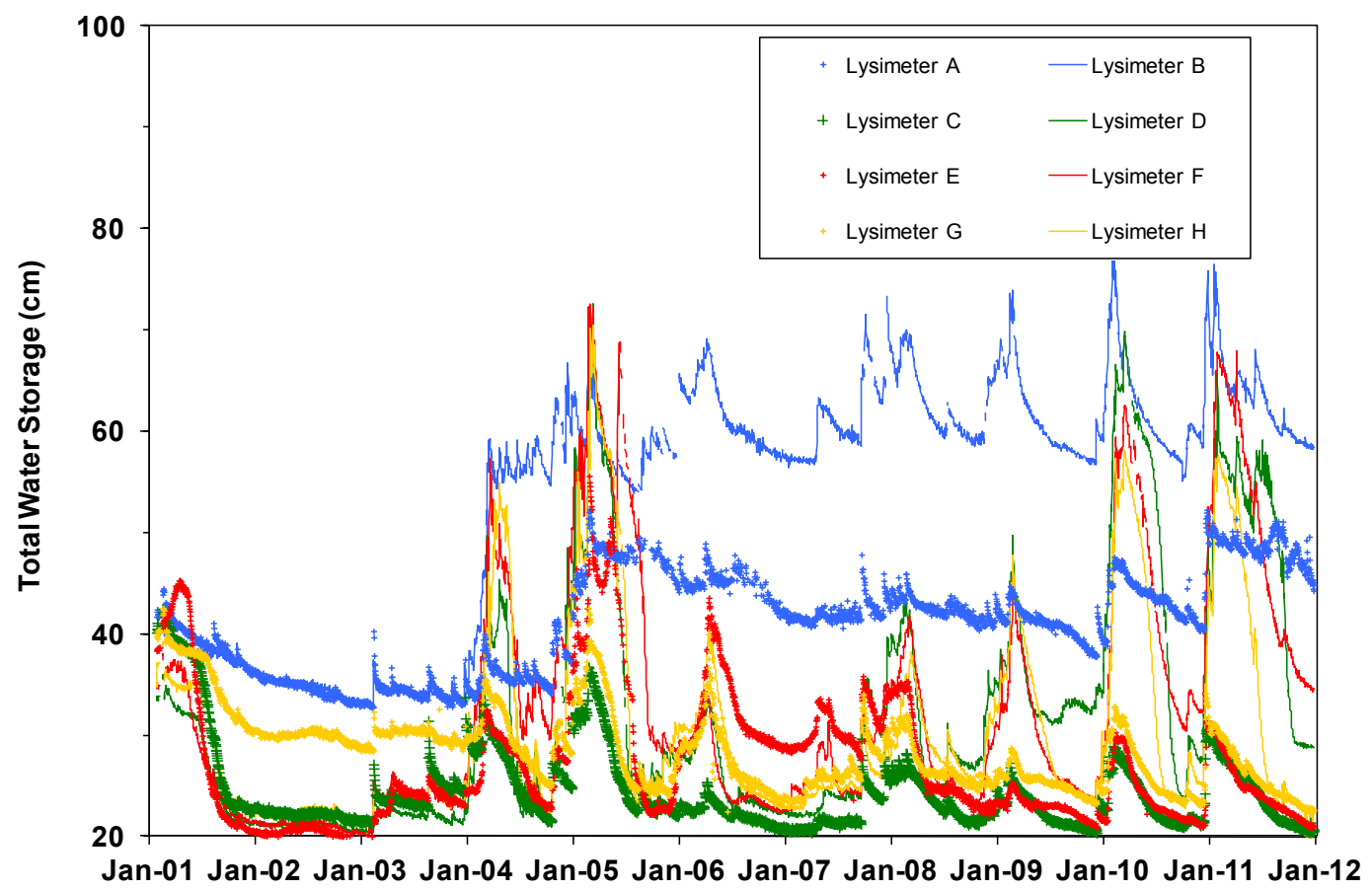

Figure 4-28. Soil Water Storage in the Drainage Lysimeters

\subsection{WASTE COVER SUBSIDENCE}

Subsidence monitoring is conducted to ensure that subsidence features are repaired to prevent the development of preferential water migration pathways through the waste covers. Subsidence monitoring also helps ensure that vadose zone monitoring data are representative of the entire RWMS. Typically as small depressions or cracks are observed in the covers, they are filled before large subsidence features develop. No large subsidence features were observed during 2011.

\subsection{BIOTA MONITORING DATA}

No biota monitoring data was collected during 2011. 


\subsection{CONCLUSION}

The 2011 environmental and operational monitoring data from the Area 3 and Area 5 RWMSs indicate that these facilities are performing as expected for the long-term isolation of buried waste. Direct radiation exposure data indicate a rate that is well below any dose of concern, and air monitoring data indicate that concentrations of radioactive materials in air remain below any concentrations of concern. Groundwater and vadose zone monitoring data indicate that the groundwater beneath the Area 5 RWMS is unaffected by the waste disposal operations. Vadose zone monitoring data indicate that vegetation prevents infiltrating precipitation from percolating deep into the soil by returning the moisture to the atmosphere by ET. Long-term vadose zone monitoring data from the weighing lysimeters indicate no drainage through the bottoms of the vegetated lysimeters. All 2011 monitoring data indicate that the Area 3 and Area 5 RWMSs are performing within expectations of the model and parameter assumptions for the facility PAs. 
THIS PAGE INTENTIONALLY LEFT BLANK 


\subsection{REFERENCES}

Air Resources Laboratory, Special Operations and Research Division, 2012. NOAA Air Resources Laboratory. http://www.sord.nv.doe.gov. [Accessed June 18, 2012].

Allen, R. G., I. A. Walter, R. L. Elliot, T. A. Howell, D. Itenfisu, M. E. Jensen, and R. L. Snyder, 2005. The ASCE Standardized Reference Evapotranspiration Equation. American Society of Civil Engineers.

ARL/SORD, see Air Resources Laboratory, Special Operations and Research Division.

Bechtel Nevada, 1998. Hydrogeologic Characterization of the Unsaturated Zone at the Area 3 Radioactive Waste Management Site. Volume 1: "Data Interpretations." Volume 2: "Data." DOE/NV/11718--210. February 1998.

Bechtel Nevada, 2001. Closure Report for Corrective Action Unit 110: Area 3 RWMS U-3ax/bl Disposal Unit, Nevada Test Site, Nevada. DOE/NV/11718--743. June 2001.

Bechtel Nevada, 2003. Nevada Test Site Routine Radiological Environmental Monitoring Plan. DOE/NV/11718--804. Bechtel Nevada. June 2003.

Bechtel Nevada, 2005a. Site Characterization and Monitoring Data from Area 5 Pilot Wells. DOE/NV/11718--1067. September 2005.

Bechtel Nevada, 2005b. Site Characterization Data from the U-3ax/b/ Exploratory Boreholes. DOE/NV/11718--003-Rev1. Bechtel Nevada. August 2005.

Bechtel Nevada, 2005c. Integrated Closure and Monitoring Plan for the Area 3 and Area 5 Radioactive Waste Management Sites at the Nevada Test Site. DOE/NV/11718--449 REV2. June 2005.

Bechtel Nevada, 2006. Characterization Report for the 92-Acre Area of the Area 5 Radioactive Waste Management Site, Nevada Test Site, Nevada. DOE/NV/11718--1154. June 2006.

Blout, D. O., W. S. Birchfiel, D. P. Hammermeister, K. A. Zukosky, and K. D. Donnelson, 1995. Site Characterization Data from Area 5 Science Boreholes, NTS, Nye County, Nevada. DOE/NV/11432--170. Reynolds Electrical \& Engineering Co., Inc. February 1995.

BN, see Bechtel Nevada.

Bolsunovsky, A., and D. Dementyev, 2011. "Evidence of the Radioactive Fallout in the Center of Asia (Russia) following the Fukushima Nuclear Accident." Journal of Environmental Radioactivity, Vol. 102, No. 11, pp. 1062-1064.

Campbell, G. S., 1977. An Introduction to Environmental Biophysics. Heidelberg Science Library. Springer-Verlag, New York.

Carvalho, F. P., M. C. Reis, J. M. Oliveira, M. Malta, and L. Silva. In Press. Radioactivity from Fukushima Nuclear Accident Detected in Lisbon, Portugal. Journal of Environmental Radioactivity. http://www.sciencedirect.com/science/article/pii/S0265931X12000707. [Accessed May 7, 2102]. 
Cochran, J. R., W. E. Beyeler, D. A. Brosseau, L. H. Brush, T. J. Brown, B. Crowe, S. H. Conrad, P. A. Davis, T. Ehrhorn, T. Feeney, B. Fogleman, D. P. Gallegos, R. Haaker, D. Kalinina, L. L. Price, D. P. Thomas, and S. Wirth, 2001. Compliance Assessment Document for the Transuranic Wastes in the Greater Confinement Disposal Boreholes at the Nevada Test Site. Sandia Report SAND2001-2977. Sandia National Laboratories. September 2001.

Community Environmental Monitoring Program, 2011. CEMP Air Monitoring in Response to the Fukushima Nuclear Power Plant Accident. http://www.cemp.dri.edu/japan response.html. [Accessed May 7, 2012].

Delphi and Cesare, see The Delphi Groupe and J. A. Cesare and Associates.

Desotell, L. T., D. B. Hudson, V. Yucel, and J. T. Carilli, 2006. "Use of Long-Term Lysimeter Data in Support of Shallow Land Waste Disposal Cover Design." In: Proceedings of the Waste Management '06 Conference. February 26-March 2, 2006. Tucson, Arizona.

Desotell, L. T., D. B. Hudson, D. Anderson, V. Yucel, G. Shott, G. L. Pyles, and J. T. Carilli, 2007. "Performance of Evapotranspirative Covers under Enhanced Precipitation: Preliminary Data." In: Proceedings of the Waste Management '07 Conference. February 26-March 1, 2007. Tucson, Arizona.

Doorenbos, J., and W. O. Pruitt, 1977. Guidelines for Predicting Crop Water Requirements. FAO Irrigation and Drainage Paper No. 24, 2d ed. U.N. Food and Agricultural Organization. Rome, Italy.

EPA, see U.S. Environmental Protection Agency.

Goodrich, J. G., 2010. Design of Revisions to the Evapotranspiration Cover for the 92-Acre Area: Area 5 Waste Management Division Retired Mixed Waste Pits Nevada National Security Site, Nevada. October 2010.

Institute of Nuclear Power Operations, 2011. Special Report on the Nuclear Accident at the Fukushima Daiichi Nuclear Power Station. INPO 11-005. Institute of Nuclear Power Operations, Atlanta, GA.

Leon, J. D., D. A. Jaffe, J. Kaspar, A. Knecht, M. L. Miller, R. G. H. Robertson, and A. G. Schubert, 2011. "Arrival Time and Magnitude of Airborne Fission Products from the Fukushima, Japan, Reactor Incident as Measured in Seattle, WA, USA." Journal of Environmental Radioactivity, Vol. 102, No. 11, pp. 1032-1038.

Levitt, D. G., and V. Yucel, 2002. "Potential Groundwater Recharge and the Effects of Soil Heterogeneity on Flow at Two Radioactive Waste Management Sites at the Nevada Test Site." In: Proceedings of the 2002 International Groundwater Symposium. March 25-28, 2002. Berkeley, California.

Levitt, D. G., M. J. Sully, B. L. Dozier, and C. F. Lohrstorfer, 1999. "Determining the Performance of an Arid Zone Radioactive Waste Site through Site Characterization, Modeling, and Monitoring." In: Proceedings of the Waste Management '99 Conference. February 28-March 4, 1999. Tucson, Arizona. 
National Security Technologies, LLC, 2007. Characterization Report Area 3 Radioactive Waste Management Site Nevada Test Site, Nevada. DOE/NV/25946--080. March 2007.

National Security Technologies, LLC, 2008. Closure Plan for the Area 5 Radioactive Waste Management Site at the Nevada Test Site. DOE/NV/25946--553. September 2008.

National Security Technologies, LLC, 2011. Nevada Test Site Environmental Report 2010. DOE/NV/25946--1305. September 2011.

National Security Technologies, LLC, 2012a. National Emission Standards for Hazardous Air Pollutants-Radionuclide Emissions, Calendar Year 2011. DOE/NV/25946--1530. June 2012.

National Security Technologies, LLC, 2012b. Nevada National Security Site 2011 Data Report: Groundwater Monitoring Program, Area 5 Radioactive Waste Management Site. DOE/NV/25946--1415. February 2012.

NNSA/NSO, see U.S. Department of Energy, National Nuclear Security Administration Nevada Site Office

NSTec, see National Security Technologies, LLC.

Plannerer, H. N., 1996. Siting Criteria for Angle Drilling Under the U-3ah/at Disposal Unit. Los Alamos National Laboratory Report LA-UR-96-1679. May 13, 1996.

Reynolds Electrical \& Engineering Co., Inc., 1993a. Hydrogeologic Data for Existing Excavations at the Area 5 RWMS, Nevada Test Site, Nye County, Nevada. DOE/NV/11432--40. December 1993.

Reynolds Electrical \& Engineering Co., Inc., 1993b. Hydrogeologic Data for Science Trench Boreholes at the Area 5 RWMS, Nevada Test Site, Nye County, Nevada. December 1993.

Shott, G. J., V. Yucel, M. J. Sully, L. E. Barker, S. E. Rawlinson, and B. A. Moore, 1997. Performance Assessment/Composite Analysis for the Area 3 Radioactive Waste Management Site at the Nevada Test Site, Nye County, Nevada. Revision 2.1. DOE/NV--491-REV 2.1. Bechtel Nevada. September 1997.

Shott, G. J., L. E. Barker, S. E. Rawlinson, M. J. Sully, and B. A. Moore, 1998. Performance Assessment for the Area 5 Radioactive Waste Management Site at the Nevada Test Site, Nye County, Nevada. Revision 2.1. DOE/NV/11718--176. Bechtel Nevada. January 1998.

Soule, D. A., 2006. Climatology of the Nevada Test Site. Air Resources Laboratory, Special Operations and Research Division 2006-03. April 2006.

Snyder, K. E., R. D. Van Remortel, D. L. Gustafson, H. E. Huckins-Gang, J. J. Miller, S. E. Rawlinson, and S. M. Parsons, 1995. Surficial Geology and Landscape Development in Northern Frenchman Flat, Interim Summary and Soil Data Report. DOE/NV/25946--466. Raytheon Services Nevada. September 1995. 
Thakur, P., S. Ballard, and R. Nelson, 2012. "Radioactive Fallout in the United States due to the Fukushima Nuclear Plant Accident." Journal of Environmental Monitoring, Vol. 5, No. 14, pp. 1317-1324.

The Delphi Groupe and J. A. Cesare and Associates, 2012. Evapotranspiration Cover for the 92-Acre Area Retired Mixed Waste Pits, Area 5 Waste Management Division, Nevada National Security Site, Final CQA Report. DOE/NV/25946--1428, January 2012.

Tyler, S. W., J. B. Chapman, S. H. Conrad, D. P. Hammermeister, D. O. Blout, J. J. Miller, M. J. Sully, and J. M. Ginanni, 1996. "Soil-Water Flux in the Southern Great Basin, United States: Temporal and Spatial Variations over the Last 120,000 Years." Water Resources Research. Vol. 32, No. 6, pp. 1481-1499.

U.S. Department of Energy, National Nuclear Security Administration Nevada Site Office, 2010. Corrective Action Decision Document/Corrective Action Plan for the 92-Acre Area and Corrective Action Unit 111: Area 5 WMD Retired Mixed Waste Pits, Nevada National Security Site, Nevada. DOE/NV--1326-REV1. November 2010.

U.S. Department of Energy, National Nuclear Security Administration Nevada Site Office, 2012. Closure Report for the 92-Acre Area and Corrective Action Unit 111: Area 5 WMD Retired Mixed Waste Pits, Nevada National Security Site, Nevada. DOE/NV--1472. February 2012.

U.S. Environmental Protection Agency, 2011. Japanese Nuclear Emergency: EPA's Radiation Monitoring. http://www.epa.gov/japan2011. [Accessed May 7, 2012]. 


\section{DISTRIBUTION LIST}

\section{U.S. Department of Energy}

Jhon T. Carilli

LLW Federal Sub-Project Director, Waste Management Project

U.S. Department of Energy

National Nuclear Security Administration

Nevada Site Office

P.O. Box 98518 M/S 505

Las Vegas, NV 89193-8518

Kenneth M. Small

RCRA Program Manager, Waste Management Project

U.S. Department of Energy

National Nuclear Security Administration

Nevada Site Office

P.O. Box 98518 M/S 505

Las Vegas, NV 89193-8518

U.S. Department of Energy

National Nuclear Security Administration

Nevada Site Office

Public Reading Facility

c/o Nuclear Testing Archive

P.O. Box 98521, M/S 400

Las Vegas, NV 89193-8521

U.S. Department of Energy

National Nuclear Security Administration

Nevada Site Office

Technical Library

P.O. Box 98518, M/S 505

Las Vegas, NV 89193-8518

U.S. Department of Energy

Office of Scientific and Technical Information

P.O. Box 62

Oak Ridge, TN 37831-0062
Copies

4

1

2 (CD)

$1(\mathrm{CD})$

1 digital file 
$\underline{\text { National Security Technologies, LLC }}$

David B. Hudson

National Security Technologies, LLC

P.O. Box $98521, \mathrm{M} / \mathrm{S}$ NLV083

Las Vegas, NV 89193-8521

Stevon A. Rainey

National Security Technologies, LLC

P.O. Box 98521, M/S NNSS273

Las Vegas, NV 89193-8521

Theodore J. Redding

National Security Technologies, LLC

P.O. Box $98521, \mathrm{M} / \mathrm{S}$ NNSS273

Las Vegas, NV 89193-8521

Gregory J. Shott

National Security Technologies, LLC

P.O. Box 98521, M/S NLV083

Las Vegas, NV 89193-8521

Ronald W. Warren

1

National Security Technologies, LLC

P.O. Box 98521, M/S NNSS273

Las Vegas, NV 89193-8521

Vefa Yucel

National Security Technologies, LLC

P.O. Box 98521, M/S NLV083

Las Vegas, NV 89193-8521 